\title{
Structural geology and basin development of the Norwegian Sea
}

\author{
Roald B. Færseth ${ }^{1}$ \\ ${ }^{1}$ Ryenbergveien 75A, 0677 Oslo, Norway \\ E-mail corresponding author (Roald B. Færseth): roaldf@broadpark.no
}

\author{
Keywords: \\ - Norwegian Sea \\ continental margin \\ - Post-Caledonian \\ structures \\ - Basin development and \\ sedimentation
}

Received:

12. February 2020

Accepted:

15. October 2020

Published online:

5. February 2021
The investigated area comprises the 300-500 km-wide passive margin offshore Mid Norway as well as the 70-40 km-wide margin northwest of the Lofoten-Vesterålen archipelago. Following the Caledonian Orogeny, Greenland was close to Mid Norway and central-northern Norway. The orogeny climaxed with the Early Devonian continent collision with subduction of the Baltic craton beneath Laurentia, and a mountain range several kilometres high evolved. The mountain range remained a positive topographic element throughout the Late Palaeozoic and Early Mesozoic. Non-marine Carboniferous sediments were deposited onshore East Greenland, but there is no evidence of sedimentation during this period offshore Mid Norway. Three significant rift episodes, i.e., Late Permian-Early Triassic, Middle-Late Jurassic and Campanian-Paleocene are evident, with intervening (c. $70 \mathrm{Ma}$ ) periods of overall tectonic quiescence. Permo-Triassic sediments, 4000-6000 $\mathrm{m}$ in thickness, were deposited in an eastern basin area juxtaposed against basement across large normal faults close to the Norwegian mainland. The topography created by the Late Permian-Early Triassic rift episode became levelled during the Middle Triassic, and younger sediments were deposited over a relatively flat area represented by the present Trøndelag Platform and the Halten and Dønna terraces. Due to Jurassic extension there was a change to a setting where the Halten and Dønna terraces became separate structural entities, down-faulted and with a complex basin-floor topography. Until the climax stage of the Jurassic rift episode, the Caledonian mountain range might have occupied the area between the Halten Terrace and Liverpool Land, at the east coast of Greenland. The subaerially exposed land mass was eroded and acted as an important sediment source. Middle and Lower Jurassic, but also Triassic sediments entering into the basin from the west contain conglomerates and pebbly sandstones deposited under fluvial, deltaic and marginal marine conditions, and clinoforms are recorded along the basin margin on the western Halten Terrace. The largescale paleogeography was a central basement high, which separated the basin onshore East Greenland and the basin area offshore Mid Norway. Due to erosion and accelerated Late Jurassic rifting the basement high ceased to exist as a source area, leaving the narrow Sklinna Ridge as an easternmost remnant in the footwall of the Klakk Fault Complex. This stage of development is regarded as the first indication of a large and continuous marine basin between Mid Norway and Greenland after the Caledonian Orogeny.

Færseth, R.B. 2020: Structural geology and basin development of the Norwegian Sea. Norwegian Journal of Geology 100, 202018. https://dx.doi.org/10.17850/njg100-4-1.

This work is licensed under a Creative Commons Attribution 4.0 International License. 


\section{Introduction}

The investigated area covers the continental shelf offshore Norway, roughly between $62^{\circ}$ and $69^{\circ} \mathrm{N}$ (Fig. 1). Being a prolific hydrocarbon province, the area has received a lot of attention after the first licences allocated on Haltenbanken in 1980 and the first major discovery the following year. The narrow Lofoten-Vesterålen shelf, which represents the northeastern part of the investigated area, is not yet open to petroleum exploration and accordingly no commercial wells have been drilled.

Regarding petroleum geology, the shelf offshore Mid Norway represents two contrasting areas. To the east, the Halten and Dønna terraces (Fig. 1) soon became the focus of exploration, where most proven reserves are located. The Halten Terrace is hosting more than a dozen oil, condensate and gas fields, of which 7-8 classify as giants producing from Jurassic sandstone reservoirs. In the area occupied by the Cretaceous Møre and Vøring basins, Jurassic sediments became deeply buried, and main targets are structural traps with Paleocene-Campanian sandstones as potential reservoirs. However, at present the giant Ormen Lange gas/condensate field, found in 1997, is the only commercial discovery. This field, producing from Paleocene sandstone, is located in the Møre Basin above the Ormen Lange Dome (Fig. 1).

Based on plate reconstructions (e.g., Mosar et al., 2002; Torsvik \& Cocks, 2005), Greenland was close to Mid Norway and central-northern Norway after the final Late Silurian-Early Devonian Scandian phase of the Caledonian Orogeny (e.g., Roberts \& Gee, 1985). Due to collision of the Baltic craton with Laurentia, a mountain range several kilometres high evolved (e.g., Andersen \& Jamtveit, 1990).

Metamorphosed rocks of the mountain range became the substrate for Late Palaeozoic to Early Mesozoic deposits and acted as an important sediment source.

The post-Caledonian geological development reflects highly variable tectonic, paleogeographic and climatic conditions as well as sea-level changes. Broad overviews of the North Atlantic geological development from the Late Palaeozoic to the present have been published (Rønnevik \& Navrestad, 1976, 1977; Jørgensen \& Navrestad, 1981; Bøen et al., 1984; Gage \& Doré, 1986; Brekke \& Riis, 1987; Larsen, 1987; Ziegler, 1988, 1989, 1990; Swiecicki et al., 1998; Roberts et al., 1999; Brekke, 2000; Stemmerik, 2000; Brekkeetal., 2001). After these regional studies, published two to four decades ago, a large number of wells have been drilled in the area under consideration, seismic data have improved and numerous studies addressing various geological aspects have been published. As debated below, publications present conflicting paleogeographic models as well as differing views on the timing and mechanisms behind suggested structural events.

Over the years, long-offset seismic reflection profiles have been acquired over the Mid Norwegian shelf, with recorded depths of 10 and 12 seconds TWT, and profiles have been applied in attempts to unravel deep-seated features beneath the Møre and Vøring basins. A whole host of publications, referred to below, have addressed the development of deep structures, crustal stretching with local hyperextension, crustal architecture, underplating, mantle exhumation and magmatism. As the base Cretaceous may be as deep as 15-17 km in some of the sub-basins (e.g., Osmundsen et al., 2016), problems arise with the interpretation of structures and lithologies at depth. However, deep-seated features beneath the Møre and Vøring basins are not a main topic of the present contribution.

This paper describes how major post-Caledonian structural elements evolved during major episodes of deformation, and how these structures have influenced the basin physiography, depositional environment and sediment distribution. Within the investigated area, the gross-scale structure changes significantly, from the wide shelf offshore Mid Norway to the narrow Lofoten-Vesterålen margin. However, this study documents that the eastern part of the Norwegian Sea shares fundamental structural and sedimentological characteristics along strike. 


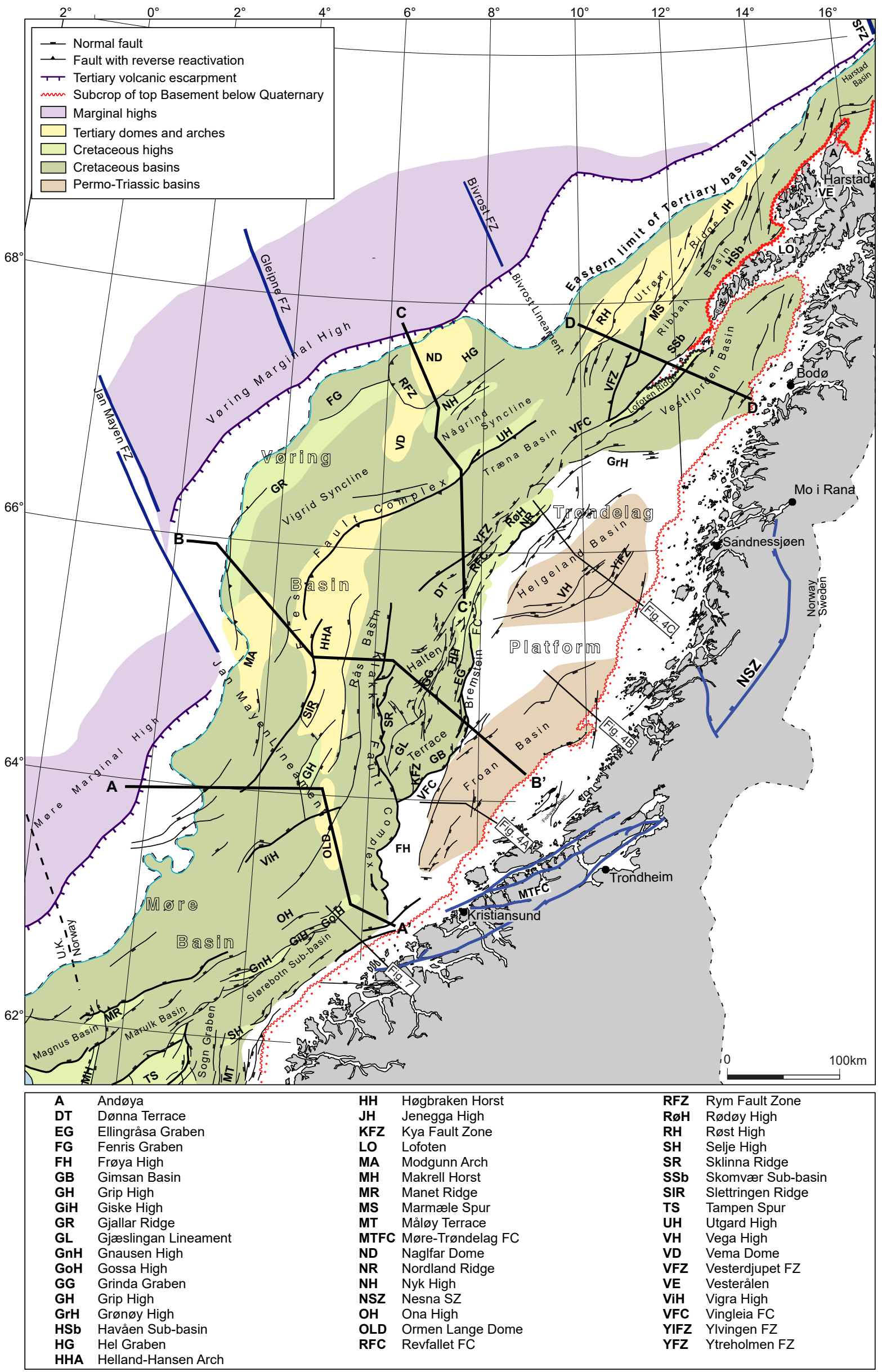

Figure 1. Principal structural elements of the Norwegian Sea. Slightly modified from Blystad et al., (1995). 


\section{Geological framework}

Although comprising numerous structural elements (Fig. 1), the study area encompasses five major structural provinces; the Møre Basin, Vøring Basin, Halten/Dønna terraces, Trøndelag Platform and the shelf offshore Lofoten-Vesterålen. In the area, some 350 million years separate two important platetectonic events, namely the Caledonian Orogeny and the breakup of the North Atlantic Ocean. During the intervening period, late- to post-Caledonian extensional collapse in the Devonian (e.g., Fossen, 1992; Braathen et al., 2000, 2002; Osmundsen \& Andersen, 2001; Olesen et al., 2002) was succeeded by periods of rifting, which affected the North Atlantic region from the Carboniferous and culminated with crustal separation between Greenland and Eurasia at the Paleocene-Eocene boundary (Bukovics et al., 1984; Gabrielsen et al., 1984; Bukovics \& Ziegler, 1985; Ziegler, 1988, 1989, 1990; Eldholm et al., 1989; Surlyk, 1990; Blystad et al., 1995; Swiecicki et al., 1998; Doré et al., 1999; Brekke, 2000; Brekke et al., 2001; Færseth \& Lien, 2002; Hartz et al., 2002; Ren et al., 2003; Gernigon et al., 2004; Hamann et al., 2005; Faleide et al., 2008).

In the investigated area, three significant rift episodes are evident, characterised by large-magnitude basement-involved faulting and significant crustal thinning. The rift episodes in the Late Permian-Early Triassic, Middle-Late Jurassic and Campanian-Paleocene are separated by c. 70 million year periods of overall tectonic quiescence. Episodes of crustal stretching resulted in the $300-500 \mathrm{~km}$-wide margins of the Møre and Vøring basins, respectively (Fig. 1). During the successive rift episodes, the locus of maximum extension migrated in a westerly direction towards the zone of the future continent breakup (e.g., Lundin \& Doré, 1997; Doré et al., 1999; Osmundsen \& Ebbing, 2008; Péron-Pinvidic et al., 2013). A similar, but eastward migration towards the zone of breakup has been described from onshore East Greenland (Voss \& Jokat, 2009).

A model of rifted margins (Péron-Pinvidic et al., 2013), was applied for the Mid-Norwegian shelf by Osmundsen \& Péron-Pinvidic (2018). They divided the area into five domains of differing internal structure and morphology, i.e., the proximal, necking, distal, outer and oceanic domains, bounded by large-magnitude faults, which they defined as breakaway complexes. The eastern part of the proximal domain is located onshore Mid Norway, bounded to the east by the innermost boundary fault system as defined by Mosar et al., (2002) and Mosar, (2003), where the crust is 38-40 km thick (e.g., Olesen et al., $2002,2010)$. In the offshore area, the proximal domain represents a deep, pre-Jurassic basin area with kilometres-thick Triassic and older infill beneath the Trøndelag Platform.

Necking domains comprise the Slørebotn Sub-basin and Gossa High of the Møre margin and the Halten and Dønna terraces of the Vøring margin, respectively (Fig. 2). The Outer necking breakaway complex defines the boundary to the distal domain. Associated with this boundary, crustal thinning is very pronounced with a change of slope in the rising Moho.

As the Vøring margin preserves a much broader outer domain than the one preserved in the Møre Basin (Fig. 1), it has been speculated that this is consistent with parts of the outer Møre margin that became separated from the Norwegian margin in the continent breakup process. As the result of tectonic separation, this margin fragment might be preserved in the Jan Mayen microplate (Péron-Pinvidic et al., 2012; Péron-Pinvidic \& Osmundsen, 2018).

Thick Cretaceous sediment successions define the Møre and Vøring basins (Fig. 2), and due to lack of well control, some controversy exists regarding the depth to the base Cretaceous beneath these basins. Apart from basement highs, apparently capped by Cretaceous sediments, the age and composition of rocks beneath the base Cretaceous remains speculative (e.g., Skogseid \& Eldholm, 1989; Blystad et al., 1995; Swieciki et al., 1998; Doré et al., 1999; Brekke, 2000; Reemst \& Cloetingh, 2000; Skogseid et al., 2000; 

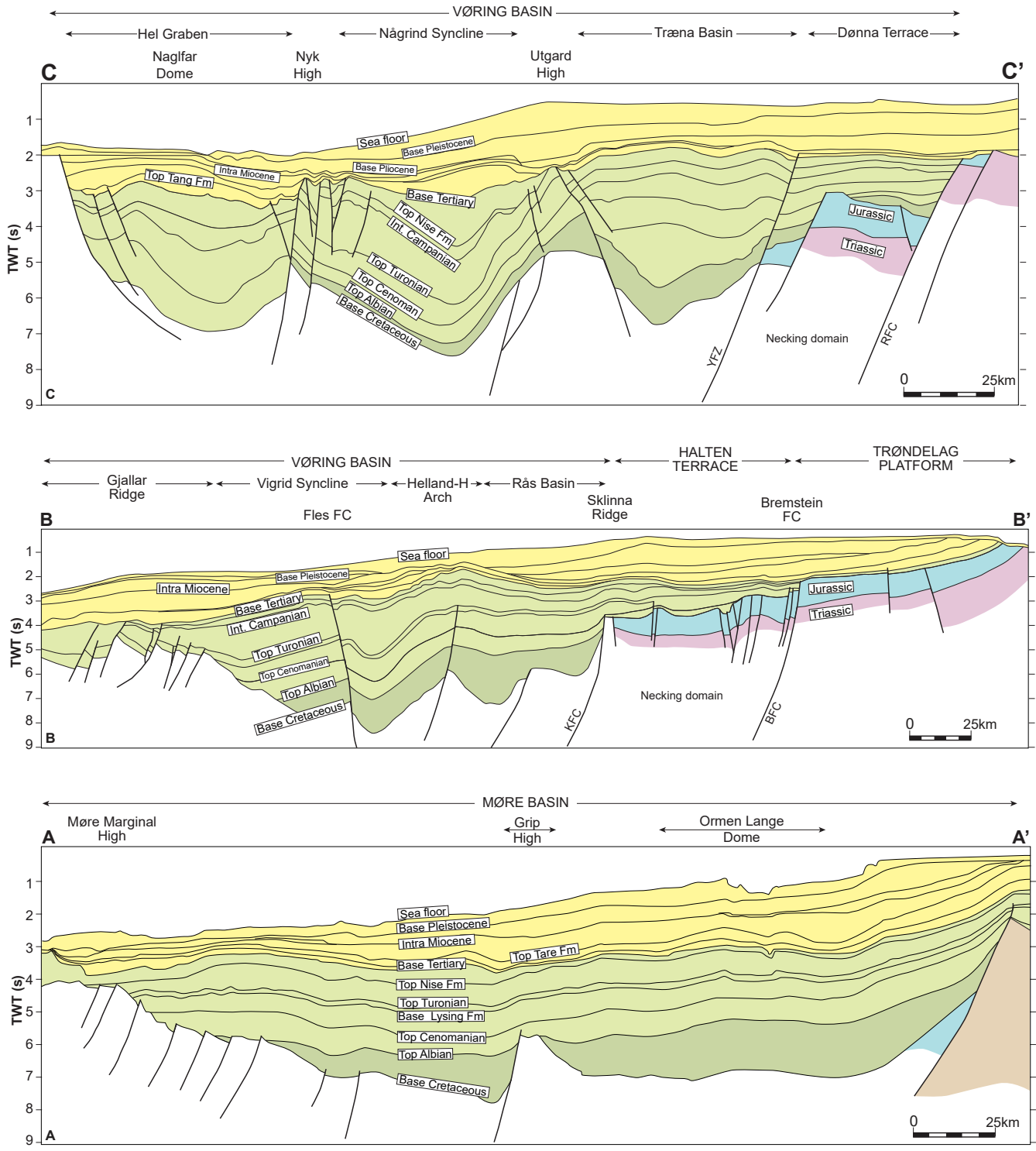

Figure 2. Regional geoseismic profiles illustrate a number of structural elements of the Norwegian Sea. Location of profiles in Fig. 1. The dating of mapped Cretaceous reflectors in the Møre and Vøring basins was based on Norsk Hydros in house interpretation (Færseth \& Lien, 2002). In the Vøring margin the Necking domain, as defined by Osmundsen \& Péron-Pinvidic (2018), is represented by the Halten and Dønna terraces. Major fault zones, which bound the terraces (profiles $B-B^{\prime}$ and $C-C^{\prime}$ ) represent the Inner and Outer breakaway complexes, respectively. The main Møre margin fault, as part of the Møre-Trøndelag Fault Complex, represents the Inner breakaway complex (profile A-A') and bounds the necking domain of the Møre margin to the southeast.

Osmundsen et al., 2002, 2016; Færseth \& Lien, 2002). The northwestern part of the Møre and Vøring basins is dominated by extrusions of basaltic lavas (Fig. 1) and extensive sill intrusion into the Cretaceous sediments, associated with Tertiary breakup and sea-floor spreading, which hamper the interpretation of seismic data (e.g., Skogseid \& Eldholm, 1989; Brekke et al., 1999; Roberts et al., 1999; Mjelde et al., 2005, 2007; Gernigon et al., 2020; Zastrozhnov et al., 2020).

A total extension in the order of $200 \%(\beta=2)$ has been estimated as the cumulative effect of crustal stretching of the shelf offshore Mid Norway, prior to the continental breakup (Reemst \& Cloething, 2000; Skogseid et al., 2000; Gómez et al., 2004; Torsvik \& Cocks, 2005). Consequently, the crystalline crust is thinned to less than $10 \mathrm{~km}$ under substantial areas beneath the Møre and Vøring basins (e.g., Mjelde et al., 1997, 1998, 2009; Skilbrei et al., 2002; Faleide et al., 2008; Breivik et al., 2011; Osmundsen et al., 2016; Osmundsen \& Péron-Pinvidic, 2018). Raum et al. (2002) inferred crustal thinning to less than $3 \mathrm{~km}$, and it has been suggested that the deepest parts of the Cretaceous Møre Basin may rest on exhumed mantle (Lundin \& Doré, 1997; Osmundsen et al., 2016). 
A narrow continental shelf typifies the Lofoten-Vesterålen margin segment (Fig. 1). The outer shelf, northwest of the Utrøst Ridge, represents the transition to the average 6-7 km-thick, Eocene, oceanic crust (Eldholm et al., 1979; Mjelde et al., 1993). The Lofoten-Vesterålen margin segment contrasts to adjacent margins in terms of crustal structure, breakup magmatism and sediment thickness (Fig. 3) (e.g., Mjelde et al., 1993; Eldholm \& Grue, 1994; Blystad et al., 1995; Tsikalas et al., 2001, 2005; Steltenpohl et al., 2004; Bergh et al., 2007; Færseth, 2012; Hansen et al., 2012). The Lofoten-Vesterålen archipelago, considered as the northwestern margin of the ancient Baltic craton (Olesen et al., 1997), exposes some of the oldest rocks recorded onshore Norway (Griffin et al. 1978). Along the east coast of Andøya (Fig. 1), a c. 750 m-thick succession of Middle-Upper Jurassic and Lower Cretaceous sediments overlie Precambrian basement and outcrop in a localised and fault-bounded basin (Dalland, 1975, 1979, 1981). This location contains the only Mesozoic sediments preserved onshore Norway.

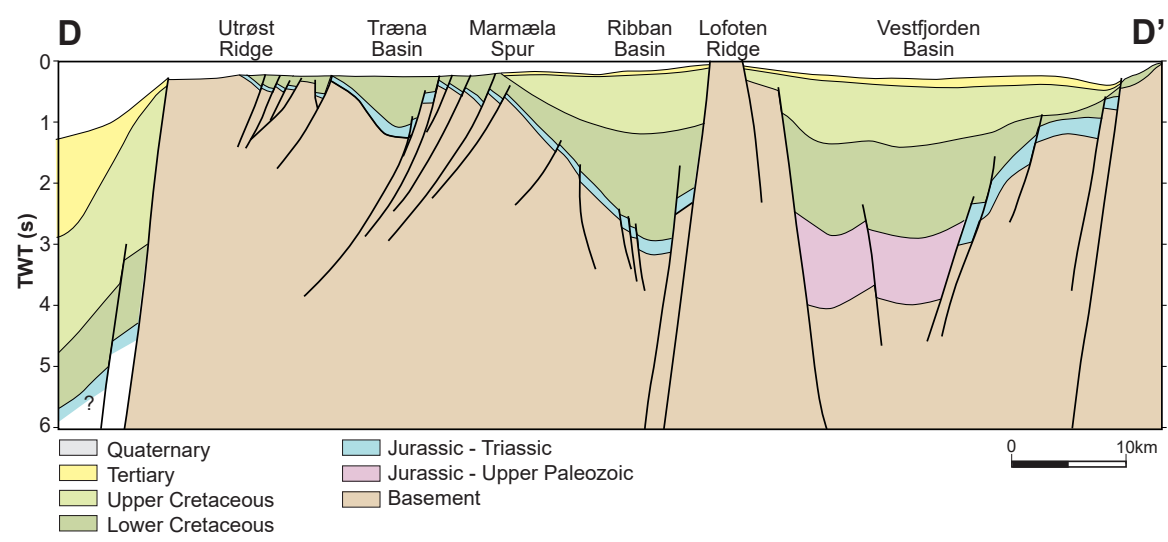

Figure 3. Geoseismic profile showing main structural elements of the Lofoten-Vesterålen area. Location of profile in Fig. 1. Thin Jurassic sediments, which overlie Precambrian basement, are a characteristic feature in most of the shelf area northwest of the archipelago. The expanded, pre-Cretaceous sedimentary succession beneath the Vestfjorden Basin may represent part of a Late Permian-Early Triassic rift basin.

\section{Data and methodology}

This paper is based on knowledge achieved through three decades of work within the Exploration Department and Research Centre at Norsk Hydro, followed by work as consultant for several oil companies. The large number of reports produced by the present author as well as participation in several in house projects, including concession rounds in the Norwegian Sea, gave access to a huge amount of data, including 2D and 3D seismic surveys and most wells drilled offshore Mid Norway. Sedimentological logging of cores from a large number of wells became available, and these data allowed the reconstruction of depositional environments in the eastern part of the Norwegian Sea, of which some results have been published (Gjelberg et al., 1987).

The work performed by the present author involved regional geology, with emphasis on structural development, but also a number of Norwegian Sea licences, where work has addressed the structural geology based on seismic as well as fault seal probability for potential traps, partly based on structural logging of cores performed by the author (Færseth et al., 2007). The author was a member of the committee that defined and described structural elements of the Norwegian Sea (Fig. 1) (Blystad et al., 1995), and a co-author in an earlier publication that described the main structural features in the same region (Gabrielsen et al., 1984).

Striking similarities between the eastern part of the investigated area and the conjugate Greenland margin are evident and, accordingly, East Greenland exhibits good field analogues for sediments 
offshore Mid Norway. The large number of publications from onshore East Greenland became important in compiling this paper, especially regarding Late Palaeozoic and Triassic sedimentation as few wells in the Norwegian Sea have penetrated strata from these particular intervals.

\section{Devonian-Carboniferous structural development and sedimentation}

Devonian tectonic movements led to the development of intramontane basins, preserved in depressions in the coastal area of western Norway (e.g., Steel et al., 1985; Norton, 1986; Andersen \& Jamtveit, 1990; Fossen, 1992; Osmundsen \& Andersen, 2001), and in N-S-trending synforms onshore East Greenland (e.g., Surlyk, 1990; Hartz et al., 2002, 2006; Hamann et al., 2005; Parsons et al., 2017). Within the proximal domain onshore Mid Norway, the crustal thickness is reduced by about $10 \mathrm{~km}$ from a thickness of 38-40 km at the innermost boundary fault system to the east and to the coastal area (Redfield \& Osmundsen, 2013). Extensional structures mapped in the onshore area comprise major shear zones, predominately NNE-SSW trending and dipping to the west. The structures are related to the Devonian orogenic collapse, some with up to tens of kilometres of displacement and almost all reveal top-WNW transport (e.g., Braathen et al., 2000, 2002; Olesen et al., 2002, 2010; Osmundsen et al., 2005). The NE-SW-trending and coast-parallel Møre-Trøndelag Fault Complex (MTFC) (Fig. 1) shows evidence of significant left-lateral strike-slip displacement (e.g., Steel \& Gloppen, 1980; Steel et al., 1985; Bering, 1992; Fossen, 1992; Osmundsen \& Andersen, 2001). In central-northern Norway, the Nesna Shear Zone (Fig. 1) comprises a c. 1 km-thick zone with a penetrative, Early Devonian, top-WSW, ductile fabric (Braathen et al., 2002; Eide et al., 2002; Osmundsen et al., 2003).

Offshore extensions of Devonian extensional structures have been suggested, i.e., Høybakken and Kollstraumen detachments and Nesna Shear Zone (Mosar et al., 2002; Olesen et al., 2002; Osmundsen et al., 2002, 2003: Skilbrei et al., 2002). Breivik et al. (2011), however, stated that seismic data do not confirm the predicted offshore continuation of the detachments onto the shelf beneath the Trøndelag Platform.

\section{Carboniferous development}

The Wandel Sea Basin located onshore and offshore North Greenland together with the Barents Sea region formed a complex, rift-related system during the Carboniferous with the deposition of marine sediments (e.g., Gjelberg \& Steel, 1983; Steel \& Worsley, 1984; Berglund et al., 1986; Gabrielsen et al., 1990; Stemmerik, 1995, 2000; Gudlaugsson et al., 1998). Onshore East Greenland, non-marine Early Carboniferous sediments were deposited in narrow, isolated half-grabens, north of the Scoresbysund (e.g., Surlyk, 1990; Stemmerik, 2000; Hartz et al., 2002, 2006). Regional uplift and erosion involving the East Greenland margin resulted in a major Mid Carboniferous hiatus. Sedimentary basins in the area remained non-marine during renewed Late Carboniferous sedimentation (Surlyk, 1990; Stemmerik, 2000). Carboniferous strata exposed in the western parts of the Traill $\varnothing$ and Geographical Society $\varnothing$ areas have a minimum thickness of 3000 m (Vigran et al., 1999; Parsons et al., 2017).

Onshore central-northern Norway, unroofing and faults associated with the Nesna Shear Zone (Fig. 1) showing effects of Early Carboniferous deformation have been reported (Braathen et al., 2002; Eide et al., 2002). After the top-WSW ductile motion on the Nesna Shear Zone had ceased by Mid Devonian time, the shear system was superceded by steeper Early Carboniferous (335-346 Ma) faults that cut the earlier low-angle ductile shear zones (Eide et al., 2002). 
Several workers have speculated that Carboniferous tectonic events affected the Norwegian Sea region with associated sedimentation (e.g., Ziegler, 1988, 1989, 1990; Blystad et al., 1995; Doré et al., 1997; Roberts et al., 1999; Brekke, 2000; Brekke et al., 2001; Osmundsen et al., 2002, 2003, 2016; Mjelde et al., 2007; Faleide et al., 2008). Brekke et al. (2001, fig. 5) inferred a large central area of a stable unrifted and emergent basement block between Norway and East Greenland, with Carboniferous rift basins on both sides, i.e., onshore East Greenland and as narrow rifts to the east, parallel to the Mid-Norwegian coastline. Later authors (e.g., Nøttvedt \& Worsley, 2006) have adopted this paleogeographic model. Whereas Carboniferous rifting and sedimentation are documented onshore East Greenland, there are no data to support the assumption of Carboniferous rift basins in nearshore areas to the east. Where wells of a shallow drilling project are available along the Lofoten-Vesterålen margin, Upper Palaeozoic sediments are absent, and thin Lower Triassic-Middle Jurassic sediments overlie the Pre-Cambrian basement (Hansen et al., 1992). Commercial wells drilled in the Slørebotn Sub-basin and on the Gossa High confirm a similar development in the SE Møre Basin.

Stemmerik (2000, and references therein) presented paleogeographic maps, spanning the Carboniferous to Late Permian for the northern North Atlantic region. The maps were based on sediments described from onshore East and North Greenland, Svalbard, Bjørnøya and in the western Barents Sea. The paleogeographic maps indicate that Carboniferous sedimentation was limited to the northern part of the region, where Pangea, at this time, was fringed to the north by a huge shelf dissected by deeperwater basins. The area between Norway and East Greenland was interpreted as an emergent land mass, with non-marine Carboniferous sediments restricted to an area onshore East Greenland. Within the area occupied by the present Norwegian Sea, Carboniferous sediments were not deposited south of the Lofoten-Vesterålen archipelago.

In the northern North Sea (Utsira High), the presence of Carboniferous sediments has been suggested by Brekke et al. (2001). Farther north and east of the Viking Graben, Carboniferous sediments are not encountered, neither in well 31/6-1 drilled to basement beneath the Horda Platform nor in wells along the eastern flank of the Sogn Graben (Fig. 1), and Triassic sediments onlap basement at both locations (e.g., Færseth et al., 1995a; Færseth 1996). Hence, in the area offshore West to Mid Norway and NW of the Lofoten-Vesterålen archipelago there is no compelling evidence of major structures and sedimentation resulting from Carboniferous deformation.

\section{Late Permian-Early Triassic rifting, basin develop- ment and sedimentation}

A Mid-Late Permian initiation of a tectonic event is widely recognised in the northern North Atlantic and western Barents Sea, and a marine connection was established between the Barents Sea and the basin onshore East Greenland. Following the non-marine Devonian-Carboniferous sedimentation, this was the first time since the Caledonian Orogeny that marine sediments were deposited onshore East Greenland (Stemmerik, 2000), similar to the basin area offshore Mid Norway.

Workers have suggested Permo-Triassic rifting and sedimentation in most of the investigated area (Dalland, 1981; Larsen, 1987; Ziegler, 1988, 1989, 1990; Schmidt, 1992; Blystad et al., 1995; Swieciki et al., 1998; Ren et al., 1998; Doré et al., 1999; Gabrielsen et al., 1999; Brekke, 2000; Reemst \& Cloetingh, 2000; Brekke et al., 2001; Müller et al., 2005; Nystuen et al., 2006; Bergh et al., 2007; Faleide et al., 2008; Hansen et al., 2012; Osmundsen et al., 2016). However, major Permo-Triassic rift basins are documented only in the eastern part of the study area, where deep basins bounded by faults with throws in the range 6-10 $\mathrm{km}$ at top basement level have been mapped (Fig. 4). 

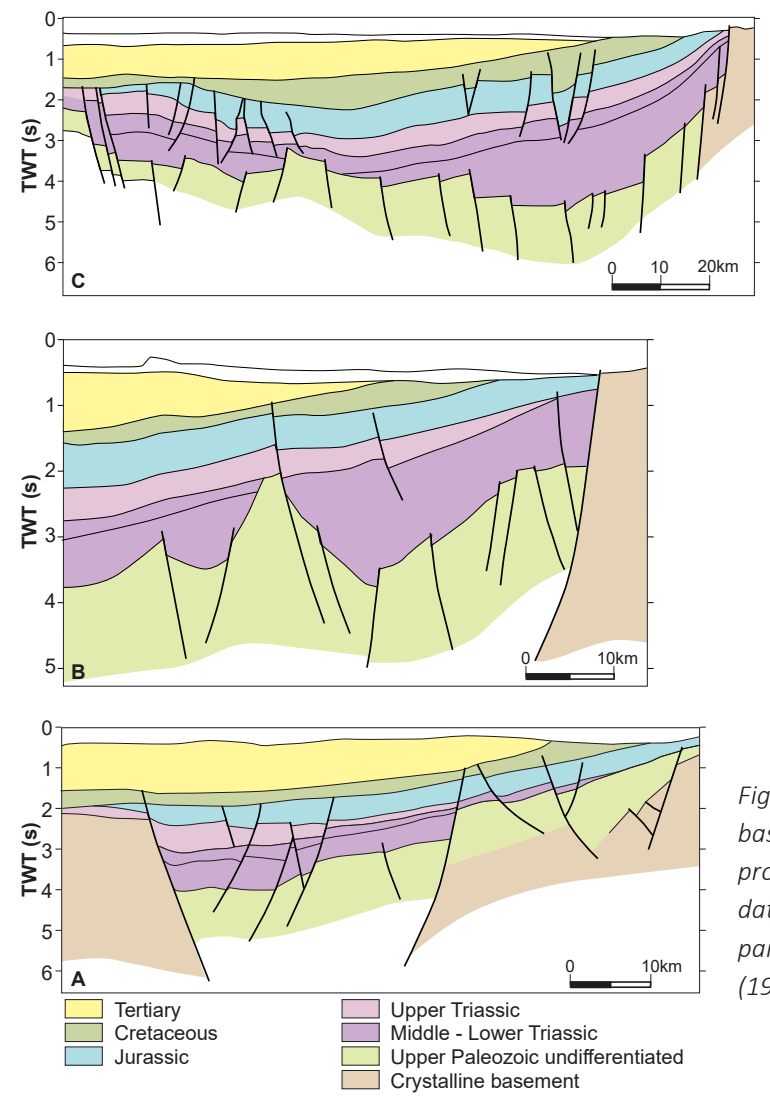

Figure 4. Geoseismic profiles which illustrate deep basins beneath the Trøndelag Platform. Location of profiles in Fig. 1. Based on seismic and scattered well data, Permian sediments may represent a substantial part of the pre-Triassic succession. From Blystad et al. (1995).

The Froan Basin, as defined by Blystad et al. (1995), is essentially a set of half-grabens of alternating polarity along strike. Large normal faults bound the basin, to the southwest against basement of the Frøya High (Fig. 4A) and to the northeast as basin-bounding faults close to the Norwegian mainland (Fig. 4B). Another basin is located farther north, partly beneath the Cretaceous Helgeland Basin (Fig. 1). To the east, pre-Jurassic sediments are juxtaposed against basement across a major fault zone close to the mainland (Fig. 4C). The basin consists of sub-basins separated by a N-S-trending basement ridge, and the depth to magnetic basement is between 8 and $10 \mathrm{~km}$ on both flanks of the basin (Olesen et al., 2002; Breivik et al., 2011). According to Osmundsen \& Péron-Pinvidic (2018), the crustal thickness was reduced to some 20-25 km under the Trøndelag Platform and Halten and Dønna terraces, following the Permo-Triassic extensional episode.

Rift basins beneath the Trøndelag Platform contain infill successions interpreted to result from Late Permian-Early Triassic extension (Blystad et al., 1995; Brekke, 2000; Brekke et al., 2001; Bugge et al., 2002; Osmundsen et al., 2002; Müller et al., 2005). The timing is consistent with rifting described from the coastal area of East Greenland (Surlyk, 1990; Stemmerik et al., 2000; Hartz et al., 2002; Wignal \& Twitchett, 2002; Hamann et al., 2005), western Barents Sea (Berglund et al., 1986; Wood et al., 1989; Gabrielsen et al., 1990; Gudlaugsson et al., 1998) and northern North Sea (Leirvik et al., 1989; Steel \& Ryseth, 1990; Steel, 1993; Færseth, 1996). Faults associated with rift basins pre-date a Late Ladinian-Carnian evaporite interval offshore Mid Norway. Where basins have the shape of half-grabens, sediments thicken down-dip to reach thicknesses up to 2000-3000 m. Müller et al. (2005) subdivided the syn-rift succession into a Late Permian initial rift stage, whereas Lower Triassic sediments were deposited during a rift climax stage (Fig. 5).

Some authors have suggested that Late Permian-Early Triassic faulting beneath the Trøndelag Platform represented a reactivation of Devonian extensional structures (e.g., Braathen et al., 2002; Osmundsen et al., 2002, 2005; Skilbrei \& Olesen, 2005). However, the existence of Devonian extensional features in the offshore area as well as the nature of such reactivation remain controversial (Breivik et al., 2011). 


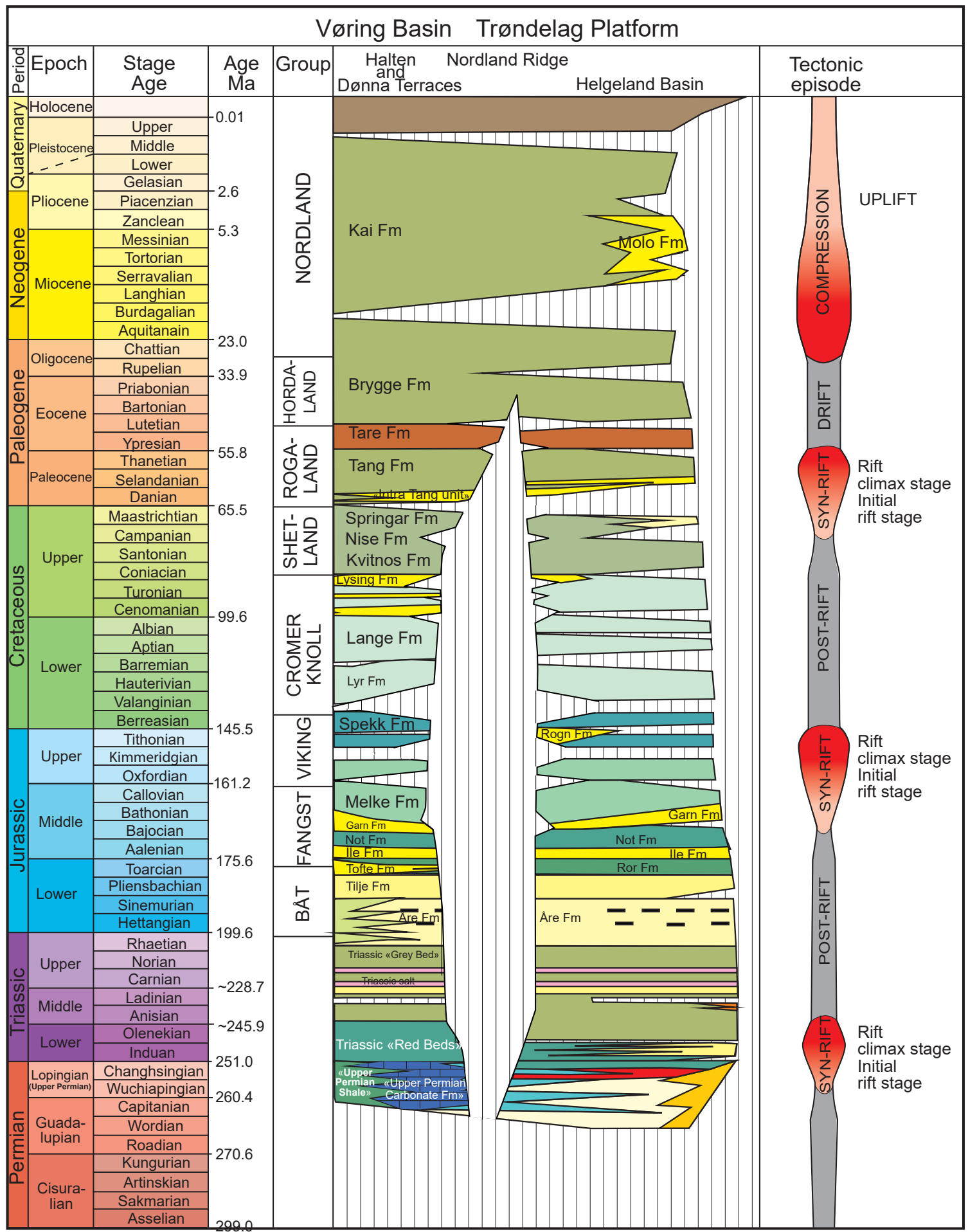

Figure 5. Tectonostratigraphic framework of the Norwegian Sea. The pre-Cretaceous stratigraphy is representative of the eastern basin area, based on some commercial wells and shallow drilling. Yellow colour shows sand-dominated units. See text for lithological description and depositional environments. Post-Caledonian structures result from three significant extensional episodes, separated by long periods of overall tectonic quiescence. There is also a post-Eocene period of compression and uplift.

A minimum 3000 m-thick sediment succession is evident on the southern Halten Terrace, beneath Late Ladinian-Carnian evaporites, and may contain Triassic Red and Grey beds as well as Permian sediments similar to those on the Trøndelag Platform. Beneath the salt, in the hanging wall of a NE-SW-striking fault, an E-SE-dipping seismic reflection offset by normal faults demonstrates tilted fault-blocks and associated syn-rift wedges (Fig. 6). In the immediate hanging wall of the master fault, the syn-rift wedge has a thickness exceeding $1000 \mathrm{~m}$, interpreted to have resulted from the Late Permian-Early Triassic rift episode. 

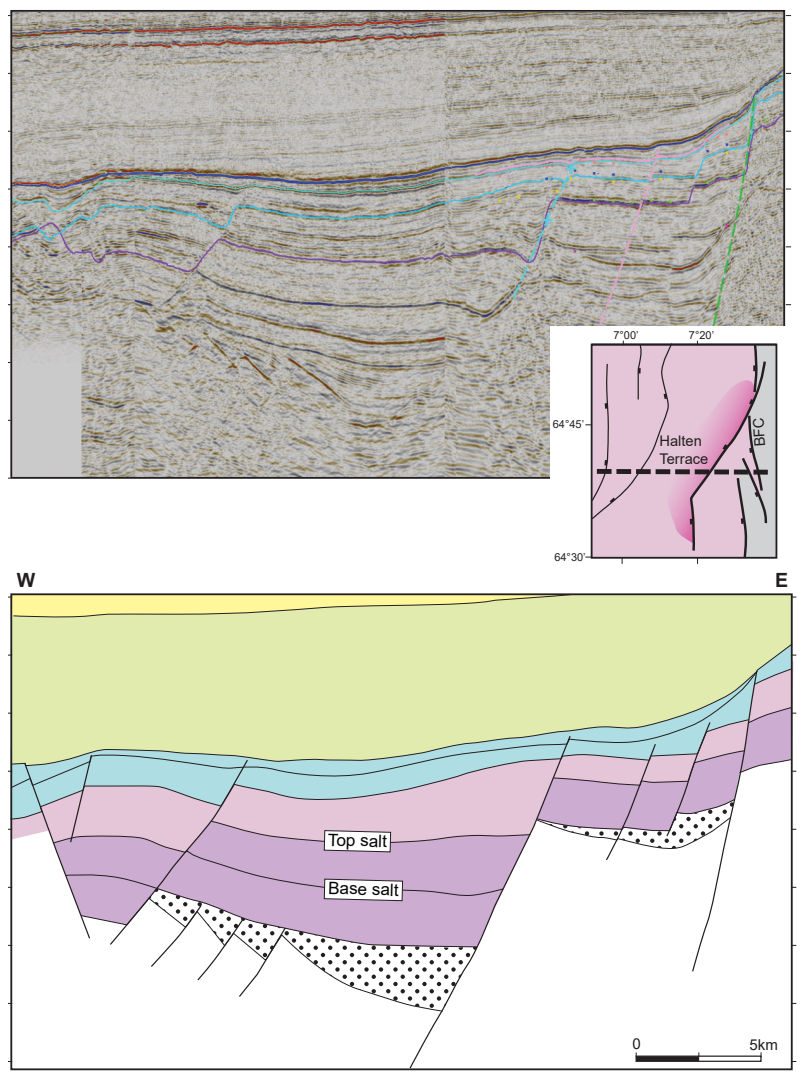

Figure 6. E-W profile in the hanging wall of the Bremstein Fault Complex (BFC), across southern part of blocks 6407/4 and 5 on the Halten Terrace. The syn-rift wedges (stippled), which appear beneath the Late Ladinian-Carnian salt interval, are interpreted to result from the Late PermianEarly Triassic rifting episode. The wedge with maximum thickness is located in the hanging wall of a NE-SW-striking fault at Triassic level (inset). Colours as in Fig. 4.

Beneath the Slørebotn Sub-basin (Fig. 1), Lower-Middle Triassic sediments were penetrated and partly cored in well 6305/12-1 (Fig. 7). NE-SW-striking normal faults in this area have been attributed to Early Triassic extension (Jongepier et al., 1996).

The Sklinna Ridge is a basement high that occupies the westernmost Halten Terrace, bounded to the west by the Jurassic Klakk Fault Complex (Fig. 1). The top of the ridge is $3-10 \mathrm{~km}$ wide, and the ridge extends $140 \mathrm{~km}$ in a $\mathrm{N}-\mathrm{S}$ trend (Blystad et al., 1995). The ridge consists of three separated segments, i.e., two deeply eroded highs and an intervening saddle. The segments to the north and south show flatly eroded basement overlain by Cretaceous sediments. The eastern boundary of the Sklinna Ridge may represent E-dipping basement (Blystad et al., 1995), but along parts of its length it is bounded by E-dipping normal faults where the throw at basement level is up to $4 \mathrm{~km}$. The fault activity was partly pre-Jurassic, and possibly a result of the Late Permian-Early Triassic extension. As argued below, the present Sklinna Ridge is interpreted as the easternmost remnant of a basement land area that existed west of the Halten Terrace, prior to the Jurassic rift climax stage.

\footnotetext{
Figure 7. Geoseismic profile across a major, Jurassic, NE-SWstriking, fault zone of the MøreTrøndlag Fault Complex (Møre margin). Modified from Jongepier et al. (1996). Location of profile in Fig. 1. In well 6305/12-2, Bathonian sandstone overlies basement represented by greenstone. Wells 6305/12-1 and 6205/3-1R are projected from their positions northast of the profile. Latest Volgian and Cretaceous sediments represent passive infill of topography created during the Jurassic extensional episode. Colours as in Fig. 4.
}

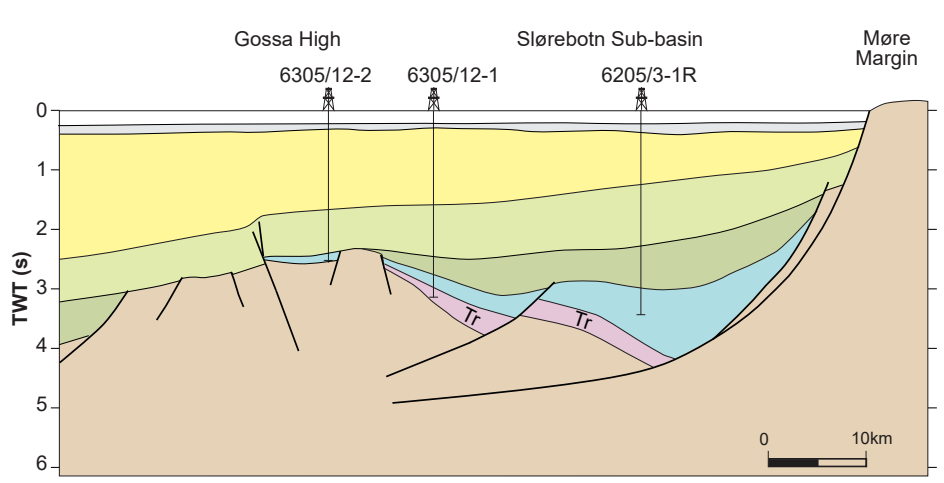


Beneath the deep Cretaceous Vestfjorden Basin (Fig. 1), authors have inferred a post-Devonian to pre-Cretaceous age for a c. 5000 m-thick sequence of sediments above basement (Fig. 3) (Jørgensen \& Navrestad, 1981; Bøen et al., 1984; Blystad et al., 1995; Mjelde et al., 1996). Faults beneath the Vestfjorden Basin project onto land, into the Vestfjorden-Vanna Fault Complex (Forslund, 1988; Gabrielsen et al., 2002), and paleomagnetic studies indicate Permian activity associated with these faults (Olesen et al., 1997). Færseth (2012) interpreted the succession beneath the Vestfjorden Basin as the only indication of a potential, large-scale, Late Permian-Early Triassic rift basin offshore Lofoten-Vesterålen. The author further suggested that this basin, together with the two rift basins beneath the Trøndelag Platform (Fig. 1), might have constituted an en échelon array of major rift basins in the near shore area, due to the NE-SW basement grain where basins are located, which was oblique to the E-W-oriented Late Permian-Early Triassic stretching trend (Færseth et al., 1997; Doré et al., 1999; Mosar et al., 2002; Valle et al., 2002; Torsvik \& Cooks, 2005). A similar en échelon development, controlled by the basement grain has been described onshore East Greenland (Rotevatn et al., 2018).

The Permo-Triassic basin area offshore Mid Norway was flanked to the NW and SE by regional basement highs, governed by the prominent structural grain of the region (Færseth, 2012). The Lofoten-Vesterålen archipelago, the Utrøst Ridge together with the inner shelf along this margin segment (Fig. 1), represent remnants of a regional NE-SW-striking basement high. To the south, the Møre margin and the huge basement block (Gossa High) are remnants of a NE-SW-trending basement high associated with the Møre-Trøndelag Fault Complex (Fig. 1). This was a prominent and long-lived structural element both onshore and offshore Norway (Gabrielsen et al., 1984, 1999; Brekke \& Riis, 1987; Bering, 1992; Graue, 1992; Blystad et al., 1995; Redfield et al., 2005; Osmundsen et al., 2016). Onshore Norway, the width of the fault complex exceeds $50 \mathrm{~km}$ (Olsen et al., 2007). In the offshore area, the NE-SW-trending Slørebotn Sub-basin as well as the Marulk and Magnus basins demonstrate the strong influence of the basement grain. Several ridges and highs also oriented NE-SW, where basement apparently subcrops at Cretaceous level, are all associated with the offshore extension of the Møre-Trøndelag Fault Complex (Fig. 1).

The two basement highs, characterised by eroded and peneplaned top basement prior to the Late Jurassic climax stage, contrast the dramatic basement topography in the basin area offshore Mid Norway (Olesen et al., 2002; Skilbrei et al., 2002; Skilbrei \& Olesen, 2005). During the Late Permian-Early Triassic rift episode, the two basement highs apparently acted as relay ramps, or high relief accommodation zones census Rosendahl (1987). The eastern margin of deep Late Permian-Early Triassic rift basins was shifted progressively to the east across the basement highs; from the $\varnothing$ ygarden Fault Complex along the west coast of Norway (Færseth et al., 1995a; Færseth, 1996), via major faults close to the present coastline of Mid Norway (Fig. 4B, C) and to the Senja Fracture Zone in the southwestern Barents Sea (Fig. 1, top right).

\section{Late Permian syn-rift sedimentation}

Two commercial wells, drilled on the Nordland Ridge (Fig. 1), as early as 1983 and 1997, encountered sediments interpreted to be Late Permian in age. In well 6609/7-1, drilled up-flank on the ridge, $35 \mathrm{~m}$ of dolomite and dolomitic limestone rest directly on Precambrian metasandstone (Slagstad et al., 2011). In well 6608/8-1, a 250 m-thick succession of carbonates and shales was penetrated. Well 6307/1-1S, drilled in 2018, encountered carbonate rocks in the transition zone between the Frøya High and the Froan Basin. The carbonates of assumed Late Permian age overlie metasedimentary rocks of currently unknown age.

In addition to commercial wells, shallow stratigraphic drilling has proven $370 \mathrm{~m}$ of Upper Permian sediments, to demonstrate deep basins located close to the present Mid-Norwegian coastline (Bugge et al., 2002). In well 6611/9-U1, at the northeastern margin of the Late Permian-Early Triassic basin area, the lower $170 \mathrm{~m}$ of the succession consists of reddish, well-sorted sandstone of shallow-marine origin, 
followed by a 20 m-thick anhydrite unit, indicative of an arid climate. This unit is overlain by $80 \mathrm{~m}$ of a lower turbidite sand-shale succession. The uppermost $100 \mathrm{~m}$ of the drilled Upper Permian succession is characterised by mudstone interbedded with thin siltstones, representing distal thin-bedded turbidites and hemipelagic deposits, reflecting periods of anoxia.

Müller et al. (2005) correlated Upper Permian sediments encountered offshore Mid Norway with the Foldvik Creek Group on East Greenland. The group consists of four formations; the Huldal, Karstryggen, Ravnefjell and Wegener Halvø formations (e.g., Surlyk et al., 1986; Surlyk, 1990; Christensen et al., 1993; Stemmerik et al., 1993, 2001; Hartz et al., 2006). Poorly sorted, immature, fluvial conglomerate and sandstone of the Huldal Formation are time equivalent with the shallow-marine sandstone succession in well 6611/9-U1. The Karstryggen Formation consists mainly of limestone with interbedded gypsum (hypersaline conditions), corresponding to the 20 m-thick anhydrite unit (Bugge et al., 2002; Müller et al., 2005). The Ravnefjeld Formation, similar to the lower turbidite and shale succession in the shallow well, consists of black bituminous mudstones (e.g., Surlyk et al. 1986, Christensen et al., 1993). The uppermost part of the Permian turbidite succession may represent an equivalent to the Schubert Dal Formation on East Greenland, interpreted as a submarine fan system (e.g. Stemmerik et al., 2001).

The Ravnefjeld Formation is interfingering and laterally equivalent to the Wegener Halvø Formation, which comprises carbonates deposited on structural highs or along basin margins. Carbonates may infill karstic surfaces (Stemmerik et al., 1993), and bioherms and reef buildups occur in places in the formation. The carbonates encountered in wells drilled on the Nordland Ridge and in well 6307/1-1S at the margin of the Frøya High may correspond to the Wegener Halvø Formation, deposited on structural highs along a western basin margin.

Based on seismic, Upper Permian sediments may compose a substantial part of the pre-Triassic succession beneath the Trøndelag Platform (Fig. 4). Scattered well data indicate that shallowmarine sandstone and deltaic systems, sourced from the Baltic Shield, dominated along the basin margin to the east, whereas carbonates were deposited above basement highs to the northwest and southwest. In most of the basin area however, Upper Permian deposits are interpreted as fine-grained, shallow-marine sediments (Fig. 5) (Müller et al., 2005). During the latest Permian, a relative sea-level rise took place and changed the depositional environment to deep-water conditions.

\section{Early Triassic syn-rift sedimentation}

Few commercial wells have encountered Lower Triassic sediments, and mainly on the Nordland Ridge (e.g., 6507/6-1). Lower Triassic sediments (c. $400 \mathrm{~m}$ ) were sampled in shallow wells 6611/9-U1, U2 at the eastern margin of the Permo-Triassic basin area (Bugge et al., 2002). The boundary between Permian and Lower Triassic sediments is probably conformable in the shallow wells, with an interval of amalgamated turbidites at the boundary. The wells demonstrate that along the eastern part of the basin, the lowermost Triassic is typically shale and mudstone with thin siltstone and sandstone beds, reflecting deposition on the basin floor or at the base-of-slope, dominated by turbidites. In most of the basin area, the lowermost Triassic is interpreted to be dominantly shales and mudstones (Müller et al., 2005). However, the lateral distribution of Lower Triassic syn-rift sediments is assumed to be complex due to the asymmetry of rift basins with variation from deep to shallow-marine environments over short distances.

Thick Upper-Middle Triassic successions, dominated by Red and Grey beds, have been drilled on the NE flank of the Frøya High, in wells 6407/10-3 and 4. The wells with TD at $2973 \mathrm{~m}$ and $3224 \mathrm{~m}$ were drilled to basement represented by fractured granite, which yielded an age of $437 \mathrm{Ma}$ (Slagstad et al., 2011), and metamorphic sandstone, respectively. The two wells demonstrate that Lower Triassic syn-rift sediments are absent at these locations. 
Beneath the Slørebotn Sub-basin, Triassic sediments that attain a stratigraphic thickness of minimum $600 \mathrm{~m}$ were encountered in well 6305/12-1 (Fig. 7), and the succession was assigned an Early-Middle Triassic age (Jongepier et al., 1996). The Triassic rocks consist of conglomerates, sandstones and mudstones, with a fining-upwards character, and sediments were deposited in an arid alluvial environment. The thick section of stacked conglomerates at the base contains cobble-size clasts, which indicate close proximity to a western source area. In well 6305/12-2 drilled on top of the Gossa High (Fig. 7), Bathonian sediments rest directly on basement represented by greenstone. The absence of Triassic rocks indicates that this area has been exposed and eroded, and is interpreted as part of the source area for coarse-grained Lower Triassic sediments encountered a short distance to the east.

The oldest sediments proven along the Lofoten-Vesterålen margin occur in a 175 m-thick Early Triassic succession overlying Precambrian basement and deposited in a localised basin northwest of the Lofoten Ridge. In shallow well 6710/03-U-03, the cored succession is interpreted as erosional products from the exposed basement (Hansen et al., 1992). The succession is sand dominated, fining upwards, and represents immature alluvial-fan deposits (Hansen et al., 2012). Farther northeast, in the shelf area off Vesterålen and in the outcrop onshore Andøya (Fig. 1), Middle Jurassic sediments overlie basement, and in both areas thin conglomerates at the base were derived from the underlying basement (Dalland, 1975, 1979; Hansen et al., 1992). The eroded and smooth top basement surface shows evidence of deep weathering (Sturt et al., 1979; Mørk et al., 2003). Hence, basement rocks were peneplaned and subaerially exposed for a long period before the area was flooded and sedimentation initiated in the Middle Jurassic. In East Greenland, the Wordie Creek and Pingo Dal formations represent the Early Triassic sedimentation, consisting of submarine-fan and alluvial-fan/axial flood-plain deposits, respectively. The formations signify deposition in a syn-rift setting with high sedimentation rates (Oftedal et al., 2005).

\section{Permo-Triassic rift basins between Norway and Greenland}

Within the Norwegian Sea, regional-scale Late Permian-Early Triassic rift basins have been mapped beneath the Trøndelag Platform (Fig. 4). There are indications of rifting of this generation also beneath the Vestfjorden Basin (Fig. 3), and the Halten Terrace (Fig. 6), whereas effects of Early Triassic fault activity are inferred beneath the Slørebotn Sub-basin (Jongepier et al., 1996). Onshore East Greenland, Late Permian-Early Triassic extension resulted in basins bounded by major E to ESE-dipping faults (e.g., Surlyk, 1990; Hartz et al., 2002, 2006; Lundin \& Doré, 2002; Hamann et al., 2005; Parsons et al., 2017).

Whether Late Permian-Early Triassic extension affected areas now buried beneath the Cretaceous Vøring and Møre basins cannot be categorically stated. However, interpretations at depth indicate relatively thin intervals between assumed top crystalline basement and the base Cretaceous over most of the area (Blystad et al., 1995; Skogseid et al., 2000; Raum et al., 2002; Skilbrei et al., 2002; Gómez et al., 2004; Breivik et al., 2011; Osmundsen et al., 2016; Zastrozhnov et al., 2020). Long-offset seismic-reflection data reveal that uncertainty remains regarding pre-Cretaceous lithologies, envisaged by the contrasting interpretations (e.g., Nirrengarten et al., 2014; Osmundsen et al., 2016; Osmundsen \& Péron-Pinvidic, 2018; Zastrozhnov et al., 2020). Accordingly, whether rocks at depth are composed of dense sediments, continental crystalline crust or altered mantle remain poorly constrained.

Mosar et al. (2002) presented an evolutionary rift model for the Greenland-Norway separation with the locus of Late Permian-Early Triassic rifting at the eastern margin, i.e., beneath the Trøndelag Platform. Also, in the northern North Sea, beneath the Horda Platform, a Late Permian-Early Triassic rift basin characterised by faults with throws up to $4-5 \mathrm{~km}$ at top basement level occupy the eastern part of the 200 km-wide North Sea basin (Steel \& Ryseth, 1990; Færseth et al., 1995a; Færseth, 1996). Hence, although comparable Permo-Triassic sediments were deposited offshore Mid Norway and along the 
conjugate Greenland margin (e.g., Müller et al., 2005), these two depositional areas did not represent the margins of an intra-continental, 200-400 km-wide, Late Permian-Early Triassic rift basin, a paleogeographic model published by several authors (Dalland, 1981; Gage \& Doré, 1986; Larsen, 1987; Ziegler, 1988, 1989, 1990; Swiecicki et al., 1998; Brekke et al., 2001; Seidler et al., 2004; Müller et al., 2005; Nystuen et al., 2006).

\section{Middle Triassic-early Middle Jurassic post-rift development}

Middle Triassic-early Middle Jurassic time is regarded as a period of overall tectonic quiescence, and the c. 70 million-year interval separated two major rifting episodes (Fig. 5). Sediments that accumulated in the basin area beneath the Trøndelag Platform and the Halten and Dønna terraces achieved a total thickness of 2500-3000 m, whereas time-equivalent sediments are largely absent above basement highs surrounding the basin (Færseth, 2012).

During this period, extensional tectonics have been suggested, but interpretations are generally subdued and based on local observations (e.g., Blystad et al., 1995; Fjellanger et al., 2005; Nøttvedt et al., 2008; Marsh et al., 2010; Ravnås et al., 2014; Ichaso et al., 2016; Osmundsen et al., 2016). Accordingly, there is no consistent timing and understanding of the regional implications of postulated tectonic events and compared with the three major rift episodes (Fig. 5) they appear as local and minor disturbances.

Although the post-rift sedimentation took place during a tectonically quiet period, highly variable depositional conditions have been registered. Apart from external factors, such as variable climatic conditions and global sea-level changes, with periodical flooding of the basin, local factors influenced the basin physiography and depositional conditions. Middle Triassic sediments were deposited above a substrate characterised by a rough topography due to the preceding rift episode. Sediment loading and the continuous differential compaction of the deposited sediments, created accommodation space for additional sediments. Halokinetic movements of thick latest Middle-Upper Triassic salt caused significant thickness variations of overlying sediments, especially on the Halten Terrace (Jackson \& Hastings, 1984; Withjack et al., 1989; Pascoe et al., 1999; Corfield \& Sharp, 2000; Corfield et al., 2001; Færseth \& Lien, 2002; Richardson et al., 2005; Marsh et al., 2010; Wilson et al., 2013, 2015).

The boundary between Lower and Middle Triassic successions represents a change from marine sediments to coastal plain, flood-plain and lacustrine deposits. Middle Triassic (Anisian-Ladinian) sediments exceed $1000 \mathrm{~m}$ in thickness in most of the basin. After deposition of this succession, the topography created by Late Permian-Early Triassic rifting was levelled and younger sediments were deposited over a wide and relatively flat area.

The few wells which have drilled Middle Triassic sediments, contain red mudstones interbedded with thin, commonly heterolithic, sandstone units. Well 6407/10-3, located on the northeastern flank of the Frøya High, penetrated $1131 \mathrm{~m}$ of Triassic sediments, where Middle Triassic Red Beds some 200-250 in thickness, overlie fractured granitic basement. Beneath the Slørebotn Sub-basin, the Triassic sedimentary succession in well 6305/12-1 is fining upwards, and siltstones and mudstones, which dominate in the upper part of the interval, are regarded as Middle Triassic Red Beds (Jongepier et al., 1996).

Offshore Mid Norway, a change in depositional environment at the end of Middle Triassic is evident, and evaporites then became an important element of the stratigraphy. Significant climatic changes took place during the Triassic, reflecting the northward movement of the Laurentian and Baltic plates. 
This implied that the area under consideration moved from a semi-arid climatic zone into a temperate zone close to the Triassic-Jurassic transition, with the study area located between $40^{\circ}$ and $50^{\circ} \mathrm{N}$ in the Latest Triassic (Torsvik et al., 2003; Torsvik \& Cocks, 2005). Late Ladinian-Carnian salt, deposited in a restricted basin, reflects the arid climatic conditions. The evaporite succession, penetrated by well 6507/12-2 on the Trøndelag Platform, has a total thickness close to $900 \mathrm{~m}$ and consists of two salt intervals separated by a mud unit (Jacobsen \& van Veen, 1984). On the NE Halten Terrace, two salt units with a total thickness of $800 \mathrm{~m}$, separated by some $500 \mathrm{~m}$ of claystone/shale, were drilled in well 6507/12-2. Based on seismic (Fig. 6), salt is present and comparable in thickness with that on the Trøndelag Platform, over most of the terrace area, but becomes thinner to the north onto the Dønna Terrace (well 6507/6-1).

The Kolledalen, Solfaldsdal and the Kap Seaforth members of the Gipsdalen Formation represent the Middle Triassic succession onshore East Greenland. The formation contains eolian, fluvial and lacustrine sediments (Clemmensen, 1980). Thick salt is not present, although sediments of the Kap Seaforth Member may reflect more or less the same climatic conditions. This member, Late Landinian in age, is characterised by gypsum-bearing sandstone and mudstone, deposited in a continental sabkha environment with interbedded eolian dunes (Clemmensen, 1978).

The uppermost Triassic (Norian-Rhaetian), 600 to $800 \mathrm{~m}$ in thickness, is penetrated in wells drilled on the Trøndelag Platform and the Halten and Dønna terraces. The Norian succession consists mainly of red sandstone and shale. The sand ratio increases to the south and east and reflects a rhythmic alternation between fluvial channel and overbank deposits with fine-grained flood-plain and lacustrine deposits.

During the Norian, a change in the depositional system took place and Grey Beds, mainly of flood-plain and coastal plain origin, replaced the Red Beds, reflecting the onset of a significant climatic change. In well 6407/10-3 drilled on the Frøya High, Grey Beds are conglomeratic in a core representing the uppermost $23 \mathrm{~m}$ of the thick Triassic succession drilled in this well. The conglomerate probably represents braided stream deposits, deposited close to a western source area. The coarseningupward trend within the Upper Triassic succession corresponds to a similar trend seen in East Greenland (Clemmensen, 1978).

\section{Basement high in the Norwegian Sea as source for coarse-grained sediments}

In publications from an early stage of exploration (e.g., Dalland, 1981; Gage \& Doré, 1986; Larsen, 1987; Ziegler, 1988, 1989, 1990), but also in more recent contributions (e.g., Johannesen \& Nøttvedt, 2006; Ravnås et al., 2014), authors have presented Jurassic paleogeographic maps which exhibit a c. 200 kmwide zone of intra-continental rifting. East Greenland and the shelf offshore Mid Norway formed the two opposing margins of the wide rift basin, and sediments were assumed to have been sourced from East Greenland and the Fennoscandia hinterlands, respectively.

As described below, abundant well data prove that the coarsest grained and most fluvially influenced Lower and early Middle Jurassic sediments were deposited along the western part of the Halten Terrace. Hence, based on sedimentological evidence, including heavy-mineral studies (Morton \& Chenery, 2009; Morton et al., 2009), a land area existed west of the Halten Terrace. The large amount of coarse clastics, i.e., pebbly sandstone and conglomerate, entering into the basin from the west, suggests a considerable size for the land area.

Several workers have recognised coarse-grained sediments on the Halten Terrace, for which they have invoked a westerly source. However, the origin, position and areal extent of suggested land areas are 
poorly constrained. A local source area, represented by an elongate island or a belt of islands, has been suggested (e.g., Doré 1992; Quin et al., 2010), whereas Ravnås et al. (2014) regarded the Sklinna Ridge as the source for the coarse clastics. However, land areas with limited areal extent would have had small water catchments, unlikely to form large river deltas. Authors have also invoked larger source areas, by some termed the 'Grip High' (e.g., Ehrenberg et al., 1993; Johannesen \& Nøttvedt, 2006; Messina et al., 2014).

Brekke et al. (2001) suggested a land mass from the Aalenian to Late Bathonian in the area now occupied by the Møre and Vøring basins, with the present deep Cretaceous basins as areas of uplift, subaerial exposure and erosion. This would imply that Lower and Middle Jurassic sediments are missing beneath the Cretaceous basins, an assumption at odds with depositional models presented by a number of authors.

A huge land area exposed for erosion and bounding the Halten Terrace to the west is the configuration favoured in this study as it explains the dominance of coarse-clastic deposits on the terrace. Brekke et al. (2001) attributed Aalenian-Late Bathonian uplift to thermal domes, a model also favoured by Doré (1992), Brekke et al. (1999) and Brekke (2000). However, the Caledonian Orogeny, which climaxed with the Early Devonian collision and the subduction of the Baltic craton underneath Laurentia, resulted in a mountain range several kilometres high (e.g., Andersen \& Jamtveit, 1990). The metamorphosed rocks of the orogen onshore Norway and East Greenland remained important sources for sediments until the Cretaceous period.

As an alternative model, it is suggested that the land mass that represented the source for proven coarse-clastic Mesozoic sediments comprised remnants of the Caledonide orogen. This basement high might have occupied the area between the Halten Terrace and Liverpool Land, at the east coast of Greenland. As a corollary, Jurassic as well as Permo-Triassic sedimentation in the Norwegian Sea was restricted to a basin area bounded to the west by metamorphosed rocks of the Caledonian mountain range, a notion also supported by wells drilled in the SE Møre Basin, i.e., 6305/12-1, 6305/12-2 and $6306 / 10-1$

Bathonian coarse clastics encountered in the three wells were deposited in fluvial environments, with an exposed basement high to the northwest as the source area. The Bathonian Garn Formation unconformably overlies basement in wells 6306/10-1 and 6305/12-2, and Middle Triassic sediments in well 6305/12-1 (Fig. 7).

Well 6306/10-1 reached TD in a medium-grained diorite, which yielded an age of $447 \mathrm{Ma}$ (Slagstad et al., 2011). According to these authors, the age and isotopic compositions overlap with major magmatic complexes in the Caledonian Upper and Uppermost Allochthons in the coastal area onshore Mid Norway. In well 6305/12-2, drilled on the crestal part of the Gossa High (Fig. 7), Bathonian sediments overlie basement represeted by greenstone. Early Palaeozoic greenstones are typical rocks of the West Norwegian Caledonides, preserved in structural depressions along the southwestern coast of Norway (e.g., Færseth et al., 1977; Færseth, 1982; Brekke \& Solberg, 1987).

The coarse-grained Bathonian sediments encountered in well 6305/12-2 were deposited in an alluvial fan/flood-plain environment dominated by gravity flow processes (Jongepier et al., 1996). The sediments are of a more proximal character than in well 6305/12-1 drilled $10 \mathrm{~km}$ to the east. The lateral change indicates that Middle Jurassic sediments beneath the Slørebotn Sub-basin were sourced from a basement area represented by the present Gossa High, but possibly also including a northwest extension of this high. This assumption is supported by seismic profiles across the Møre Basin (e.g., Osmundsen et al., 2016), which indicate that the Gossa and Vigra highs (Fig. 1) might have formed a continuous basement high prior to the Kimmeridgian-mid Volgian rift climax stage. 
As described above, Lower Triassic syn-rift sediments, drilled and partly cored in well 6305/12-1, have a thick section of stacked conglomerate at the base, which indicates proximity to a source area. The conglomerate contains cobble-size clasts of greenstone, i.e., similar to the substrate encountered beneath Bathonian sediments on the present crest of the Gossa High (Fig. 7). The coarse clastics were deposited in an alluvial environment, with an exposed basement high to the west as the catchment area. Based on these observations, the Gossa and Vigra highs are interpreted as a potentially continuous Triassic, as well as Jurassic, uplifted basement area, and most likely connected to the land mass that existed west of the Halten Terrace.

\section{Early-Middle Jurassic post-rift sedimentation}

Lower and early Middle Jurassic sediments in the eastern part of the study area show evidence of periods with deposition of shallow-marine, tidal-influenced sands. The strong tidal influence is regarded to reflect periods when the Mid-Norwegian shelf was traversed by shallow epicontinental seaways that connected the Tethys Ocean in the south to the high paleo-latitude Boreal Sea (e.g., Brekke et al., 2001; Allison \& Wells, 2006; Messina et al., 2014; Korte et al., 2015). Assuming a basement high between the Halten Terrace and the basin onshore East Greenland, the seaway was situated to the east of, rather than along, a wide Jurassic rift-basin between East Greenland and the Norwegian mainland. Observations from the Jameson Land Basin on East Greenland, suggest a narrow branch of the Jurassic seaway to the west (Doré, 1992; Brekke et al., 2001; Surlyk, 2003; Quin et al., 2010). Within this basin, located west of the Liverpool Land peninsula, deposition of Early to Middle Jurassic, tide-dominated sand intervals have been described (e.g., Surlyk, 1991; Dam \& Surlyk, 1992; Koppelhus \& Dam, 2003; Surlyk, 2003). Surlyk (1990) presented evidence from Jameson Land of sediment influx from a land area located east of this narrow seaway.

The Jurassic post-rift succession is extensively drilled and cored east of the Møre and Vøring basins, where sediments of this generation achieved a total thickness approaching $1000 \mathrm{~m}$. Sand-prone units of the Båt and Fangst groups (Fig. 5) were associated with major transgressions, which might be diachronous, becoming younger towards the western and eastern margins of the basin with indications of erosion (Gjelberg et al., 1987). Lower Jurassic, tide-dominated, sheet-sand complexes, i.e., the Tilje and lle formations, represent the most important reservoirs on the Halten and Dønna terraces (e.g., Blystad \& Søndenå, 2005; Østvedt et al., 2005).

The boundary between Upper Triassic sediments and the overlying, Early Jurassic Åre Formation is gradual, characterised by the occurrence of coal, thicker channel sandstone units and an increasing number of greyish-coloured mudstone beds (e.g., Gjelberg et al., 1987; Svela, 2001). A large number of wells drilled offshore Mid Norway have penetrated the 300-500 m-thick, latest Rhaetian-Sinemurian Åre Formation, or have TD within the formation. This is because fluvial sandstones of the formation are considered to be the lowermost potential reservoir units in the investigated area. The coal-bearing Åre Formation was deposited in extensive flood plains (Gjelberg et al., 1987; Dalland et al., 1988; Kjærefjord, 1999; Svela, 2001), and the coal development is consistent with the well-established interpretation of a humid climate throughout the Early Jurassic. The thickest coal beds, situated in the lower part of the Åre Formation, have a good source potential for gas (Helgesen et al., 2000; Martinius et al., 2005; Messina et al., 2014).

North of Lofoten, a 150 m-thick Rhaetian-Pliensbachian succession of claystone and siltstone interbedded with coal and channel sandstone, cored by a shallow drilling programme (well 6710/03U-01), is interpreted as the Åre Formation (Hansen et al., 1992). In East Greenland, the Kap Steward Group, exposed on Jameson Land, reaches thicknesses of more than 600 m (Surlyk, 2003), and represents an equivalent to the Åre Formation. 
At the end of the Sinemurian, a change in depositional environment is marked by a sudden transition from the relatively fine-grained upper part of the Åre Formation to a sandier unit with much thicker sandstone beds, representing the lower part of the Pliensbachian Tilje Formation (Dalland et al., 1988). The Tilje Formation consists of heterolithic deposits, representing a wide range of depositional environments from fluvial channels to offshore facies. Several publications have described the development of the Tilje Formation as well as reservoir properties, which remain relatively good at burials deeper than 4500 m (e.g., Gjelberg et al., 1987; Ehrenberg, 1993; Dreyer, 1992; Brekke et al., 1999; Martinius et al., 2001, 2005; Storvoll et al., 2002; Blystad \& Søndenå, 2005; Klefstad et al., 2005; $\emptyset$ stvedt et al., 2005; Ravnås et al., 2014; Ichaso et al., 2016). The Fennoscandian hinterland to the east was a sediment source area, although deltaic facies with mouth-bar complexes and the large amount of relatively coarse-grained sediments entering into the basin from the west (e.g., Gjelberg et al., 1987) are also evidence of the land area to the west. The Tilje Formation has thicknesses varying from less than $100 \mathrm{~m}$ to close to $300 \mathrm{~m}$, as in well $6406 / 2-1$ on the western Halten Terrace. The thickness variations, especially on the Halten Terrace, are partly due to halokinetic movements of the underlying salt.

In East Greenland, the marine transgression at the end of the Sinemurian marks the boundary between the lacustrine environment of the underlying Kap Stewart Group and a marine environment represented by the Neill Klinter Group (Surlyk, 1990; Dam \& Surlyk, 1992). The lower part of the Neill Klinter Group is time equivalent to the Tilje Formation, and the group is well exposed on Jameson Land (Surlyk, 2003).

A major transgression took place at the end of the Pliensbachian, and most of the basin offshore Mid Norway was rapidly flooded (e.g., Ravnås et al., 2014). The Toarcian sediments immediately above the transgressive surface are mainly bioturbated mudstone and shale, but with a more silty and sandy development towards the western margin of the basin. Dalland et al. (1988) defined the predominantly fine-grained succession as the Ror Formation, whereas sandstones within the formation were defined as the Tofte Formation, which are usually located in the lower and middle parts of the succession (Fig. 5). The Ror Formation varies in thicness from a few metres to more than $160 \mathrm{~m}$, whereas the Tofte Formation is more than 200 m thick on the western Halten Terrace, as in well 6406/2-7, where it appears very blocky (Ravnås et al., 2014).

The Tofte Formation is present as thin sandstones in the central part of the basin, whereas coarse-grained sediments were deposited on the western Halten Terrace (Gjelberg et al., 1987; Dalland et al., 1988; Johannesen \& Nøttvedt, 2006; Ravnås et al., 2014), locally consisting of pebbly sandstone and granules, e.g., well 6506/12-1. In this well, large foresets represent deltaic/shoreline clinoforms (Gjelberg et al., 1987). Clinoforms are also described in the time-equivalent Harris Fjeld Member of the Ostreaelv Formation on East Greenland (Surlyk, 2003).

The late Toarcian to Aalenian lle Formation represents tidally influenced shallow-water conditions, and the rapid progradation of coarse clastic sediments led to a gradual infilling of the basin. The depositional environment of the lle Formation was very similar to that of the Tilje Formation (Gjelberg et al., 1987, Johannesen \& Nøttvedt, 2006). Although areally extensive, the thickness of the formation is generally less than $80 \mathrm{~m}$. The lower part of the formation reflects deposition in a lower to upper shoreface, but may also show tidal-channel and sub-tidal bar complexes. Thick, massive or slightly coarsening-upwards sandstone units are common, particularly in the western and central Halten Terrace, e.g., the upper part of the formation in well 6506/12-1, probably representing delta-front and mouth-bar complexes, sourced from the land area to the west (e.g., Ravnås et al., 2014). The uppermost part of the lle Formation is fining up in some wells on the Halten Terrace, e.g. wells 6506/12-3, 6407/1-2 and 3, with a heterolithic development and strong wave influence, representing bay and inner-shelf deposits. The top of the lle Formation is expressed as a marked transgressive surface, which can be correlated all over the Halten/Dønna terraces and the Trøndelag Platform, and defines the transition to the overlying Not Formation. 
The Trefjord Bjerg Member in East Greenland represents a time equivalent to the lle Formation, and consists of widely distributed shoreface sand and tidal-channel deposits (Koppelhus \& Dam, 2003; Koppelhus \& Hansen, 2003; Surlyk, 2003).

The Aalenian-Early Bajocian Not Formation consists mainly of shale and mudstone with thin siltstone stringers in the central part of the basin. In the type well (6507/11-3) and the reference well (6407/ 1-3), both drilled on the Halten Terrace, the thickness of the formation is $14.5 \mathrm{~m}$ and $37 \mathrm{~m}$, respectively (Dalland et al., 1988). The Not Formation reflects a sudden transition to brackish water (very low salinity) offshore conditions. The regional distribution of this low-salinity facies, present in East Greenland, on the Mid-Norwegian shelf and possibly in the northern North Sea (Rannoch Formation), suggests a large basin area dominated by freshwater or brackish water conditions with reduced circulation. This development might be related to a period with barriers towards the Boreal Ocean to the north and/or to the Tethys Sea in the south. The salinity increases gradually upwards in the Not Formation, to become open marine in the upper part, which indicates a change in the basin configuration.

The Not Formation corresponds to the Aalenian-Early Bajocian Sortehat Formation in East Greenland (Koppelhus \& Hansen, 2003; Surlyk, 2003). The formation has a pronounced maximum flooding surface at the base, similar to the Not Formation, and consists mainly of black offshore mudstones, subordinate siltstones and very fine-grained sandstones. Similar to the Not Formation, the lower part of the Sortehat Formation represents very low salinity, but also in this formation, the salinity increases upwards to fully open marine conditions in the upper part.

The Early Bajocian started with an overall relative sea-level fall and a continuous sand body, i.e., the lower part of the Garn Formation, developed within the basin offshore Mid Norway. The top of the Garn Formation is strongly diachronous, with a gradually younger and more coarse-grained development to the west and east compared with deposition in the axial part of the basin. As argued below, the Jurassic rift episode was initiated in the Bajocian, i.e., during deposition of the Garn Formation. As a corollary, the lower part of the Garn Formation represents the final stage of the c. 70 million-year long period characterised by tectonic quiescence, whereas the upper part represents syn-rift sediments deposited during an initial stage of the Jurassic rifting episode (Fig. 5).

An overall relative sea-level rise started in the Mid Bajocian and continued throughout the Bathonian. The Garn Formation comprises a complex depositional system (Gjelberg et al., 1987, Dalland et al., 1988; Johannesen \& Nøttvedt, 2006; Messina et al., 2014; Ravnås et al., 2014). During the transgression, several progradational units were stacked on top of each other, commonly with upper shoreface/ mouth-bar sediments amalgamated, and little or no fine-grained sediments are preserved between each cycle system. The Garn Formation, representing a potential reservoir, is widely distributed in the eastern part of the study area, although the thickness varies considerably. The thickness is usually less than $100 \mathrm{~m}$, but thicknesses of $110 \mathrm{~m}$ in the Tyrihans Field (block 6407/1) and $120 \mathrm{~m}$ in well 6506/11-3 are recorded in the western Halten Terrace.

Messina et al. (2014) performed a comprehensive study of the Garn Formation based on geophysical data and sedimentological logging of c. $700 \mathrm{~m}$ of cores from six wells drilled in the Kristin Field. This field occupies the crestal part of an easterly tilted Jurassic fault-block, located in the western Halten Terrace. The authors stated that the Garn Formation was deposited in an actively subsiding, incipient graben within the narrow Jurassic seaway that existed at this time. The occurrence of conglomerates at the western extremity of the field (well 6506/11-3) supports the notion of a westerly sediment source area, which they termed the 'Grip High'. The Trøndelag Platform was a part of the seaway, but represented an area which at this time received little sand from the Norwegian shoreline (e.g., Doré, 1992; Brekke et al., 2001; Johannesen \& Nøttvedt, 2006). 
Deposition of the Garn Formation shows episodes of rapid progradation, which took place during periods of relative sea-level standstill or fall. These episodes are mainly dominated by shoreline and delta-front (mouth-bar) progradation, with local incursions of fluvial deposits (Gjelberg et al., 1987). Clinoforms recorded in the Garn Formation may represent prograding delta-front units along the western basin margin. The thickness of the steep foresets recorded is less than $10 \mathrm{~m}$. Clinoforms are also well developed within time-equivalent sediments in East Greenland, in both the Pelion and the Charcot Bugt formations, which represent prograding deltaic deposits (Larsen et al., 2003).

In East Greenland, a major change in basin configuration took place in mid-Bajocian time, as a response to the onset the Jurassic rifting episode (Surlyk, 2003). The rifting resulted in a major unconformity between the Neill Klinter Group and the overlying Varde Kløft Group. During the late Middle Jurassic, a major transgression took place and sediments started to onlap the unconformity. The basal onlapping succession, defined as the Pelion Formation (Engkilde \& Surlyk, 1993; Surlyk, 2003), is sand-dominated and exhibits similarities to the Garn Formation, with respect to both depositional environment and facies.

During deposition of the Garn Formation, coarse-clastic supply from the west was still active. However, during and following deposition of this formation, the land area west of the Halten Terrace became insignificant as a westerly source area. This is regarded as a result of deep erosion, but mainly that this land mass was transformed into a hanging wall position, west of the Klakk Fault Complex and associated with the Jurassic rift climax stage. As the land area to the west ceased to exist, leaving the narrow Sklinna Ridge as an easternmost remnant, virtually no input of coarse material from the west is encountered in Late Bathonian and younger sediments on the western Halten Terrace (Fig. 5). This stage of development, in this study, is interpreted as the first indication of the development of a large and continuous marine basin between Mid Norway and Greenland after the Caledonian Orogeny.

\section{Jurassic rift episode}

Jurassic extension affected the North Atlantic region, and at the end of the Jurassic, deep intra-continental rift basins existed from the Rockall Trough to the SW Barents Sea, with a separate branch into the North Sea (Ziegler, 1988; Lundin \& Doré, 1997; Roberts et al., 1999). Structural elements that evolved during the Jurassic rifting episode dominate the present-day structural configuration of the Norwegian Sea. The region subject to main Jurassic deformation, represents a c. $200 \mathrm{~km}$-wide zone, bounded to the east-southeast by the narrow Møre basement platform, Frøya High, Trøndelag Platform, Nordland Ridge and the Lofoten-Vesterålen archipelago (Fig. 1).

Tilted fault-blocks on the Halten and Dønna terraces and along the Møre and Lofoten-Vesterålen margins represent the most obvious expression of the Jurassic extension, and accordingly these areas provide the best data to constrain the duration of the rift episode. Jurassic rifting commenced in the Middle Jurassic (Blystad et al., 1995), and in later studies the base of the Jurassic syn-rift sequence was mapped as an intra-Bajocian reflector on the Halten Terrace (e.g., Corfield \& Sharp, 2000; Corfield et al., 2001; Messina et al., 2014). A Middle Jurassic rift initiation is consistent with observations from the northern North Sea (Færseth et al., 1995b; Færseth \& Ravnås, 1998) and the coastal area of East Greenland (e.g., Hartz et al., 2002; Surlyk, 2003; Hamann et al., 2005). Following an initial, Late Bajocian-Early Oxfordian rift stage characterised by modest fault-block rotation, the Late OxfordianVolgian represents the rift climax stage (Fig. 5) that created maximum topographic relief and water depths in half-grabens.

Beneath the Cretaceous Møre and Vøring basins, fault activity extended into the Early Cretaceous on a suite of large-displacement Jurassic faults that have been imaged in long-־offset seismic reflection 
data (e.g., Osmundsen et al. 2016; Osmundsen \& Péron-Pinvidic, 2018). As discussed below, authors disagree on whether Jurassic-Early Cretaceous faulting should be viewed as one continuous event or separated into distinct Late Jurassic and Early Cretaceous events (Lundin \& Doré, 1997; Doré et al., 1999; Osmundsen et al., 2002, 2016; Faleide et al., 2008; Osmundsen \& Péron-Pinvidic, 2018; Zastroshov et al., 2018).

East of the deep Cretaceous basins, syn-rift wedges are Jurassic in age and there is no convincing evidence of extended fault activity into the Early Cretaceous (Færseth \& Lien, 2002; Færseth, 2012). Well 6205/3-1R, drilled in the Slørebotn Sub-basin, penetrated and partly cored Lower CretaceousUpper Jurassic sediments in the hanging wall of a major NE-SW-striking fault zone along the Møre margin (Fig. 7). The well provides excellent data for the reconstruction of the fault-block rotation. Combining seismic interpretation and dip magnitude from the dipmeter log and core measurements, Jongepier et al. (1996) concluded that tilting of the fault-block was gentle during a Bajocian-Oxfordian initial rift stage. During the Kimmeridgian-mid Volgian, rotation accelerated to give the maximum dip at the base of the syn-rift succession of c. $50^{\circ}$ in the immediate hanging wall, due to the listric geometry of the fault zone. Lower Cretaceous sediments were deposited as downlapping sag-basin strata, followed by the overstepping and burial of the Gossa High in the Late Cretaceous.

For decades, authors have emphasised the importance of the base Cretaceous unconformity in the North Sea as well as the Mid-Norwegian shelf (e.g., Blystad et al., 1995: Brekke, 2000; Swiecicki et al., 1998; Osmundsen et al., 2016; Osmundsen \& Péron-Pinvidic, 2018). The unconformity has been considered as the transition from Jurassic rifting to a thermal subsidence stage and regarded as one of the most prominent sequence boundaries that apparently represents a hiatus of tens of millions of years. On seismic, Cretaceous sediments onlap Jurassic structural highs following a rise in the regional sea level. Up flank structural highs, the stratigraphic development that represents the Jurassic-Cretaceous transition might become complex with several hiatuses, as demonstrated in wells 6305/12-2 and $6306 / 10-1$ drilled in the Slørebotn Sub-basin. Accordingly, the so-called base Cretaceous unconformity is not necessarily a single unconformity, as considered by most authors, but rather several coalescing unconformities (Færseth et al., 1995b; Kyrkjebø et al., 2004).

Estimates of stretching factors have indicated that most of the extension in the distal area results from the Jurassic rifting episode, with an equal amount of crustal stretching beneath the Møre and Vøring basins. The amount of extension has been estimated based on fault heaves at top basement level and on bulk crustal thinning, respectively (e.g., Reemst \& Cloething, 2000; Skogseid et al., 2000; Gómez et al., 2004). Whereas the footwall cutoffs of large-magnitude faults are mapped with some confidence, it is difficult to identify the top-of-basement in the hanging wall of the faults. In some cases, the top of (seismic) basement in the hanging wall can be transported to a position tens of kilometres outboard of the breakaway (e.g., Manatschal, 2004; Osmundsen et al., 2016). Even though the horizontal displacement value of such faults is difficult to quantify, the amount of heave at top basement level for major faults is estimated to be in the range 15-40 km (e.g., Gómez et al. 2004; Osmundsen \& PéronPinvidic, 2018).

In distal parts of the investigated area, the relief at the base Cretaceous reflects underlying structures resulting from Jurassic extension, although modified by post-Eocene compression (Fig. 2). Beneath the Vøring Basin, Jurassic structures occur as N-S to NE-SW-trending rift basins and intervening highs, bounded by master faults (e.g., Blystad et al., 1995; Skogseid et al., 2000; Færseth \& Lien, 2002; Gómez et al., 2004). Zones characterised by maximum thinning of continental crust are located beneath the Rås and Træna basins and the Hel Graben (Fig. 1), where Cretaceous sediments apparently overlie basement (e.g., Breivik et al., 2011; Osmundsen et al., 2016). Also beneath the Møre Basin, the base Cretaceous outlines an irregular topography interpreted to represent major Jurassic fault-blocks at depth, with NE-SW as the principal trend for the structures (Graue, 1992; Blystad et al., 1995; Jongepier 
et al., 1996; Skilbrei et al., 2002; Gómez et al., 2004). Large, deep-seated structures such as the Grip and Vigra highs (Fig. 1), having basement as the assumed crestal part of the tilted fault-blocks (Skilbrei et al., 2002; Osmundsen et al., 2016), are capped by Upper Cretaceous sediments (Fig. 2A). Osmundsen et al. (2016) interpreted a minimum displacement in the order of 20-25 km on the fault zone that bounds the Vigra High in the northwest, with the deepest part of the Møre Basin and the thinnest continental crust located northwest of this high.

Associated with the Jurassic rift episode, the locus of rifting shifted from the $\mathrm{N}-\mathrm{S}$-oriented Sogn Graben in the northeasternmost North Sea and approximately $100 \mathrm{~km}$ to the east, to the oppositely tilted and N-S-trending Rås Basin in the Norwegian Sea (Fig. 1). The right-stepping shift of rifting took place across the paleo-basement high that represented the offshore extension of the Møre-Trøndelag Fault Complex. The Rås Basin dveloped in the hanging wall of the Jurassic Klakk Fault Complex. This fault complex, trending N-S, extends along strike for some $350 \mathrm{~km}$, having a throw down-tothe-west that in places exceeds $6 \mathrm{~km}$ at Mesozoic levels. Following Osmundsen \& Péron-Pinvidic (2018), the Klakk Fault Complex and the Ytreholmen Fault Zone define the outer necking breakaway complex, which separates the necking and distal domains in the SE Vøring Basin (Fig. 2). The Rås Basin became an area with thinning of the crust to $5 \mathrm{~km}$ or less and an elevated Moho (Skogseid et al., 2000; Osmundsen et al., 2002; Kjelstad et al., 2003; Gómez et al., 2004; Breivik et al., 2011; Osmundsen et al., 2016).

The regional NE-SW-trending and peneplaned basement highs that existed northwest and southeast of the deep basin area offshore Mid Norway (Færseth, 2012) became fragmented during the Jurassic rifting episode with the development of large and strongly rotated fault-blocks. Along the Lofoten-Vesterålen margin, fault-blocks bounded by basement-involved faults with throws of 3-5 km at top basement level represent the typical expression of Jurassic rifting (e.g., Blystad et al., 1995; Tsikalas et al., 2001; Bergh et al., 2007; Færseth, 2012; Hansen et al., 2012). Along the Møre margin, the most obvious expression of the Jurassic rifting is seen as fault-blocks beneath the Slørebotn Sub-basin (Fig. 7). However, remnants of the pre-existing basement high are preserved as several NE-SW-trending fault-blocks, such as the Manet Ridge, Selje, Gnausen, Giske and Ona highs (Fig. 1), which are all associated with the offshore extension of the Møre-Trøndelag Fault Complex.

The Slørebotn Sub-basin and Gossa High are separated from the narrow Møre platform by a large fault zone (Fig. 2A). This area represents the transition between moderately thinned basement crust in the footwall and a crust between 3 and $11 \mathrm{~km}$ thick below the hanging wall cutoff to the west (Osmundsen et al., 2016). The large-magnitude fault zone beneath the Slørebotn Sub-basin, with an intra-basement detachment to the west, defines a strongly rotated Jurassic fault-block c. $70 \mathrm{~km}$ wide (Fig. 7). The maximum vertical offset across this fault zone is $6-7 \mathrm{~km}$ at top basement level and the heave is $30-40 \mathrm{~km}$. This near-shore fault-block, with a good data coverage, appears comparable to Jurassic fault-blocks interpreted beneath the Møre and $\bigvee \emptyset r i n g$ basins, regarding size, fault geometry and the amount of heave.

During the Jurassic rift episode, the Halten Terrace evolved as a c. $70 \mathrm{~km}$-wide and easterly tilted structural entity along the eastern margin of the Vøring Basin. The structural development was governed by the Klakk, Vingleia and Bremstein fault complexes (Fig. 8), which were fundamental border faults in the Jurassic rift system. Jurassic extension resulted in a significant change in basin physiography, from a basin area with a relatively flat basin floor, encompassing the Trøndelag Platform and the Halten/ Dønna terraces, to a setting where the terraces evolved into separate structural entities, down-faulted with a basin-floor topography characterised by internal horsts, grabens and half-grabens (Figs. 8, 9). The boundary between the Halten and Dønna terraces is subtle, but according to Blystad et al. (1995) it is placed at $65^{\circ} 25^{\prime} \mathrm{N}$. 


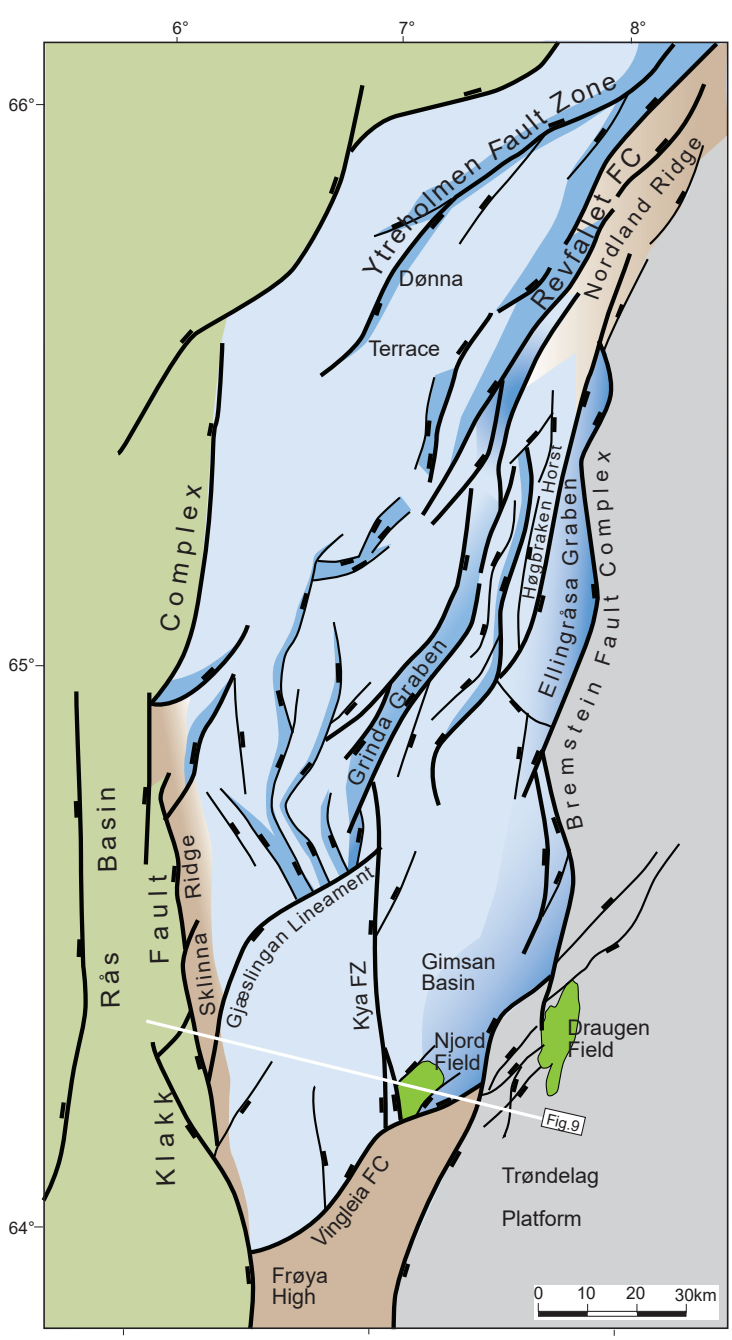

Figure 8. Map showing main structural elements of the Halten and Dønna terraces at Mid Jurassic level (blue colours). The grey colour represents the more stable Trøndelag Platform to the east, whereas the green colour shows the deep Jurassic Rås Basin to the west infilled by thick Cretaceous sediments. Due to Jurassic extension, the terraces were down-faulted, tilted, with internal horsts, half-grabens and grabens (dark blue). The Halten/Dønna terraces represent the Necking domain of the SE Vøring margin (Osmundsen \& Péron-Pinvidic, 2018), and the master faults that delineate the terraces to the east and west have been termed the Inner and Outer breakaway complex, respectively.
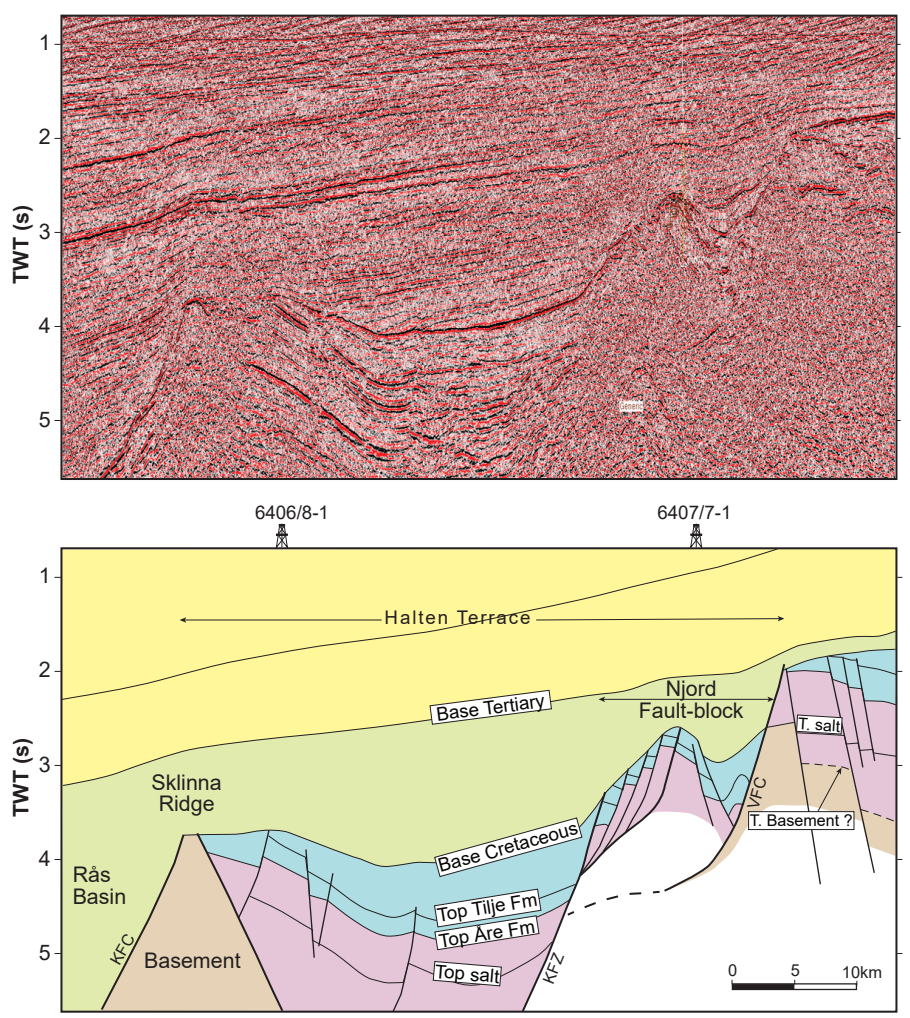

Figure 9. Profile showing the Halten Terrace as a major, easterly tilted, fault-block decoupled from the Trøndelag Platform during the Jurassic extensional episode. Location of profile in Fig. 8. In this profile, the Sklinna Ridge is bounded by a major fault to the east to form a narrow basement horst, capped by Cretaceous sediments. The Njord Fault-block with its complex fault pattern, developed in the hanging wall of a segment of the Vingleia Fault Complex (VFC), characterised by a ramp-flat-ramp geometry. Loading of thick Cretaceous sediments in the Vøring Basin resulted in the westerly tilt of sediments represented in this profile. KFC: Klakk Fault Complex, KFZ: Kya Fault Zone. 
The fault complexes bounding the Halten Terrace to the east, west and southeast, and large $\mathrm{N}-\mathrm{S}$-striking faults that outline major structures on the terrace, represent first- and second-order Jurassic faults. In addition, swarms of smaller normal faults, but above seismic resolution, are evident. Such faults, variably affected by underlying salt (e.g., Færseth \& Lien, 2002; Marsh et al., 2010), exhibit variations in strike direction, and cross-cutting relationships demonstrate that the faults represent different stages of development.

Late Ladinian-Carnian salt was deposited on the Trøndelag Platform, as well as on the Halten and Dønna terraces. In contrast to the Trøndelag Platform, salt became very influential on the Halten Terrace, regarding local thickness distribution and morphology of overlying sediments. Accentuated Jurassic rifting west of the platform evidently triggered the salt mobility. Several authors have described structures at Jurassic-Cretaceous levels as evidence of the strong influence of the underlying salt, but also as sub- and supra-salt structures decoupled by the salt interval (Jackson \& Hastings, 1984; Withjack et al., 1989; Pascoe et al., 1999; Corfield et al., 2001; Færseth \& Lien, 2002; Dooley et al., 2003; Richardson et al., 2005; Marsh et al., 2010; Wilson et al., 2013, 2015; Coleman et al., 2017).

The Gimsan Basin located in the SE Halten Terrace, in the hanging wall of the Bremstein Fault Complex (Fig. 8), is a large and elliptically shaped depression at base Cretaceous level (Blystad et al., 1995) that reflects major salt withdrawal. In the northwestern part of the Halten Terrace, several structures are related to salt movement. The eastern boundary fault of the narrow Grinda Graben has a relatively shallow NW-dipping detachment in the underlying salt, whereas oppositely dipping faults along the western boundary are generally joining up with the detachment. Færseth \& Lien (2002, figs. 10, 11), suggested latest Jurassic-Early Cretaceous W-SW translation of salt, and as a result, some faults above the salt demonstrate prolonged activity into the Early Cretaceous. The translation resulted in initial rafting and the development of a horst and graben topography, which is a characteristic style of deformation in the northwestern part of the terrace. Also, Marsh et al. (2010) interpreted continued deformation along faults in the northwestern part of the Halten Terrace, after the end of the Jurassic rift climax, and related these faults to salt movement and/or gravity sliding.

The N-S-striking Bremstein Fault Complex forms a relatively wide transition zone between the Halten Terrace and the Trøndelag Platform and is composed of horsts, grabens and rotated fault-blocks. The Ellingråsa Graben and Høgbraken Horst (Fig. 8) were described as internal (lower order) structural elements of the Bremsteinen Fault Complex (Blystad et al., 1995). Beneath the Triassic evaporite sequence, a basement-involved and west-dipping normal fault, planar in its upper part, represented a master fault along most of the length of the complex, although the amount of throw diminishes to the north (Elliott et al., 2012). Salt acted as a detachment between this fault at depth and faults above the salt (Færseth \& Lien, 2002; Wilson et al., 2013, Coleman et al., 2017). The lateral flow of salt across the fault zone resulted in an asymmetric flexure with normal as well as reverse faults above the salt, and faults show evidence of Late Jurassic as well as Early Cretaceous activity (Fig. 10).

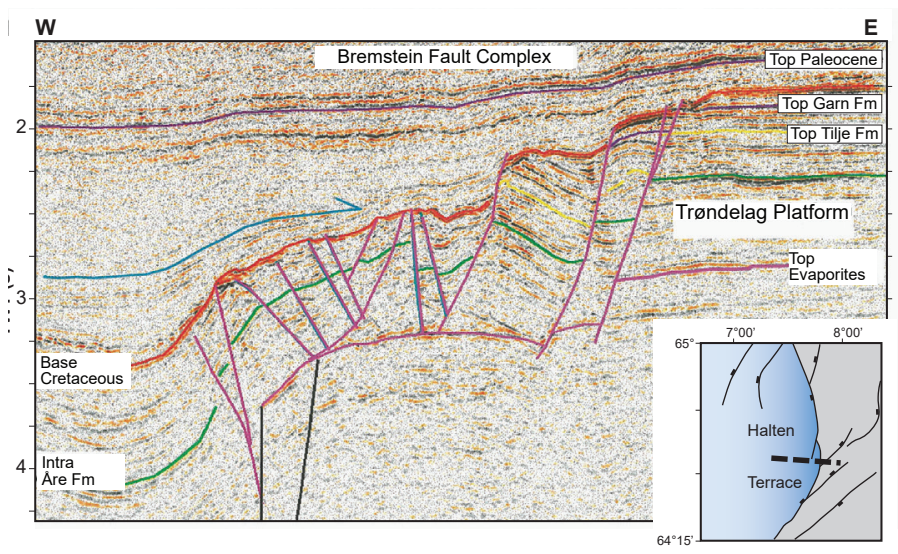

Figure 10. Seismic section across the wide transition zone between the Trøndelag Platform and the Halten Terrace, representing the Bremstein Fault complex. The thick Triassic evaporite succession acted as a detachment between a planar and basement-involved fault zone at depth and faults above the salt, which affected Jurassic and Cretaceous sediments. The lateral flow of the salt contributed to the asymmetric flexure, which became onlapped by Cretaceous sediments. 
The Vingleia Fault Complex is the boundary between the Frøya High and the Halten Terrace (Fig. 8). The fault complex is a NE-SW-trending structural element, but internal faults strike NE-SW, ENE-WSW and WNW-ESE. To the southwest, faults terminate in the area where they intersect the overall $\mathrm{N}-\mathrm{S}$ grain of the Klakk Fault Complex. To the northeast, faults of the Vingleia Fault Complex continue east of the Bremstein Fault Complex (Blystad et al., 1995). Elliott et al. (2015) described faults of the Vingleia Fault Complex as planar along large parts of its length, whereas a ramp-flat-ramp geometry becomes evident to the northeast. This fault geometry and the associated anticlines and synclines in the hanging wall (Fig. 9), have been known for decades, and published in earlier studies (e.g., Osmundsen et al., 2002; Ehrlich \& Gabrielsen, 2004). According to Osmundsen et al. (2016), a low-angle detachment representing this fault complex may continue to the west, underneath the southern part of the terrace.

The Njord fault-block in the SE Halten Terrace is associated with the ramp-flat-ramp geometry in the hanging wall of a NE-trending segment of the Vingleia Fault Complex, where the Njord Field occupies the crestal part of the fault-block (Figs. 8, 9). Seismic mapping reveals WSW-ENE, NE-SW and N-S as dominant fault orientations at Jurassic levels within the Njord fault-block. On the western flank of the fault-block, several N-S-striking normal faults, as part of the Kya Fault Zone (Fig. 8), merge at depth to define a listric fan (Fig. 9). Structural logging of cores from a number of wells drilled on the structure demonstrates a complex fault pattern and an extremely high frequency of sub-seismic faults, from $\mathrm{cm}$ scale up to $40 \mathrm{~m}$ of throw. The core data demonstrate that the largest sub-seismic Jurassic faults occur as up to $10 \mathrm{~m}$ wide zones, with fault displacement partitioned onto several slip surfaces (Færseth et al., 2007 , fig. 4). Such logging provides valuable information on faults at various scales, regarding their width, architecture, type of fault rock and how faults influence fluid flow within reservoirs.

\section{Jurassic rifting offshore and onshore Lofoten-Vesterålen}

Due to Jurassic extension, there was a change from the flat-topped basement high encompassing the Lofoten-Vesterålen archipelago and the shelf area to the northwest, to a topography characterised by a series of rotated fault-blocks (e.g., Blystad et al., 1995; Tsikalas et al., 2001; Bergh et al., 2007; Færseth, 2012; Hansen et al., 2012). Major Jurassic faults strike consistently NNE-SSW (Fig. 11), parallel to a main lineament trend onshore Lofoten-Vesterålen (Gabrielsen et al., 2002; Bergh et al., 2007) and with narrow fjords and sounds with this orientation, likely to have hosted Jurassic normal faults. The outcrop on Andøya, which contains Mesozoic sediments, forms the western flank of a Jurassic rift basin located beneath Andfjorden east of Andøya (Dalland, 1981).

During Middle Jurassic rift initiation, coeval with a relative sea-level rise, the eroded and peneplaned Precambrian basement was transgressed. The present Lofoten-Vesterålen archipelago was partly submerged during the initial rift stage, with deposition of Middle Jurassic syn-rift sediments in the deepest parts of the rift topography. The sampling of shallow-marine Bathonian-Middle Callovian sandstone in Vesterålsfjorden, NW of Hadseløy (Smelror et al., 2001), supports this notion. Beneath the Cretaceous Ribban Basin (Fig. 11) major Jurassic fault-blocks, typically 15-25 km wide, are bounded by basement-involved faults. The faults have throws in the range $3-3.5 \mathrm{~km}$, but locally reaching a maximum of $5 \mathrm{~km}$ (Vesterdjupet Fault Zone). The listric geometry of the faults reflects the strong influence of basement heterogeneities, likely to represent Caledonian thrusts and/or Devonian low-angle shear zones. The style of deformation, characterised by significant rotation of fault-blocks and the large heave across major normal faults (Fig. 12), demonstrate that faults along this margin accommodated significant Jurassic extension. Beneath the southwestern part of the Ribban Basin, the fault-blocks are tilted consistently ESE (Fig. 11) and the tilt at Jurassic level is 10-15 (Fig. 12A). To the northeast, there is a change and fault-blocks are tilted $16-25^{\circ}$ WNW (Fig. 12B). According to Færseth (2012), the change in dip of the faults and tilt of fault-blocks took place across a regional $\mathrm{E}-\mathrm{W}$-oriented basement lineament at $68^{\circ} 30^{\prime} \mathrm{N}$ (Fig. 11), and the structure resulting from the change of dip across the basement lineament was termed a low-relief accommodation zone (Fig. 12B). 


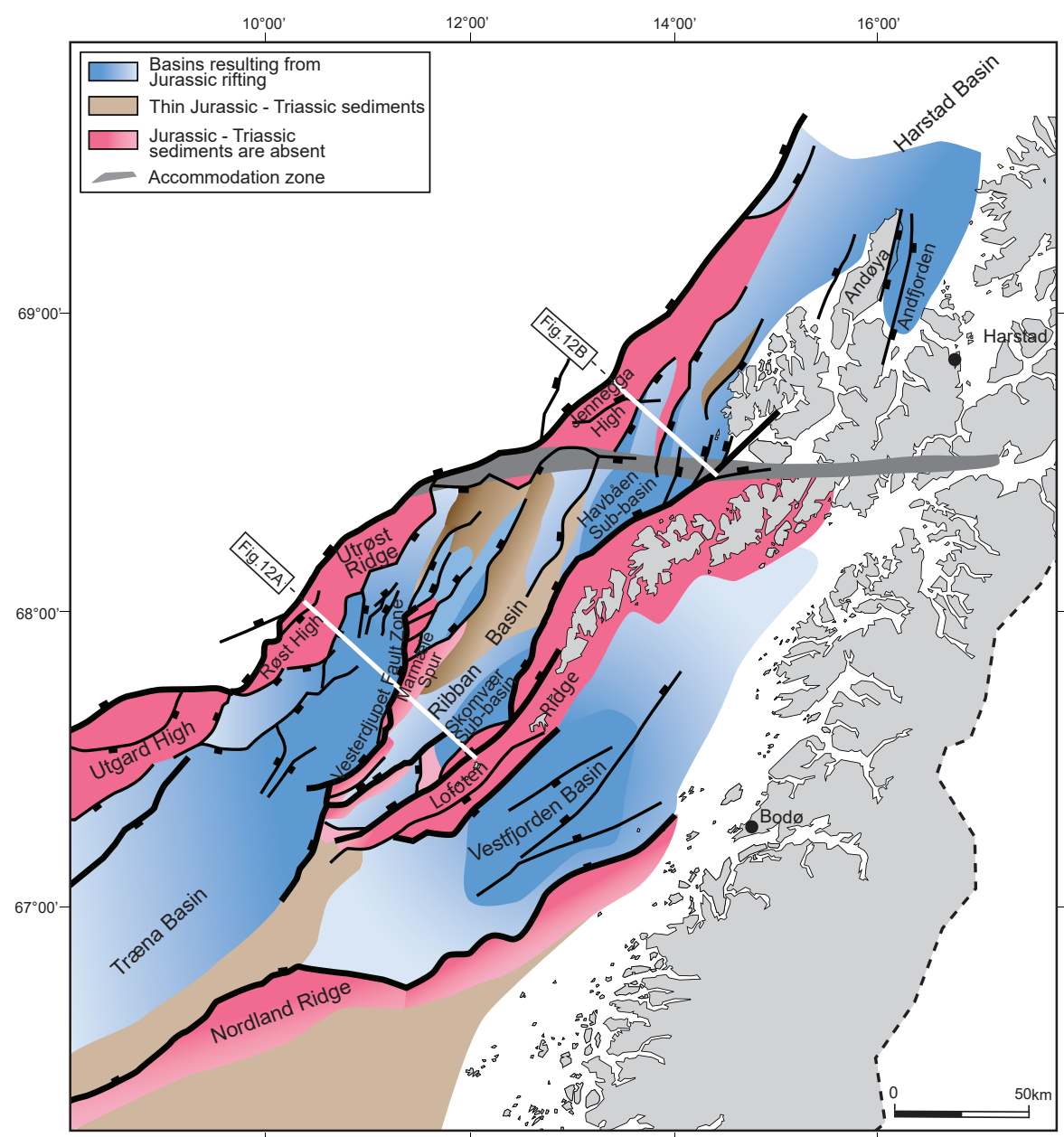

Figure 11. Jurassic structural elements in the Lofoten-Vesterålen margin are bounded by normal and basement-involved faults, which strike consistently NNE-SSW. Major Jurassic faults terminate within an accommodation zone at $68^{\circ} 30^{\prime} \mathrm{N}$, and the dip of faults as well as the tilt of Jurassic fault-blocks change across this zone. Campanian-Paleocene faults in the area strike NE-SW to E-W, oblique to the Jurassic faults. The outcrop on Andøya, which contains Jurassic-Cretaceous sediments above Precambrian basement, represents the western flank of a Jurassic rift basin situated beneath Andfjorden.
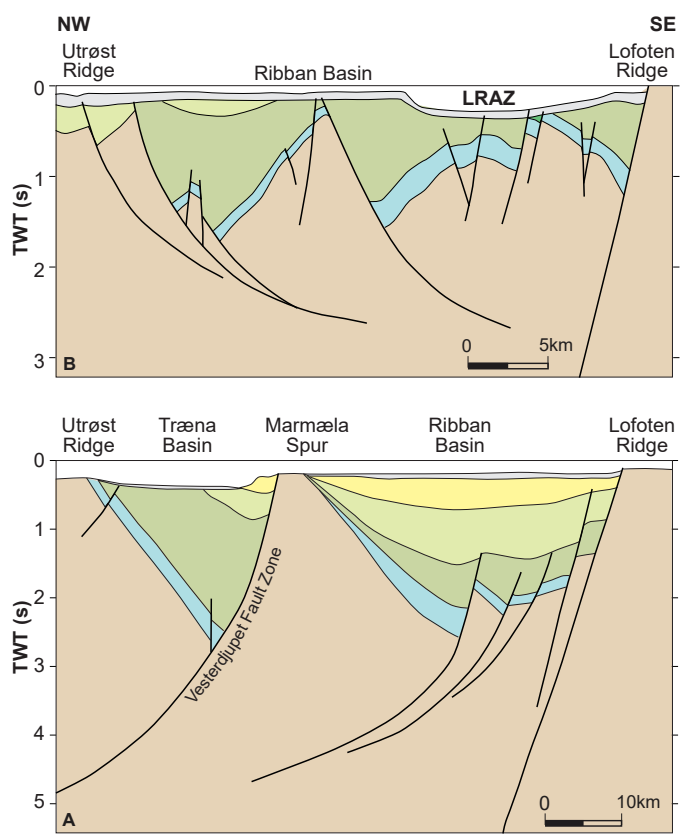

Figure 12. Geoseismic profiles showing the pronounced rotation offault-blocksin the hanging wallof basement-involved Jurassic faults. The profiles also demonstrate the change in dip of faults and the tilt of fault-blocks across the accommodation zone. Location of profiles in Fig. 11. Profile B across the accommodation zone shows the structure as a lowrelief accommodation zone (LRAZ) due to partly overlapping and oppositely dipping normal faults. Colours as in Fig. 3. 


\section{Jurassic syn-rift sedimentation}

The period defined as the initial rift stage encompasses the upper part of the Fangst Group (upper Garn Formation) and the lower part of the Viking Group (lower Melke Formation) (Fig. 5). The Garn Formation was deposited when the basin topography was still modest, and the formation that constitutes a potential reservoir is widely distributed in the eastern part of the Norwegian Sea, although usually less than $100 \mathrm{~m}$ in thickness. Bajocian-Bathonian sedimentation on the Halten Terrace occurred within a seaway, bounded to the west by the basement high. Due to initial Jurassic extension and faulting, the seaway comprised a series of incipient, shallow and N-S-trending grabens and half-grabens in the terrace area (Corfield et al., 2001; Bell et al., 2014; Messina et al., 2014).

The top of the Garn Formation is strongly diachronous, with a gradually younger and more coarse-grained development to the west and east compared to deposition in the axial part of the basin. At the southeastern basin margin (block 6206/2), Jurassic sediments encountered in shallow boreholes, adjacent to the Møre coastline, consist of conglomerates and sandstones, interpreted as alluvial-fan deposits (Smelror et al., 1994), and was assigned a Bathonian age by Jongepier et al. (1996). Along the western margin of the basin, conglomeratic facies are described as part of the Garn Formation on the western Halten Terrace (e.g., Gjelberg et al., 1987, Messina et al., 2014; Ravnås et al., 2014). To the southwest, Bathonian sediments with a thickness that varies from $150 \mathrm{~m}$ to more than 350 $\mathrm{m}$ have been encountered beneath the Slørebotn Sub-basin. The succession is composed of alternating sandstones, siltstones, claystones and subordinate conglomerates, and reflects an alluvial-fan/ flood-plain environment (Jongepier et al., 1996).

The coarse-clastic Bathonian sediments deposited along basin margins are partially time equivalent with offshore mudstones, interpreted as the lower part of the Melke Formation. Whereas the lower Melke Formation was deposited mainly in the central part of the basin, the upper part of the formation has a much wider areal distribution. The deposition of the Melke Formation shale succession was associated with the relative sea-level rise during the Bathonian (Dalland et al., 1988).

Middle-Upper Jurassic sediments with total thicknesses of 370 and $375 \mathrm{~m}$ are documented in shallow wells off Vesterålen (Hansen et al., 1992) and in the outcrop onshore Andøya (Dalland, 1975, 1979), respectively. The basal part is Bajocian-middle Callovian sandstones and mudstones, 120 and $125 \mathrm{~m}$ thick at the locations, deposited during an initial rift stage (Færseth, 2012; Hansen et al., 2012). The Bajocian-Callovian sediments, which onlap the Proterozoic basement west of Vesterålen (well 6814/ 04-U-01), confirm deposition of shallow-marine sandstones corresponding to the Garn Formation. On Andøya, a succession of fluvial, lacustrine and shallow-marine deposits of Bajocian-Bathonian (possibly up to Oxfordian) age, was described as the Ramså Formation (Dalland, 1975). Sediments in this area onlap deeply weathered basement rocks and the thin conglomerate at the base consists almost entirely of weathered basement showing the local provenance. The upper part of the Ramså Formation may correspond to a late margin onlap situation for the Garn Formation.

Deposition of the upper part of the Melke Formation and the overlying Spekk Formation took place during the late Oxfordian-Volgian rift climax stage. The upper part of the Melke Formation shows considerable variations in thickness on the Halten Terrace due to increasing structural relief. Due to the dramatic change in basin configuration during the rift climax stage, anaerobic bottom conditions prevailed all over the eastern part of the Norwegian Sea, leading to deposition of the bituminous Spekk Formation, which is the main source for proven hydrocarbons offshore Mid Norway. The formation is separated stratigraphically from the Melke Formation by a major hiatus or a condensed interval, where a part of the Kimmeridgian succession is missing (Fig. 5). 


\section{Syn-rift uplifts as source areas for coarse-clastic sediments}

Elevated areas offshore Mid Norway, such as the Sklinna and Nordland ridges, Frøya High and the footwall of the Bremstein and Vingleia fault complexes (Figs. 1, 8), were eroded during and following the Late Jurassic rift climax stage, leaving basement at relatively shallow levels and in places sub-cropping Cretaceous to Tertiary units. The deep erosion attests to Late Jurassic uplift in the order of 1-2 km in the footwall of large basement-involved faults bounding these highs (Roberts \& Yielding, 1991). The Rødøy High on the Nordland Ridge (Fig. 1) was subjected to deep erosion with removal of a thick Upper-Middle Triassic succession (Blystad et al., 1995), and might have acted as a major sediment source area after the uplift. A rough calculation indicates that some $3000 \mathrm{~km}^{3}$ of sediments were eroded above this high, of which c. $600 \mathrm{~km}^{3}$ were coarse clastics. However, the only coarser erosional products encountered are three-four tongues of late Bajocian-mid Bathonian, strongly bioturbated and muddy sandstones along the northeastern part of the ridge, together with Cretaceous sandstones, periodically deposited on the Dønna Terrace (Fjellanger et al., 2005; Lien, 2005; Fugelli \& Olsen, 2007). Most likely, erosional products from the Nordland Ridge were transported into the deep Vestfjorden and Træna basins (Fig. 1). Relatively thick but immature Lower Cretaceous coarse clastics encountered in well 6610/3-1R, drilled on the northern slope of the Nordland Ridge, are consistent with this assumption. Other wells drilled on the northwestern flank of the ridge (e.g., 6608/8-2, 6609/5-1) have also encountered Lower Cretaceous coarse-clastic deposits.

Due to Late Jurassic uplift in the footwall of the Vingleia and Bremstein fault complexes (Fig. 8), erosional products derived from both older sediments and basement rocks are evident. Coarseclastics were transported and redeposited either on the footwall high itself, or shed across fault scarps to be redeposited in the hanging wall of the large faults. Thick sandstone and conglomerate complexes in the Melke Formation have been drilled northwest of the Frøya High, in the hanging wall of the Vingleia Fault Complex. The coarse clastic sediments occur as braid plain deltaic deposits on the SE Halten Terrace (well 6406/12-1S), and as a c. 400 m-thick Oxfordian succession representing deep-marine debrites and turbidites in well 6406/12-2. In well 6407/10-1, a very spectacular coarsening-upwards succession of Oxfordian age consists of poorly sorted sandstone with floating pebbles, representing a rapidly prograding fan delta.

The Kimmeridgian-Volgian sandstone, Rogn Formation, was deposited on the Frøya High, but also farther to the northeast, where it represents the reservoir of the giant Draugen Field (Fig. 8). Wells drilled in hanging walls of the Vingleia and Bremstein fault complexes have encountered sand intervals of this generation (6407/10-1,6406/12-1S) to prove that some erosional products were shed across fault scarps and redeposited on the Halten Terrace. Wells which have penetrated the Rogn Formation in the footwalls exhibit a large variation in thickness, but $49 \mathrm{~m}$ is recorded in the type well 6407/9-1 (Dalland et al., 1988). The Rogn Formation is one of the best reservoirs on the Mid-Norwegian shelf with permeability up to several Darcys. In footwall areas, the formation represents elongated shallow marine bar systems, which developed into a submarine spit bar to the northeast. To the south, this bar system was connected to a braid delta system derived from the Frøya High. However, most of the sand probably originated from a major embayment to the southeast, transported northward by tidally induced longshore currents and redeposited as submarine bar complexes in the Draugen Field area (Gjelberg et al., 1987; Johannesen \& Nøttvedt, 2006). Above the southern margin of the Permo-Triassic Froan Basin, two shallow stratigraphic cores (6307/07-U-02 \& 03) encountered c. 80 metres of KimmeridgianVolgian sandstones within the Spekk Formation, interpreted as the Rogn Formation.

In East Greenland, in the Jameson Land Basin, the Oxfordian-Volgian Hareelv Formation is overlain by a Volgian, prograding, tidal-influenced, deltaic and shelf succession, named the Raukelv Formation (Surlyk \& Clemmensen, 1983; Surlyk, 1990, 2003), which corresponds to some of the Rogn sands on the Frøya High. Surlyk (2003) described remobilised Late Jurassic sandstone bodies of the Hareelv Formation. 
Similar remobilised Late Jurassic sand is not common on the Mid-Norwegian shelf but does occur in the shallow wells 6307/7-U-02 \& 03, where massive sands with flow lamination and associated injectites on top are present.

\section{Cretaceous development and influence of the inherited Jurassic rift architecture}

Whether the crestal parts of major tilted fault-blocks in the Norwegian Sea were close to sea level or represented large footwall islands at the termination of the Jurassic rifting episode is not well constrained, but water depths of thousands of metres are inferred to have existed in the deepest subbasins on hanging walls (Nelson \& Lamy, 1987; Young, 1992; Prosser, 1993; Rattey \& Hayward, 1993; Ravnås \& Steel, 1998; Færseth \& Lien, 2002; Bell et al., 2014). As major Jurassic fault-blocks were mostly located far from hinterland source areas, thin mud-dominated Upper Jurassic sediments accumulated in sediment-starved sub-basins (Nøttvedt et al., 1995; Ravnås \& Steel, 1998). Hence, Jurassic syn-rift successions represented only a minor constituent of the total sediment infill of the deep-water basins, and significant tectonic relief and water depths existed at the Jurassic-Cretaceous transition (Færseth \& Lien, 2002).

The thickness of the Cretaceous succession increases abruptly west of the Trøndelag Platform, reaching a maximum in the Møre and Vøring basins (Fig. 2). However, large Jurassic fault-blocks beneath the basins remained significant morphological features, as Upper Cretaceous sediments apparently cap basement in the crestal parts of the tilted fault-blocks. Due to lack of well control, some controversy exists regarding the thickness of Cretaceous sediments in the distal area. Based on the interpretation illustrated in the geoseismic profiles (Fig. 2), Cretaceous sediments reached thicknesses (after compaction) of some 7-9 $\mathrm{km}$. However, authors have suggested that Cretaceous sediments in the deepest sub-basins of the Møre and Vøring basins might have achieved thicknesses approaching 12-15 km (e.g., Faleide et al., 2008; Osmundsen et al., 2016; Zastrozhnov et al., 2020).

After some 60-65 million years of sedimentation, the topographic relief became levelled causing depocentres of the Late Jurassic-Early Cretaceous to merge into wider depocentres (Fig. 2). Upper Cretaceous sediments onlap older strata along the eastern margin of the Vøring Basin as a result of the westerly tilt on the Mid Norwegian continental shelf due to post-rift thermal subsidence and sediment loading (Færseth \& Lien, 2002).

Along the Lofoten-Vesterålen margin, the pronounced tilting $\left(15-25^{\circ}\right)$ of $15-25 \mathrm{~km}$-wide Jurassic fault-blocks resulted in water depths of more than $2000 \mathrm{~m}$. Also in this area, Jurassic syn-rift sediments represent only a minor constituent of the total sediment infill (Fig. 12). It was not until the Late Cretaceous that the Jurassic rift topography in this area was levelled, causing the different depocentres, initially represented by NNE-SSW-oriented half-grabens (Fig. 11), to merge into a wider and NE-SWtrending depocentre, i.e., the Cretaceous Ribban Basin (Færseth, 2012).

\section{Early Cretaceous sedimentation in the near-shore area}

During the Early Cretaceous, mud deposition is assumed to have dominated in deep-water basins to the west (Færseth \& Lien, 2002; Lien, 2005). In contrast, the Trøndelag Platform was a relatively shallow-water, low-topography shelf area, with the Nordland Ridge as an exposed and potential sediment source area and the Cretaceous Helgeland Basin (Blystad et al., 1995) as a topographic low (Fig. 1). During the relative sea-level rise in the late Berriasian and through the Valanginian-Hauterivian, sediments representing the Lyr Formation (Dalland et al., 1988) were deposited. 
The large number of wells drilled in the eastern basin area demonstrate the variation in thickness and composition of the Lyr Formation. Most wells reveal a thickness less than $50 \mathrm{~m}$, and as the formation covers a considerable time span (Fig. 5), the rate of sedimentation was extremely low. The Lyr Formation is locally absent on the Trøndelag Platform, and above some highs on the basin floor the whole of the Lower Cretaceous (Cromer Knoll Group) is missing. In wells on the southeastern margin of the Nordland Ridge, towards the Dønna Terrace and on the eastern Halten Terrace, the thickness of the Lyr Formation exceeds $200 \mathrm{~m}$ (Fig. 2C). In the Helgeland Basin (Fig. 4C), thicknesses up to $500 \mathrm{~m}$ are proven, as in wells 6510/2-1 and 6610/7-1, and sediments were most likely sourced from the Norwegian mainland.

The Lyr Formation exhibits sediments and depositional environments that range from shallow-marine carbonate and sandstone to deep-marine mudstone and marl. As sediments derived from local source areas did not enter far into the basin, it resulted in an underfilled state with condensed intervals and carbonate deposition (Dalland et al., 1988; Lien, 2005). Sand-rich sediments were trapped in localised basins, such as the Helgeland Basin and the Slørebotn Sub-basin (Larsen et al., 2001; Möller et al., 2004; Lien, 2005; Martinsen et al., 2005).

Shallow drillcores west of the Lofoten Ridge (wells 6710/03-U-01, 6711/04-U-01) have penetrated Lower Cretaceous sediments less than $100 \mathrm{~m}$ in thickness, whereas a $20 \mathrm{~m}$-thick interval was encountered offshore Vesterålen (well 6814/04-U-02) (Hansen et al., 1992). The thickness of Lower Cretaceous sediments increases rapidly to the southwest into the Træna and Vestfjorden basins, where thicknesses might have exceeded $2000 \mathrm{~m}$ in both basins (Figs. 2C, 3). Onshore Andøya, a BeriasianValanginian shallow-marine and sand-prone unit c. $40 \mathrm{~m}$ in thickness was associated with a major transgression (Dalland, 1979) and represents an equivalent to the Lyr Formation.

\section{Cretaceous basin development in the Norwegian Sea}

Over the years, authors have suggested Cretaceous tectonic events in the Norwegian Sea, primarily involving extension, but also compression, salt tectonics and strike-slip movements (Gowers \& Lunde, 1984; Price \& Rattey, 1984; Caselli, 1987; Ziegler, 1988; Grønlie \& Torsvik, 1989; Blystad et al., 1995; Bjørnseth et al., 1997; Lundin \& Doré, 1997; Brekke et al., 1999, 2001; Doré et al., 1999; Gabrielsen et al., 1999; Pascoe et al., 1999; Roberts et al., 1999: Brekke, 2000; Skogseid et al., 2000; Bugge et al., 2002; Osmundsen et al., 2002, 2016; Fjellanger et al., 2005; Faleide et al., 2008). Due to a lack of precision regarding timing, the large number of events invoked spans most of the Cretaceous period.

Færseth \& Lien (2002) presented a summary and discussion of published and contrasting tectonic events. However, also in more recent publications there is still no consensus about timing, the amount of extension and the regional importance of suggested Cretaceous tectonic events (e.g., Osmundsen et al., 2016; Theissen-Krah et al., 2017; Osmundsen \& Péron-Pinvidic, 2018; Zastroshnov et al., 2018, 2020; Tsikalas et al., 2019).

Doré et al. (1999) claimed that Cretaceous deformation in the Norwegian Sea resulted from two extensional events, the first in the Early Cretaceous (Neocomian) and the second in the Middle Cretaceous. Due to northeastward propagation of Cretaceous crustal stretching, a continuous chain of deep basins from the Rockall Trough to the SW Barents Sea was supposed to overprint older basins. Osmundsen et al. (2002) inferred Early Cretaceous extension and fault activity in the Norwegian Sea, which were at a maximum within the Møre and Vøring basins. Zastroshnov et al. (2020) claim that the Early Cretaceous to Paleocene evolution of these basins is associated with episodic phases of extensional events separated by intermediate cooling phases and that the two basins have different structural and sedimentary evolution. 
Published interpretations of deep-seismic profiles indicate that the Møre and Vøring basins are hosting large-magnitude Jurassic normal faults with sub-horizontal detachments, and authors have suggested Early Cretaceous extensional reactivation on faults of Jurassic origin (e.g., Osmundsen et al., 2016; Theissen-Krah et al., 2017; Osmundsen \& Péron-Pinvidic, 2018; Zastroshnov et al., 2018, 2020). Due to Jurassic crustal stretching, lithologies were subject to displacements of tens of kilometres, from the footwall cutoff to their inferred position in the hanging wall. Hence, attempts to quantify subsequent Cretaceous horizontal displacement (heave), associated with such faults, become highly speculative and accordingly the amount of Early Cretaceous extension is poorly constrained.

There has also been some controversy over whether this evolution should be viewed as one continuous event, or separated into distinct Late Jurassic and Early Cretaceous events (Lundin \& Doré, 1997; Doré et al., 1999; Faleide et al., 2008; Osmundsen et al., 2016; Zastroshnov et al., 2018, 2020). Observations of the Volgian Spekk Formation, unconformably overlying older sediments above the Gossa High (well 6305/12-2) and Frøya High (well 6407/10-3), demonstrate that the Jurassic rift episode ended intra-Volgian, and accordingly was separated from postulated Cretaceous tectonic activity. Some authors have suggested that Early Cretaceous fault activity became younger towards the northwest (Osmundsen et al., 2002, 2016; Osmundsen \& Péron-Pinvidic, 2018). A prolonged fault activity in the distal domain, compared to the proximal domain, has been attributed to a change from a stretching mode to a thinning mode of deformation, respectively (Theissen-Krah et al., 2017; Zastroshnov et al., 2018).

Based on suggested effects of Cretaceous rifting in the Møre and Vøring basins, the structural development of these deep basins appears different from adjoining areas, both to the west and to the east. Onshore East Greenland, Cretaceous siliciclastic marine sediments overlie the degraded Jurassic rift topography. Faults and unconformities mapped within the Early Cretaceous succession led workers to suggest several extensional events (e.g., Surlyk et al., 1981; Kelly et al., 1998; Larsen et al., 2001; Parsons, 2017). Whitham et al. (1999) claimed that Early Cretaceous extensional events were not well constrained, and according to these authors the total extension associated with Early Cretaceous normal faulting is very modest, estimated to be 3 percent. Surlyk \& Noe-Nygaard (2001) stated that postulated extensional events are generally related to deposition of breccias and conglomerates, and some of these deposits represent downslope sliding and slumping along discrete detachment planes, i.e., they result from gravity collapse and were not associated with rift-related faulting.

In the eastern part of the Norwegian Sea, workers have regarded thickness variations across normal faults, wedge-shaped sedimentary bodies, onlap surfaces and the observation of the base Cretaceous reflection being offset by large faults, as evidence of Early Cretaceous extension. The large number of sub-basins northwest of the Lofoten-Vesterålen archipelago, which exhibit wedge-shaped Early Cretaceous geometries (Fig. 12), are regarded as syn-rift deposits (e.g., Mokhtari \& Pegrum, 1992; Løseth \& Tveten, 1996; Lundin \& Dóre, 1997; Doré et al., 1999; Smelror et al., 2001; Tsikalas et al., 2001; Wilson et al., 2006; Bergh et al., 2007; Hansen et al., 2012). In comparison, thick wedge-shaped Cretaceous successions in the northern North Sea have for decades been regarded as post-rift deposits and the infill of deep-water basins following the Jurassic rift episode (e.g., Badley et al., 1988; Færseth et al., 1995b; Gabrielsen et al., 2001; Kyrkjebø et al., 2004; Morisbak Jarsve et al., 2014). Færseth (2012) interpreted the wedge shape of Lower Cretaceous successions along the Lofoten-Vesterålen margin segment as postrift infill of tilted Jurassic fault-blocks. Onlap surfaces against fault-scarps, later deformed by compaction, which is common in the area, show the progressive sedimentary infill of the deep-water sub-basins.

Based on a study of the southern Lofoten margin, Tsikalas et al., (2019) introduced three main rift phases from Mid Cretaceous to Paleocene. Henstra et al. (2016, and references therein), based on a study in the same area, stated that Valanginian-Aptian deposits onlap onto the base Cretaceous unconformity in a time-transgressive manner. Accordingly, their depositional environment was interpreted to be sediment-starved, with the passive infill of seafloor depressions inherited from the Late Jurassic rift 
climax stage. As these basins had not been filled in, they continued to subside during the Early Cretaceous in response to compaction of Jurassic deposits and thermal subsidence, i.e., in a fashion similar to the model proposed by Færseth \& Lien (2002).

These authors argued that the Cretaceous sedimentation in the Norwegian Sea, until the onset of Campanian rifting, represented a post-rift thermal subsidence stage, and emphasised the importance of the pre-existing Jurassic rift architecture, with significant tectonic relief and water depths following the rifting episode. Variations in sedimentation rate, the types of sediment deposited and thickness distributions were interpreted to reflect variations in sea level during infilling of the Jurassic rift topography, as well as responses to post-rift thermal subsidence, sediment loading and differential compaction during burial. The onlap of Cretaceous horizons along pre-existing fault scarps, later deformed by compaction, demonstrate the progressive post-rift sedimentary infill of deep-water basins (Fig. 13). Due to the continuous compaction of Late Jurassic-Early Cretaceous mud-dominated sediments on the hanging wall, Jurassic fault planes continued to grow and propagate up through the overlying sediments, which caused upturn of reflectors and compaction-induced faulting (Fig. 13). This type of 'drape-slip' faulting (Bertram \& Milton, 1989) is not an indication of extension, but is commonly associated with the thermal subsidence stage.

Multiphase rift systems, in which tectonic episodes alternate with extended periods of tectonic quiescence and subsidence on a regional scale, can be expected to host a wide range of depositional environments over time as relationships between sediment supply, sea level and subsidence repeatedly shift (e.g., Ravnås et al., 2000; Færseth \& Lien, 2002; Withjack et al., 2002). Authors have demonstrated that ignoring the importance of the remnant rift topography can lead to overestimation of the duration of active faulting (e.g., Bertram \& Milton, 1989; Prosser, 1993; Færseth et al., 1995b; Doglioni et al., 1998; Færseth \& Lien, 2002).

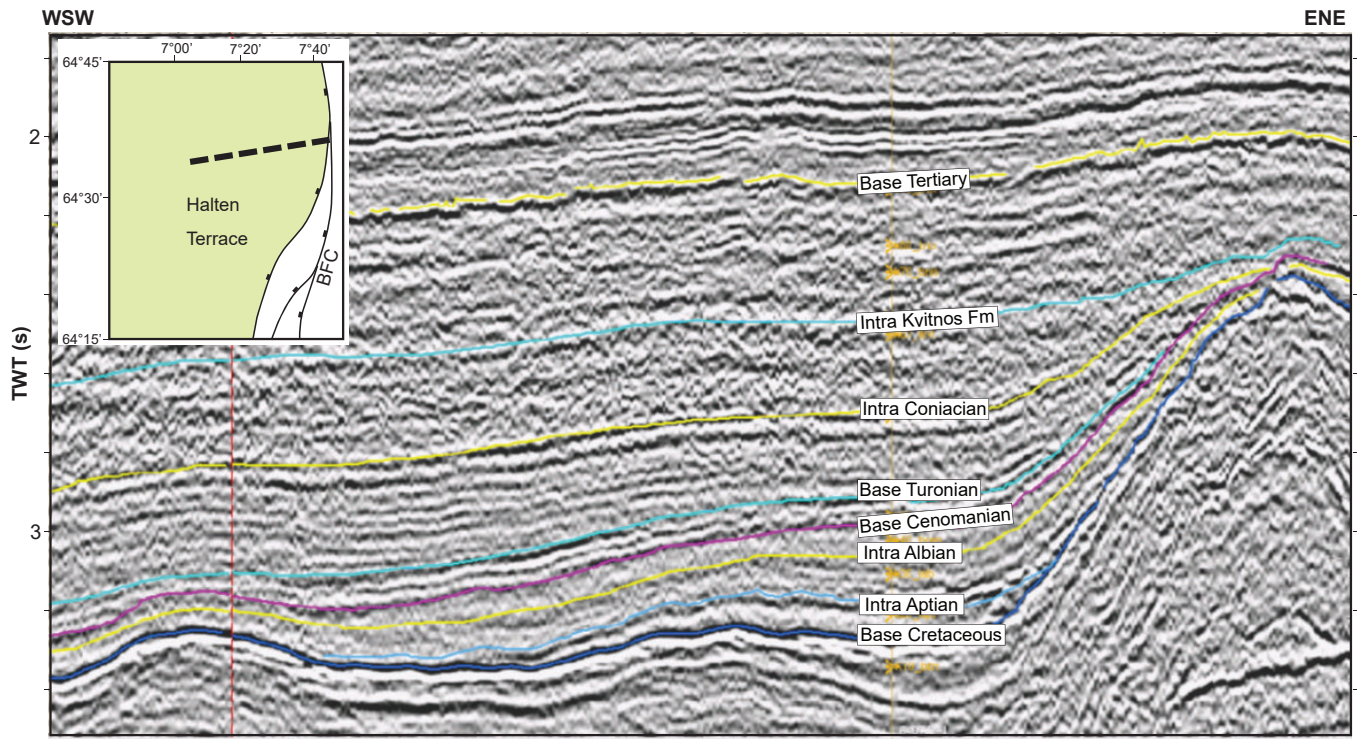

Figure 13. Seismic section showing Cretaceous sedimentation on the Halten Terrace, which infilled the pre-existing Late Jurassic rift topography in the hanging wall of the Bremstein Fault Complex (BFC). Due to loading and compaction, mud-dominated sediments were dragged up the fault scarp and subsequently onlapped by younger deposits. The topography created by Jurassic extension and faulting was levelled during the Late Coniacian, i.e., some 60 million years after Jurassic faulting had ceased. 


\section{Campanian-Paleocene rift episode}

Effects of this rifting episode are most apparent in the northwestern part of the Vøring Basin, where rifting was terminated by the crustal separation between Greenland and Eurasia at the PaleoceneEocene boundary (e.g., Skogseid \& Eldholm, 1989; Roberts et al., 1999). In contrast to the Møre and Vøring basins, the breakup along the Lofoten-Vesterålen margin occurred on the southeast flank of the wide Late Cretaceous basin between Norway and Greenland (Fig. 1).

An Early Campanian rift initiation at around 82-80 Ma offshore Mid Norway (Færseth \& Lien, 2002; Ren et al., 2003) is consistent with observations along the Lofoten-Vesterålen margin (e.g., Tsikalas et al., 2001). Færseth \& Lien (2002) and Ren et al. (2003) divided the rifting episode into an initial and a rift climax stage (Fig. 5). The Campanian initial rift stage, characterized by large-scale normal faulting (Fig. 14), controlled sediment thickness variations in the NW Vøring Basin (Blystad et al., 1995; Swiecicki et al., 1998; Skogseid et al., 2000; Gómez et al., 2004; Lien, 2005). The rift climax stage (Maastrichtian-Paleocene) was associated with continued extension, extensive volcanic activity, regional uplift and subsequent erosion (Kelly et al., 1998; Brekke et al., 1999; Gjelberg et al., 2001; Larsen et al., 2001; Gernigon et al., 2020; Zastrozhnov et al., 2020). A decrease in magma volume along the Lofoten-Vesterålen margin is evident (Eldholm \& Grue, 1994; Tsikalas et al., 2001).

Since the study by Talwani \& Eldholm (1972), the large-scale geodynamic processes and nature of the breakup in the Norwegian-Greenland Sea have been extensively debated (e.g., Talwani \& Eldholm, 1977; Eldholm et al., 1989; Skogseid \& Eldholm, 1989; Skogseid et al., 1992, 2000; Blystad et al., 1995; Bjørnseth et al., 1997; Lundin \& Doré, 1997; Ren et al., 1998, 2003; Swiecicki et al., 1988; Berndt et al., 2001; Lundin \& Doré, 2002, 2011; Mjelde et al., 2001, 2005, 2007; Gernigon et al., 2003, 2004, 2015, 2020; Manatschal et al., 2004; Osmundsen \& Ebbing, 2008; Péron-Pinvidic et al., 2012, 2013; Nirrengarten et al., 2014; Osmundsen et al., 2016; Péron-Pinvidic \& Osmundsen, 2016, 2018; Theissen-Krah et al., 2017; Osmundsen \& Péron-Pinvidic, 2018; Zastrozhnov et al., 2018, 2020).

Gernigon et al. (2015) suggested that the magmatic breakup in the Norwegian-Greenland Sea was diachronous and initiated as isolated and segmented sea-floor spreading centres in the Early Eocene, an assumption supported by Péron-Pinvidic \& Osmundsen (2018). The final line of lithospheric breakup may have been controlled by highly oblique extension (Gernigon et al., 2020). Volcanic features in the outermost margin have been variably interpreted as intrusions, underplating, lava flows and hyaloclastic deltas (e.g., Blystad et al., 1995; Berndt et al., 2001; Gernigon et al., 2004; Theissen-Krah et al., 2017). Significant uplift and erosion to the northwest have been attributed to the breakup processes and/or the impact of the Iceland plume (e.g., Skogseid et al., 1992; Ren et al., 1998; Mjelde et al., 2007).

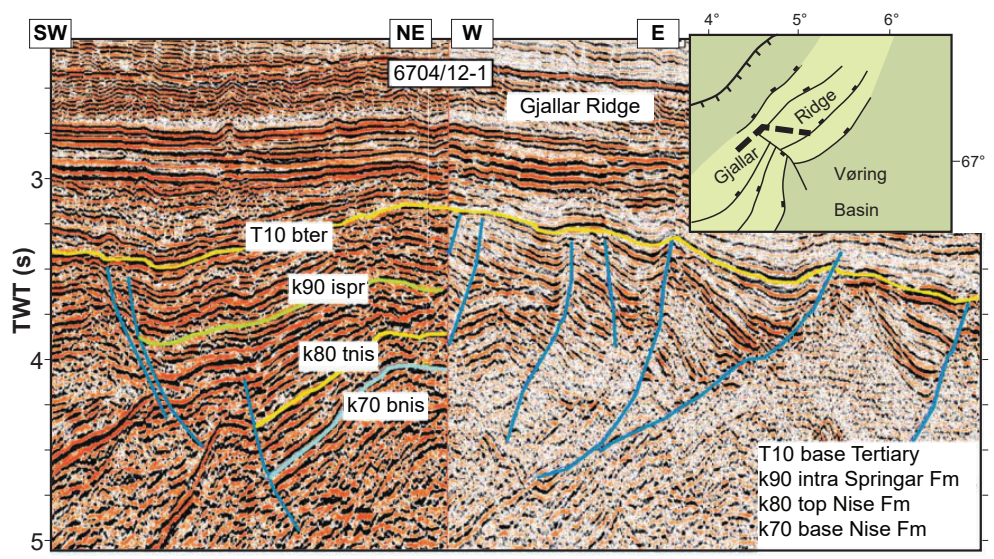

Figure 14. The Gjalla Ridge as a major uplift in the NW Vøring Basin. Normal faults and associated syn-rift wedges indicate Early Campanian initiation of the final extensional episode in the Norwegian Sea. 
The outer Vøring Basin is a complex system of faulted ridges, located between a deep Cretaceous basin to the southeast and the Vøring Marginal High to the northwest, which delimits the oceancontinent transition (Fig. 1). Based on long-offset seismic reflection data, a number of very large faults have been interpreted at depth and defined as an outer breakaway complex (Osmundsen et al., 2016; Péron-Pinvidic \& Osmundsen, 2016).

The outer ridge system of the Vøring margin was defined as the Gjallar Ridge (Fig. 1) (Blystad et al., 1995), which consists of NE-SW-trending, deeply eroded and rotated fault-blocks (Figs. 2B, 14). Osmundsen \& Péron-Pinvidic (2018) interpreted ridges and highs, inboard of the line of breakup, to be associated with the outer breakaway complex. The growth of the Gjallar Ridge, has been regarded as the most pronounced Late Cretaceous structural development offshore Mid Norway (e.g., Blystad et al., 1995; Bjørnseth et al., 1997; Ren et al., 1998; Swiecicki et al., 1998; Brekke et al., 2001; Osmundsen et al., 2016). The northwestern flank of the ridge is partly masked by Tertiary lava flows, and along the top of the ridge sediments were eroded, leaving a prominent unconformity at the base of the Tertiary succession. Major Late Cretaceous-Paleocene, NW-dipping normal faults, evident at the top of the ridge (Figs. 2B, 14), flatten down-dip at 6 seconds TWT (e.g., Ren et al., 1998; Gómez et al., 2004).

Along the southeastern flank of the Gjallar Ridge, pre-Tertiary sediments thicken and dip gently into the Vigrid Syncline (Fig. 2B). The southeastward descent of this stratigraphy indicates a deep location of the base Cretaceous in the deepest parts of the structure (Osmundsen et al., 2016). Within the Cretaceous succession, workers have identified a regional onlap unconformity, assumed to be associated with growth of the Gjallar Ridge (e.g., Blystad et al., 1995; Swiecicki et al., 1998; Doré et al., 1999; Brekke et al., 2001; Færseth \& Lien, 2002). Well 6603/5-1, drilled on the SW Gjallar Ridge, has TD at $5454 \mathrm{~m}$ in the Cretaceous Lange Formation, and revealed an intra-Aptian age for the unconformity. Accordingly, there is evidence of uplift that predated the Campanian-Paleocene rift episode, although final uplift and erosion of the ridge were associated with this rifting episode.

The Fles Fault Complex, which subdivides the Vøring Basin (Fig. 1), is assumed to have played an important role in the Cretaceous development, and several phases of movement have been attributed to this fault complex (e.g., Blystad et al., 1995; Bjørnseth et al., 1997; Lundin \& Doré, 1997; Doré et al., 1999; Brekke, 2000; Fjellanger et al., 2005; Osmundsen et al., 2016; Osmundsen \& PéronPinvidic, 2018). The Fles Fault Complex, as well as some other major normal faults in the Møre and Vøring basins, were subject to post-Eocene reverse reactivation, and accordingly the timing and amount of fault displacement are not well constrained. However, as major faults affecting Cretaceous sediments exhibit comparable amounts of offset from top Cretaceous and downwards (Fig. 2B, C), the main activity as normal faults most likely results from the Campanian-Paleocene rift episode (e.g., Brekke, 2000; Færseth \& Lien, 2002). A study by Fjellanger et al. (2005) supports this notion, as it shows onlap of the Maastrichtian Springar Formation in the easterly tilted footwall of the Fles Fault Complex.

Pronounced effects of post-Jurassic faulting are evident in the northeastern part of the investigated area. Beneath the Ribban Basin (Fig. 11), Jurassic rift architecture became modified by later fault activity, seen as rejuvenation of dip-slip movements within fault zones initiated during Jurassic rifting, but also as faults that transect large Jurassic fault-blocks to create smaller compartments (Færseth, 2012). The precise timing of fault activity is not well constrained due to deep erosion and the overall absence of Upper Cretaceous-Tertiary sediments. However, as this margin segment was close to the continent separation, significant faulting activity prior to breakup, similar to the Vøring margin, is anticipated. Hence, the latest fault activity in the area is inferred to result from the Campanian-Paleocene rifting episode (Mokhtari \& Pegrum, 1992; Blystad et al., 1995; Løseth \& Tveten, 1996; Doré et al., 1999; Tsikalas et al., 2001; Bergh et al., 2007; Færseth, 2012; Hansen et al., 2012). 
The faults northwest of the Lofoten-Vesterålen archipelago, regarded to have resulted from the Campanian-Paleocene rift episode, strike NE-SW to E-W. Fault zones of this generation bound the Cretaceous Ribban Basin, and are clearly oblique to the NNE-SSW-striking Jurassic faults (Fig. 11). Færseth (2012) suggested that the characteristic zigzag pattern of fault zones along strike is due to large NNE-SSW-oriented Jurassic faults that became linked by ENE-WSW to E-W-striking fault segments during Campanian-Paleocene extension, to result in the overall NE-SW orientation. Accordingly, prominent basement lineament trends, oriented NNE-SSW and ENE-WSW to E-W, which are evident both offshore and onshore Lofoten-Vesterålen (Gabrielsen \& Ramberg, 1979; Olesen et al., 1997, 2002; Gabrielsen et al., 2002; Bergh et al., 2007), were utilised during the Jurassic and CampanianPaleocene rift episodes, respectively. A NE-SW to ENE-WSW orientation for Campanian-Paleocene faults is consistent with the change from $\mathrm{E}-\mathrm{W}$ to the $\mathrm{NW}$-directed absolute plate movement at around $85 \mathrm{Ma}$ (Torsvik et al., 2001; Mosar et al., 2002; Torsvik \& Cocks, 2005).

\section{Campanian-Paleocene syn-rift sedimentation}

During the rifting episode, there was a change from the Late Cretaceous basin-wide sedimentation in the Vøring Basin, to deposition in progressively more localised and fault-controlled basin lows (Fig. $2 B, C)$. Over the last decades, deep-marine sandstones deposited in the Norwegian Sea, associated with the rifting episode, have become important in exploration as well as reservoir production (e.g., Vergara et al., 2001; Fjellanger et al., 2005; Lien, 2005). The giant Ormen Lange Field, located in the SE Møre Basin and producing from Paleocene sandstones (e.g., Gjelberg et al. 2001; Möller et al., 2004), as well as smaller discoveries (e.g., Nyk; Kittelsen et al., 1999; Fjellanger et al., 2005), contain good-quality reservoir sandstones. Several wells, however, have failed to reveal the predicted reservoir (Lien, 2005).

Upper Cretaceous-Paleocene sandstones deposited in the Vøring Basin were sourced mainly from East Greenland (Fjellanger et al., 2005; Lien, 2005; Morton et al., 2005; Parsons et al., 2017). Coarse clastics were focused by NW-SE-trending lineaments and transported across the narrow shelf into the Vøring Basin, where they were deposited as sand-rich, deep-marine fans in a thick (>1000 $\mathrm{m}$ ) succession (Whitham et al., 1999; Vergara et al., 2001; Fjellanger et al., 2005; Lien, 2005). The Lower Campanian sequence varies dramatically in thickness, from a more than 800 m-thick sandstone on the Nyk High (Fig. 1) (Kittelsen et al., 1999: Fjellanger et al., 2005), to a c. 200 m-thick mudstone succession in the SE Vøring and Møre basins, and less than $200 \mathrm{~m}$ on the Halten Terrace (Færseth \& Lien, 2002) (Fig. 2B, C).

During the rift climax stage, the Norwegian mainland became a source for sandstones, i.e. the Tang Formation (Fig. 5). Deposits of this generation are represented by the c. $700 \mathrm{~m}$-thick, sand-rich, Vestfjorden fan (Fonneland et al., 2004; Lien, 2005), and the up to $100 \mathrm{~m}$-thick Ormen Lange fan in the SE Møre Basin (Brekke et al., 1999; Martinsen et al., 1999, 2005; Gjelberg et al., 2001; Möller et al., 2004; Lien, 2005). On the Lofoten margin, an inter-basinal turbidity system formed in response to uplift of the Utrøst Ridge during the Paleocene (Henstra et al., 2016). These workers suggested that the SW-directed turbidity system of this margin might have continued into the Vøring margin, where a series of $\mathrm{S}$ - to SW-directed turbidite systems delivered sand to the Någrind Syncline and Træna Basin (Fig. 1) during the rifting episode (Vergara et al., 2001)

\section{Tertiary post-rift development}

The Eocene oceanic drift stage marks the termination of the sediment source area to the northwest and the Norwegian mainland as the remaining source. The Eocene succession is dominantly mud, and the thickness increases westward towards the spreading axis (e.g., Lien, 2005). A Late Neogene uplift of the inner shelf and the adjacent landmass, with erosion by glacial processes, induced the westward progradation of a huge Pliocene-Pleistocene wedge (e.g., Stuevold et al., 1992). 
Sub-basins of the Vøring Basin, such as the Træna Basin, Hel Graben and the Någrind and Vigrid synclines (Fig. 1), became inverted due to post-Eocene compression (Fig. 2B, C). Tectonic inversion of basins with thick sediment successions is a common process affecting previously extended continental margins (e.g., Cooper et al., 1989). Compression and inversion resulted in a shift in depositional axes and new depocentres formed.

Huge domes and elongated arches, which formed after the continental breakup, are characteristic features in the Norwegian Sea (Fig. 1) (Blystad et al., 1995). The uplifts, which are located in the previously thinned continental crust, occur as solitary structures (Fig. 1). Some of the structures are associated with major fault complexes (Fig. 2), and reverse reactivation along some of the faults is evident (e.g., Fles Fault Complex), pointing to an element of compression and shortening. However, there is no consensus about timing of the formation of late uplifts in the Norwegian Sea, and several mechanisms to explain the uplifts have been proposed (Bukovics \& Ziegler, 1985; Stuevold et al., 1992; Blystad et al., 1995; Doré \& Lundin, 1996; Henriksen \& Vorren, 1996; Vågnes et al., 1998; Brekke, 2000; Fejerskov et al., 2000; Mogensen et al., 2000; Pacal \& Gabrielsen, 2001; Lundin \& Doré, 2002; Kjeldstad et al., 2003; Henriksen et al., 2005; Imber et al., 2005).

In a comprehensive study based on uplifts in the Vøring Basin, Gómez \& Vergés (2005) concluded that growth of the structures is best explained by a combination of tectonic compression and sediment loading. The contribution from each of these mechanisms as well as the timing of growth, however, is quite variable between the observed structures. In general, compression has initiated the structures to produce a significant part of the dome amplification from Early Oligocene to Miocene. A later and shorter period of growth (2.6 to $1.0 \mathrm{Ma}$ ) occurred because of differential compaction, related to deposition and loading of Late Pliocene-Early Pleistocene prograding wedges (e.g., Stuevold et al., 1992; Kjeldstad et al., 2003).

Despite their large areal extent and considerable amount of uplift (Figs. 1, 2), the total shortening is very modest. The structure representing the trap for the giant Ormen Lange Field in the Møre Basin is a N-S-oriented dome $50 \mathrm{~km}$ in length (Fig. 1), with Paleocene sandstone as reservoir. The dome has its maximum relief near top-Paleocene and intra-Eocene levels (Möller et al., 2004). The structure is approximately $20 \mathrm{~km}$ wide with an amplitude of $450 \mathrm{~m}$ at these levels. As the average dip of the limbs is about 2.5 degrees, the structure represents a gentle fold and the total shortening is in the order of 0.5 percent.

A NE-SW-elongated uplift with a maximum width of $70 \mathrm{~km}$, northwest of the Lofoten-Vesterålen archipelago (Fig. 1), previously mapped as a Cretaceous high (Blystad et al., 1995), was interpreted by Færseth (2012) as a post-Eocene compressional feature. Due to a general absence of Tertiary sediments, the precise timing of growth cannot be accurately determined. However, in the outer shelf northwest of the Utrøst Ridge, Mokhtari \& Pegrum (1992) identified a dome-shaped uplift where sediments interpreted to be Oligocene-Miocene in age onlapped the flanks of the structure during growth. A regional sub-crop map, covering the outer shelf (Sigmond, 1992), also demonstrates post-Eocene uplift and erosion in this area. These observations support the notion that tectonic compression affected the Lofoten-Vesterålen margin, and further suggest that dome amplification in this area was contemporaneous with tectonically induced growth of domes and arches in the Vøring Basin, with the main growth taking place in the Oligocene-Miocene. 


\section{Conclusions}

Greenland was close to Mid Norway and central-northern Norway after the Caledonian Orogeny. The orogeny climaxed with the Early Devonian continent-continent collision and subduction of the Baltic craton beneath Laurentia. A mountain range several kilometres high evolved and remained a positive topographic element throughout the Late Palaeozoic and Early Mesozoic. Non-marine Carboniferous sediments were deposited onshore East Greenland, but there is no evidence of sedimentation during this period in the study area.

In the Norwegian Sea, three major rifting episodes characterised by large-scale basement-involved faulting and crustal thinning are evident. The rift episodes in the Late Permian-Early Triassic, Middle-Late Jurassic and Campanian-Paleocene, were separated by long (c. 70 million year) periods of overall tectonic quiescence.

Until the climax stage of the Jurassic rift episode, rocks of the Caledonian mountain range might have occupied the area between the Halten Terrace and Liverpool Land at the east coast of Greenland. A huge land mass, exposed for erosion, explains the dominance of coarse clastics on the Halten Terrace and beneath the SE Møre Basin. Middle-Lower Jurassic and Triassic sediments entering into the basin from the west contain conglomerates and pebbly sandstones deposited under fluvial, deltaic and marginal marine conditions, and deltaic clinoforms are recorded along the basin margin on the western Halten Terrace.

The large-scale paleogeography, prior to the climax stage of the Jurassic rifting episode, was dominated by a central basement high, bordered by the basin onshore East Greenland and the basin area offshore Mid Norway. Offshore Mid Norway, Late Permian-Early Triassic extension was evident, and Permo-Triassic sediments reached thicknesses of 4000-6000 m, juxtaposed against basement across large normal faults close to the Norwegian mainland. Time-equivalent sediments are largely absent above basement highs surrounding the basin area.

During deposition of Middle Triassic post-rift sediments, the topography created by Late Permian-Early Triassic extension became levelled and younger sediments were deposited over a relatively flat area, represented by the present Trøndelag Platform and the Halten and Dønna terraces. Due to Jurassic extension, there was a change from this wide basin area to a setting where the Halten and Dønna terraces became separate structural entities, down-faulted and with a complex basin-floor topography.

Coarse-clastic supply from the west was still active during deposition of the Late Bajocian-Bathonian Garn Formation. However, following deposition of this formation and due to erosion and accelerated Late Jurassic rifting, the land mass became insignificant as a source. As the basement high ceased to exist as a source area, leaving the narrow Sklinna Ridge as an easternmost remnant in the footwall of the Klakk Fault Complex, no input of coarse material from the west is encountered. This stage of development is regarded as the first indication of a large and continuous marine basin between Mid Norway and East Greenland after the Caledonian Orogeny.

Structural elements that evolved during the Jurassic rifting episode dominate the basin configuration of the Norwegian Sea, and crustal stretching was at a maximum beneath the Møre and Vøring basins. Tectonic relief with deep-water sub-basins existed at the Jurassic-Cretaceous transition, and the Jurassic structural relief was levelled some 60-65 million years after the rifting had ceased. In distal parts of the Norwegian Sea, the crust was thinned to less than $10 \mathrm{~km}$ over substantial areas, and beneath some of the sub-basins the base Cretaceous may be as deep as 15-17 km and apparently overlie basement. 
Effects of the Campanian-Paleocene rift episode are most apparent in the northwestern part of the Vøring Basin, where rifting was terminated by the crustal separation between Greenland and Eurasia at the Paleocene-Eocene boundary. Large domes and elongated arches formed after the continental breakup, located in the previously thinned continental crust of the Vøring and Møre basins, but also along the narrow Lofoten-Vesterålen margin. Growth of the structures resulted from tectonic compression that initiated the structures and produced a significant part of the dome amplification from Early Oligocene to Miocene. A later and shorter period of growth occurred due to differential compaction related to the deposition and loading of Late Pliocene-Early Pleistocene prograding wedges.

Acknowledgements. For many years, I worked with John Gjelberg who passed away in 2012. He performed the description and interpretation of a huge amount of wireline well-log data and cores from the Norwegian Sea, and his work formed a foundation for our understanding of the sedimentology and depositional environment in the eastern part of the investigated area. During my years in Norsk Hydro and later as consultant, I have worked together with a number of geologists and geophysicists and benefited from a close cooperation with them. Reviewers lan Sharp and Tor Sømme contributed valuable comments and suggestions, which helped to improve this article.

\section{References}

Allison, P.A. \& Wells, M.R. 2006: Circulation in large epicontinental seas: What was different and why? Palaios 21, 513-515. https://doi.org/10.2110/palo.2006.S06.

Andersen, T.B. \& Jamtveit, B. 1990: Uplift of deep crust during orogenic extensional collapse: A model based on field studies in the Sogn-Sunnfjord Region of western Norway. Tectonics 9, 1097-1111. https://doi.org/10.1029/TC009i005p01097.

Badley, M.E., Price, J.D., Rambech Dahl, C. \& Agdestein, T. 1988: The structural evolution of the northern Viking Graben and its bearing upon extensional modes of graben formation. Journal of the Geological Society of London 145, 455-472. https://doi.org/10.1144/gsjgs.145.3.0455.

Bell, R.E., Jackson, C.A.L., Elliott, G.M., Gawthorpe, R.L., Sharp, I.R. \& Michelsen, L. 2014: Insights into the development of major rift-related unconformities from geologically constrained subsidence modelling: Halten Terrace, offshore mid Norway. Basin Research 26, 203-224.

https://doi.org/10.1111/bre.12049.

Bergh, S.G., Eig, K., Kløvjan, O.S., Henningsen, T., Olesen, O. \& Hansen, J.-A. 2007: The LofotenVesterålen continental margin: a multiphase Mesozoic-Palaeogene rifted shelf as shown by offshore-onshore brittle fault-fracture analysis. Norwegian Journal of Geology 87, 29-58.

Berglund, L.T., Augustson, J., Færseth, R., Gjelberg, J., \& Ramberg Moe, H. 1986: The evolution of the Hammerfest Basin. In Spencer, A.M. (ed.): Habitat Hydrocarbons on the Norweqian Continental Shelf, Graham and Trotman London, pp. 319-338.

Bering, D. 1992: The orientation of minor fault plane striae and the associated deviatoric stress tensor as key to the fault geometry in part of the Møre-Trøndelag fault zone, onshore central Norway. 
In Larsen, R.M. et al. (eds.): Structural and Tectonic Modelling and its Application to Petroleum Geology, Special Publications Vol. 1 Amsterdam, Elsevier, pp. 83- 90. https://doi.org/10.1016/B978-0-444-88607-1.50010-3.

Berndt, C., Planke, S., Alvestad, E., Tsikalas, F. \& Rasmussen, T. 2001: Seismic volcanostratigraphy of the Norwegian margin: constraints on tectonomagmatic break-up processes. Journal of the Geological Society of London 158, 413-426. https://doi.org/10.1144/jgs.158.3.413.

Bertram, G.T. \& Milton, N.J. 1989: Reconstructing basin evolution from sedimentary thickness; the importance of palaeobathymetric control, with reference to the North Sea Basin. Basin Research 1, 247257. https://doi.org/10.1111/j.1365-2117.1988.tb00020.x.

Bjørnseth, H.M., Grant, S.M., Hansen, E.K., Hossack, J.R., Roberts, D.G. \& Thompson, M. 1997: Structural evolution of the Møre Basin, during the Late Cretaceous and Paleocene. Journal of the Geological Society of London 154, 559-563. https://doi.org/10.1144/gsjgs.154.3.0559.

Blystad, P. \& Søndenå, E. 2005: Exploration history on the Norwegian Continental Shelf, 1990-2002: expectations and results. In Doré, A.G. \& Vining, B.A. (eds.): Petroleum Geology: North-West Europe and Global Perspectives. Proceedings of the 6th Petroleum Geology Conference, Geological Society, London, 63-68. https://doi.org/10.1144/0060063.

Blystad, P., Brekke, H., Færseth, R.B., Larsen, B.T., Skogseid, J. \& Tørudbakken, B. 1995: Structural elements of the Norwegian continental shelf. Part II: The Norwegian Sea Region. Norwegian Petroleum Directorate Bulletin 8, 45 pp.

Braathen, A., Nordgulen, Ø., Osmundsen, P.-T., Andersen, T.B., Solli, A. \& Roberts, D. 2000: Devonian, orogen-parallel, opposed extension in the central Norwegian Caledonides. Geology 28, 615-618. https://doi.org/10.1130/0091-7613(2000)028<0615:DOPOEI>2.3.CO;2.

Braathen, A., Osmundsen, P.T., Nordgulen, Ø., Roberts, D. \& Meyer, G.B. 2002: Orogen-parallel extension of the Caledonides in northern Central Norway: an overview. Norwegian Journal of Geology $82,225-241$.

Breivik, A.J., Mjelde, R., Raum, T., Faleide, J.I., Murai, Y. \& Flueh, E.R. 2011: Crustal structuring beneath the Trøndelag Platform and adjacent areas of the mid-Norwegian margin, as defined from wide-angle seismic and potential field data. Norwegian Journal of Geology 90, 141-161.

Brekke, H. 2000: The tectonic evolution of the Norwegian Sea Continental margin with emphasis on the Vøring and Møre Basins. In Nøttvedt, A. et al. (eds.). Dynamics of the Norwegian Margin, Geological Society of London, Special Publications 167, pp. 327-378. https://doi.org/10.1144/GSL.SP.2000.167.01.13.

Brekke, H. \& Riis, F. 1987: Tectonic and basin evolution of the Norwegian shelf between $62^{\circ}$ and $72^{\circ} \mathrm{N}$. Norsk Geologisk Tidsskrift 67, 295-321.

Brekke, H. \& Solberg, P.O. 1987: The geology of Atløy, Sunnfjord, western Norway. Norges Geologiske Undersøkelse Bulletin 410, 73-94.

Brekke, H., Dahlgren, S., Nyland, B. \& Magnus, C. 1999: The prospectivity of the Vøring and Møre basins on the Norwegian Sea continental margin. In Fleet, A.J. \& Boldy, S.A. (eds.): Petroleum Geology of Northwest Europe: Proceedings of the 5th Conference, pp. 41-61. https://doi.org/10.1144/0050261. 
Brekke, H., Sjulstad, H.I., Magnus, C. \& Williams, R.W. 2001: Sedimentary environments offshore Norway - an overview. In Martinsen, O.J. \& Dreyer, T. (eds.): Sedimentary Environments Offshore Norway - Palaeozoic to Recent, Norwegian Petroleum Society Special Publication 10, pp. 7-37. https://doi.org/10.1016/S0928-8937(01)80006-0.

Bugge, T., Ringås, J.E., Leith, D.A., Mangerud, G., Weiss, H.M. \& Leith, T.I. 2002: Upper Permian as a new play model on the mid-Norwegian continental shelf: Investigated by shallow stratigraphic drilling. American Association of Petroleum Geologists Bulletin 86, 107-127.

https://doi.org/10.1306/61EEDA4E-173E-11D7-8645000102C1865D.

Bukovics, C. \& Ziegler, P.A. 1985: Tectonic development of the Mid-Norway continental margin. Marine and Petroleum Geology 2, 2-22. https://doi.org/10.1016/0264-8172(85)90045-5.

Bukovics, C., Cartier, E.G., Shaw, N.D. \& Ziegler, P.A. 1984: Structure and development of the midNorway Continental Margin. In Spencer, A.M. (ed.): Petroleum Geology of the North European Margin, Norwegian Petroleum Society, pp. 407-423. https://doi.org/10.1007/978-94-009-5626-1_32.

Bøen, F., Eggen, S. \& Vollset, J. 1984: Structures and basins of the margin from $620 \mathrm{~N}$ to $690 \mathrm{~N}$ and their development. In Spencer, A.M. et al. (eds.) Petroleum Geology of the North European Margin, Graham \& Trotman, London, pp. 271-284. https://doi.org/10.1007/978-94-009-5626-1_18.

Caselli, F. 1987: Oblique-slip tectonics Mid-Norwegian Shelf. In Brooks, J. \& Glennie, K.W. (eds.): Petroleum Geology of North-West Europe, Graham and Trotman, London, pp. 1049-1063.

Christensen, F.G., Piasecki S., Stemmerik L. \& Telnæs N., 1993: Depositional Environment and Organic Geochemistry of the Upper Permian Ravnefjeld Formation Source Rock in East Greenland. American Association of Petroleum Geologists Bulletin, 1519-1537.

Clemmensen, L. 1978: Lacustrine Facies and Stromatolites from the Middle Triassic of East Greenland. Journal of Sedimentary Research 48. https://doi.org/10.1306/212F7603-2B24-11D7-8648000102C1865D.

Clemmensen, L. 1980: Triassic rift sedimentation and palaeogeography of central East Greenland. Bulletin Grønlands Geologiske Undersøkelse 136, 72pp.

Coleman, A.J., Jackson, C.A-L. \& Duffy, O.B. 2017: Balancing sub- and supra-salt strain in salt-influenced rifts: Implications for extension estimates. Journal of Structural Geology 102, 208-225.

https://doi.org/10.1016/j.jsg.2017.08.006.

Cooper, M.A., Williams, G.D., Graciansky, P.C., Murphy, R.W., Needham, T., De Paor, D., Stoneley, R., Todd, S.P., Turner, J.P. \& Ziegler, P.A. 1989: Inversion tectonics - a discussion. In Cooper, M.A. \& Williams, G.D. (eds.): Inversion Tectonics, Geological Society of London, Special Publications Classics 44, pp. 335-347. https://doi.org/10.1144/GSL.SP.1989.044.01.18.

Corfield, S., \& Sharp, I. 2000: Structural style and stratigraphic architecture of fault propagation folding in extensional settings: a seismic example from the Smørbukk area, Halten Terrace, Mid-Norway. Basin Research 12, 329-341. https://doi.org/10.1046/j.1365-2117.2000.00133.x. 
Corfield, S., Sharp, I., Haeger, K-O., Dreyer, T. \& Underhill, J. 2001: An integrated study of the Garn and Melke formations (Middle to Upper Jurassic) of the Smørbukk area, Halten Terrace, mid Norway. In Martinsen, O.J. \& Dreyer, T. (eds.): Sedimentary Environments Offshore Norway - Palaeozoic to Recent, Norwegian Petroleum Society Special Publication 10. https://doi.org/10.1016/S0928-8937(01)80014-X.

Dalland, A. 1975: The Mesozoic rocks of Andøya, Northern Norway. Norges Geologiske Undersøkelse 316, 271-287

Dalland, A. 1979: The sedimentary sequence of Andøya, northern Norway — Depositional and structural history. Proceedings, Norwegian Sea Symposium, Troms $\varnothing, 1979$, Norwegian Petroleum Society NNS/26, pp. 1-31.

Dalland, A. 1981: Mesozoic sedimentary succession at Andøya, northern Norway and relation to structural development of the North Atlantic area. In Kerr, J.W. \& Ferguson, A.J. (eds): Geology of the North Atlantic Borderlands, Canadian Society of Petroleum Geologists, Memoir 7, pp. 563-584.

Dalland, A., Augedahl, H.O., Bomstad, K. \& Ofstad, K. 1988: The post-Triassic succession of the MidNorwegian shelf. In Dalland, A. et al. (eds.): A lithostratigraphic scheme for the Mesozoic and Cenozoic succession offshore Mid-and Northern Norway, Norwegian Petroleum Directorate Bulletin 4, pp. 5-42.

Dam, G. \& Surlyk, F. 1992: Forced regressions in a large wave- and storm-dominated anoxic lake, Rhaetian-Sinemurian Kap Stewart Formation, East Greenland. Geology 20, 749-752. https://doi.org/10.1130/0091-7613(1992)020<0749:FRIALW>2.3.CO;2.

Doglioni, C., Agostino, N.D. \& Mariotti, G. 1998: Normal faulting vs. regional subsidence and sedimentation rate. Marine and Petroleum Geology 15, 737-750. https://doi.org/10.1016/S0264-8172(98)00052-X

Dooley, T., McClay, K., \& Pascoe, R. 2003: 3D analogue models of variable displacement extensional faults: applications to the Revfallet Fault system, offshore mid-Norway. Geological Society of London, Special Publications 212, 151-167. https://doi.org/10.1144/GSL.SP.2003.212.01.10.

Doré, A.G. 1992: Synoptic palaeogeography of the Northeast Atlantic Seaway: late Permian to Cretaceous. In Parnell, J. (ed.): Basins on the Atlantic Seaboard: Petroleum Geology, Sedimentology and Basin Evolution, Geological Society of London, Special Publications 62, pp. 421-446. https://doi.org/10.1144/GSL.SP.1992.062.01.31.

Doré, A.G. \& Lundin, E.R. 1996: Cenozoic compressional structures on the NE Atlantic margin: Nature, origin and potential significance for hydrocarbon exploration. Petroleum Geoscience 2, 299-311. https://doi.org/10.1144/petgeo.2.4.299.

Doré, A.G., Lundin, E.R., Fichler, C. \& Olesen, O. 1997: Patterns of basement structure and reactivation along the NE Atlantic margin. Journal of the Geological Society, London 154, 85-92. https://doi.org/10.1144/gsjgs.154.1.0085.

Doré, A.G., Lundin, E.R., Jensen, L.N., Birkeland, Ø., Eliassen, P.E. \& Fichler, C. 1999: Principal tectonic events in the evolution of the northwest European Atlantic margin. In Fleet, A.J. \& Boldy, S.A. (eds.): Petroleum Geology of Northwest Europe: Proceedings of the 5th Conference, pp. 41-62. https://doi.org/10.1144/0050041. 
Dreyer, T. 1992: Significance of tidal cyclicity for modelling of reservoir heterogeneities in the Lower Jurassic Tilje Formation, mid-Norwegian shelf. Norsk geologisk tidsskrift 72, 159-170.

Ehrenberg, S.N. 1993: Preservation of anomalously high porosity in deeply buried sandstones by graincoating chlorite: Examples from the Norwegian continental shelf. American Association of Petroleum Geologists Bulletin 77, 1260-1286. https://doi.org/10.1306/BDFF8E5C-1718-11D7-8645000102C1865D.

Ehrlich, R., \& Gabrielsen, R.H. 2004: The complexity of a ramp-flat fault and its effect on hanging-wall structuring: An example from the Njord oil field, offshore Mid Norway. Petroleum Geoscience 10, 305317. https://doi.org/10.1144/1354-079303-585.

Eide, E.A., Osmundsen, P.T., Meyer, G.B., Kendrick, M.A. \& Corfu, E. 2002: The Nesna shear zone, north-central Norway: an ${ }^{40} \mathrm{Ar} /{ }^{39} \mathrm{Ar}$ record of Middle Devonian-Early Carboniferous ductile extension and unroofing. Norwegian Journal of Geology 82, 317-339.

Eldholm, O. \& Grue, K. 1994: North Atlantic volcanic margins: dimensions and production rates. Journal of Geophysical Research 99, 2955-2968. https://doi.org/10.1029/93JB02879.

Eldholm, O., Sundvor, E. \& Myhre, A.M. 1979: Continental margin off Lofoten-Vesterålen, Northern Norway. Marine Geophysical Researches 4, 3-35. https://doi.org/10.1007/BF00286144.

Eldholm, O., Thiede, J. \& Taylor, E. 1989: Evolution of the Vøring volcanic margin. In Eldholm, O. et al. (eds.): Proceedings of the Ocean Drilling Program, Scientific Results 104, pp. 1033-1065.

https://doi.org/10.2973/odp.proc.sr.104.191.1989.

Elliott, G.M., Wilson, P., Jackson, C.A L. \& Gawthorpe, R.L. 2012: The linkage between fault throw and footwall scarp erosion patterns: an example from the Bremstein Fault Complex, offshore Mid-Norway. Basin Research 24, 180-197. https://doi.org/10.1111/j.1365-2117.2011.00524.x.

Elliott, G.M., Jackson, A.-L., Gawtorpe, R.L., Wilson, P., Sharp, I. \& Michelsen, L. 2015: Late Syn-rift evolution of the Vingleia Fault Complex, Halten Terrace, offshore Mid-Norway; a test of rift basin tectono-stratigraphic models. Basin Research 29, 465- 487. https://doi.org/10.1111/bre.12158.

Engkilde, M. \& Surlyk, F. 2003: Shallow marine syn-rift sedimentation: Middle Jurassic Pelion Formation, Jameson Land, East Greenland. In Ineson, J.R. \& Surlyk, F. (eds): The Jurassic of Denmark and Greenland, Geological Survey of Denmark and Greenland Bulletin 1, GEUS, pp. 813-863.

https://doi.org/10.34194/geusb.v1.4690.

Faleide, J.I., Tsikalas, F., Breivik, A.J., Mjelde, R., Ritzmann, O., Engen, $\varnothing$., Wilson, J. \& Eldholm, O. 2008: Structure and evolution of the continental margin off Norway and the Barents Sea. Episodes 31, 82-90. https://doi.org/10.18814/epiiugs/2008/v31i1/012.

Fejerskov, M., Lindholm, C.R., Myrvang, A. \& Bungum, H. 2000: Crustal stress in and around Norway: a compilation of in situ stress observations. In Nøttvedt et al. (eds.): Dynamics of the Norwegian Margin, Geological Society of London, Special Publication 167, pp. 441-449.

https://doi.org/10.1144/GSL.SP.2000.167.01.18.

Fjellanger, E., Surlyk, F., Lee, C., Wamsteeker, L.C. \& Midtun, T. 2005: Upper Cretaceous basin-floor fans in the Vøring Basin, Mid Norway Shelf. In Wandås et al. (eds.): Onshore-Offshore Relationships on the North Atlantic Margin, Norwegian Petroleum Society Special Publication 12, pp. 135-164. https://doi.org/10.1016/S0928-8937(05)80047-5. 
Fonneland, H.C., Lien, T., Martinsen, O.J., Pedersen, R.B. \& Kohler, J. 2004: Detrital zircon ages; a key to understanding the deposition of deep marine sandstones in the Norwegian Sea. Sedimentary Geology 164, 147-159. https://doi.org/10.1016/j.sedgeo.2003.09.005.

Forslund, T. 1988: Post-kaledonske forkastninger I Vest-Troms, med vekt på Straumsbukt- Kvaløysletta forkastningen, Kvaløya. Cand. Scient thesis, University of Troms $\varnothing, 169$ pp.

Fossen, H. 1992: The role of extensional tectonics in southern Norway. Journal of Structural Geology 14, 1033-1046. https://doi.org/10.1016/0191-8141(92)90034-T.

Fugelli, E.M.G. \& Olsen, T.R. 2007: Delineating confined slope turbidite systems offshore mid-Norway: The Cretaceous deep-marine Lysing Formation. American Association of Petroleum Geologists Bulletin 91, 1577-1601. https://doi.org/10.1306/07090706137.

Færseth, R.B. 1982: Geology of Southern Stord and adjacent Islands, Southwest Norwegian Caledonides. Norges Geologiske Undersøkelse Bulletin 371, 57-112.

Færseth, R.B. 1996: Interaction between Permo-Triassic and Jurassic extensional fault-blocks during the development of the northern North Sea. Journal of the Geological Society of London 153, 931-944. https://doi.org/10.1144/gsjgs.153.6.0931.

Færseth, R.B. 2012: Structural geology of the continental shelf offshore Lofoten-Vesterålen, northern Norway. Norwegian Journal of Geology 92, 19-40.

Færseth, R.B. \& Lien, T. 2002: Cretaceous evolution of the Norwegian Sea - a period characterized by tectonic quiescence. Marine and Petroleum Geology 19, 1005-1027.

https://doi.org/10.1016/S0264-8172(02)00112-5.

Færseth, R.B. \& Ravnås, R. 1998: Evolution of the Oseberg Fault-Block in context of the northern North Sea structural framework. Marine and Petroleum Geology 15, 467-490.

https://doi.org/10.1016/S0264-8172(97)00046-9.

Færseth, R.B., Thon, A., Larsen, S.G., Sivertsen, A. \& Elvestad, L. 1977: Geology of the Lower Palaeozoic rocks of the Samnanger-Osterøy area, Major Bergen Arc, Western Norway. Norges Geologiske Undersøkelse Bulletin 334, 19-58.

Færseth, R.B., Gabrielsen, R.H. \& Hurich, C.H. 1995a: Influence of basement in structuring of the North Sea basin, offshore southwest Norway. Norsk Geologisk Tidsskrift 75, 105-119.

Færseth, R.B., Sjøblom, T.S., Steel, R.J., Liljedahl, T., Sauar, B.E. \& Tjelland, T. 1995b: Tectonic controls on Bathonian-Volgian syn-rift successions on the Visund fault block, northern North Sea. In Steel et al. (eds.): Sequence Stratigraphy of the North-West European Margin, Norwegian Petroleum Society Special Publication 5, pp. 325-346. https://doi.org/10.1016/S0928-8937(06)80074-3.

Færseth, R.B., Knudsen, B.-E., Liljedahl, T., Midbøe, P.S. \& Søderstrøm, B. 1997: Oblique rifting and sequential faulting in the Jurassic development of the northern North Sea. Journal of Structural Geology 19, 1285-1302. https://doi.org/10.1016/S0191-8141(97)00045-X.

Færseth, R.B., Johnsen, E. \& Sperrevik, S. 2007: Methodology for risking fault seal capacity: Implications of fault zone architecture. American Association of Petroleum Geologists Bulletin 91, 1231-1246. https://doi.org/10.1306/03080706051. 
Gabrielsen, R.H. \& Ramberg, I.B. 1979: Fracture patterns in Norway from landsat imagery: Results and potential use. Proceedings Norwegian Sea Symposium, Tromsø, Norwegian Petroleum Society NSP/1-28.

Gabrielsen, R.H., Færseth, R.B., Hamar, G. \& Rønnevik, H.C. 1984: Nomenclature of main structural features of the Norwegian Continental Shelf north of $62^{\text {nd }}$ parallel. In Spencer A.M. et al. (eds.): Petroleum Geology of the North European Margin, Norwegian Petroleum Society, Graham and Trotman, London, pp. 41-60. https://doi.org/10.1007/978-94-009-5626-1_5.

Gabrielsen, R., H., Færseth, R.B., Jensen, L.N., Kalheim, J.E., \& Riis, F. 1990: Structural elements of the Norwegian continental shelf, Part I: The Barents Sea. Norwegian Petroleum Directorate Bulletin 6, 33pp.

Gabrielsen, R.H., Odinsen, T. \& Grunnaleite, I. 1999: Structuring of the Northern Viking Graben and the Møre Basin: the influence of basement structural grain, and the particular role of the Møre-Trøndelag Fault Complex. Marine and Petroleum Geology 16, 443-465. https://doi.org/10.1016/S0264-8172(99)00006-9.

Gabrielsen, R.H., Kyrkjebø, R., Faleide, J.I., Fjeldskaar, W. \& Kjennerud, T. 2001: The Cretaceous postrift basin configuration of the northern North Sea. In Martinsen, O.J. \& Dreyer, T. (eds.): Sedimentary Environments Offshore Norway - Palaeozoic to Recent, Norwegian Petroleum Society Special Publication 10, pp. 137-154. https://doi.org/10.1144/petgeo.7.2.137.

Gabrielsen, R.H., Braathen, A., Dehls, J. \& Roberts, D. 2002: Tectonic lineaments of Norway. Norsk Geologisk Tidsskrift 82, 153-174.

Gage, M.S. \& Doré, A.G. 1986: A regional geological perspective of the Norwegian offshore exploration provinces. In Spencer, A.M. et al. (eds.): Habitat of Hydrocarbons on the Norwegian Continental Shelf, Norwegian Geological Society, Graham \& Trotman, London, pp. 21-38.

Gernigon, L., Ringenbach, J.-C., Planke, S., Le Gall, B. \& Jonquet-Kolstø, H. 2003: Extension, crustal structure and magmatism at the outer Vøring Basin, Norwegian Margin. Journal of the Geological Society of London 160, 197-2008. https://doi.org/10.1144/0016-764902-055.

Gernigon, L., Ringenbach, J.-C., Planke, S., \& Le Gall, B. 2004: Deep structures and breakup along volcanic rifted margins: Insights from integrated studies along the outer Vøring Basin (Norway). Marine and Petroleum Geology 21, 363-372. https://doi.org/10.1016/j.marpetgeo.2004.01.005.

Gernigon, L., Blischke, A., Nasuti, A., \& Sand, M. 2015: Conjugate rifted margins, sea-floor spreading and microcontinent: Insights from new high-resolution aeromagnetic surveys in the Norway Basin. Tectonics 34, 907- 933. https://doi.org/10.1002/2014TC003717.

Gernigon, L., Franke, D., Geoffroy, L., Schiffer, L., Foulger, G.R. \& Stoker, M. 2020: Crustal fragmentation, magmatism, and the diachronous opening of the Norwegian-Greenland Sea. Earth-Science Reviews 206. https://doi.org/10.1016/j.earscirev.2019.04.011.

Gjelberg, J. \& Steel, R.J. 1983: Middle Carboniferous marine transgression, Bjørnøya, Svalbard: facies sequences from an interplay of sea level changes and tectonics. Geological Journal 18, 1-19. https://doi.org/10.1002/gj.3350180102.

Gjelberg, J., Dreyer, T., Høie, A., Tjelland, T. \& Lilleng, T. 1987: Late Triassic to Mid-Jurassic sandbody development on the Barents and mid-Norwegian shelf. In Brooks, J. \&. Glennie, K.W. (eds.): Petroleum Geology of North West Europe, Graham and Trotman, London, pp. 1105-1130. 
Gjelberg, J.G., Enoksen, T., Kjærnes, P., Mangerud, G., Martinsen, O.J., Roe, E. \& Vågnes, E. 2001: The Maastrichtian and Danian depositional setting along the eastern margin of the Møre Basin (mid-Norwegian Shelf): Implications for the reservoir development of the Ormen Lange Field. In Martinsen, O.J. \& Dreyer, T. (eds.): Sedimentary Environments - Palaeozoic to Recent, Norwegian Petroleum Society Special Publication 10, pp. 421-440.

https://doi.org/10.1016/S0928-8937(01)80025-4

Gómez, M. \& Vergés, J. 2005: Quantifying the contribution of tectonics vs. Differential compaction in the development of domes along the Mid-Norwegian Atlantic margin. Basin Research 17, 289-310. https:// doi.org/10.1111/j.1365-2117.2005.00264.x.

Gómez, M., Vergés, J., Fernández, M., Torne, M., Ayala, C., Wheeler, W. \& Karpuz, R. 2004: Extensional geometry of the Mid Norwegian Margin before Early Tertiary continental breakup. Marine and Petroleum Geology 21, 177-194. https://doi.org/10.1016/j.marpetgeo.2003.11.017.

Gowers, M.B. \& Lunde, G. 1984: Geological history of Trænabanken. In Spencer, A.M. et al. (eds.): Petroleum Geology of the North European Margin, Norwegian Petroleum Society, Graham and Trotman, London, pp. 237-251. https://doi.org/10.1007/978-94-009-5626-1_17.

Graue, K. 1992: Extensional tectonics in the northernmost North Sea; rifting, uplift, erosion and footwall collapse in Late Jurassic to Early Cretaceous. In Spencer, A.M. (ed.) Generation, accumulation and production of Europe's hydrocarbons; II, Special Publications of the European Association of Petroleum Geoscientists 2, pp. 23-34.

Griffin, W.L., Taylor, P.N., Hakkinen, J.W., Heier, K.S., Iden, I.K., Krogh, E.J., Malm, O.A., Olsen, K.I., Ormaasen, D.E. \& Tveten, E. 1978: Archaean and Proterozoic crustal evolution in LofotenVesterålen, North Norway. Journal of Geological Society of London 135, 629-647. https://doi.org/10.1144/gsjgs.135.6.0629.

Grønlie, A. \& Torsvik T.H. 1989: On the origin and age of hydrothermal thorium-enriched carbonate veins and breccias in the Møre-Trøndelag Fault Zone, central Norway. Norsk Geologisk Tidsskrift 69, 1-19.

Gudlaugsson, S.T., Faleide, J.I., Johansen, S.E. \& Breivik, A.J. 1998: Late Palaeozoic structural development of the South-western Barents Sea. Marine and Petroleum Geology 15, 73-102. https://doi.org/10.1016/S0264-8172(97)00048-2

Hamann, N.E., Wittaker, R.C. \& Stemmerik, L. 2005: Geological development of the Northeast Greenland Shelf. In Doré, A.G. \& Vining, B.A. (eds.): Petroleum Geology: North-West Europe and Global Perspectives - Proceedings of the 6th Petroleum Geology Conference, Geological Society London, pp. 887-902. https://doi.org/10.1144/0060887.

Hansen, J.W., Bakke, S. \& Fanavoll, S. 1992: Shallow drilling Nordland VI and VII 1991. Main Report. IKU report 23.

Hansen, J.-A., Bergh, S.G. \& Henningsen, T. 2012: Mesozoic rifting and basin evolution of the Lofoten-Vesterålen Margin, North Norway; time constraints and regional implications. Norwegian Journal of Geology 91, 203-228.

Hartz, E., Eide, E.A., Andresen, E.A., Midbøe, P., Hodges, K.V. \& Kristiansen, S.K. 2002: ${ }^{40}$ Ar $/{ }^{39}$ Ar geochronology and structural analysis. Basin evolution and detrial feedback mechanisms, Hold with Hope region, East Greenland. Norwegian Journal of Geology 82, 341-358. 
Hartz, E., Kristiansen, S.N., Calvert, A., Hodges, K.V. \& Heeremans, M. 2006: Structural, thermal and rheological control of the Late Paleozoic basins in East Greenland. In Scott, R.A. \& Thurson, D.K. (eds.): Proceedings of the Forth International Conference on Artic Margins, pp. 58-76.

Helgesen, J., Magnus, I., Prosser, S., Saigal, G., Aamodt, G., Dolberg, D. \& Busman, S. 2000: Comparison of constrained sparse spike and stochastic inversion for porosity prediction at Kristin Field. Leading Edge 19, 400-407. https://doi.org/10.1190/1.1438620.

Henriksen, S. \& Vorren, T.O. 1996: Late Cenozoic sedimentation and uplift history on the mid-Norwegian continentalshelf. GlobalPlanetaryChange12,171-199. https://doi.org/10.1016/0921-8181(95)00019-4.

Henriksen, S., Fichler, C., Grønlie, A., Henningsen, T., Laursen, I., Løseth, H., Ottesen, D. \& Prince, I. 2005: The Norwegian Sea during the Cenozoic. In Wandås, R. et al. (eds.): Onshore-Offshore Relationships on the North Atlantic Margin, Norwegian Petroleum Society Special Publication 12, pp. 111-133. https://doi.org/10.1016/S0928-8937(05)80046-3.

Henstra, G.H., Gawthorpe, R.L., Helland-Hansen, W., Ravnås, R. \& Rotevatn, A. 2016: Depositional systems in multiphase rifts: Seismic case study from the Lofoten margin, Norway. Basin Research 29, 1-23. https://doi.org/10.1111/bre.12183.

Ichaso, A.A., Dalrymple, R.W. \& Martinius, A.W. 2016: Basin analysis and sequence stratigraphy of the synrift Tilje Formation (Lower Jurassic), Halten terrace giant oil and gas fields, offshore mid-Norway. American Association of Petroleum Geologists Bulletin 100, 1329-1375. https://doi.org/10.1306/02251614081.

Imber, J., Holdsworth, R.E., McCaffrey, K.J.W., Wilson, R.W., Jones, R.R., England, R.W. \& Gjeldvik, G. 2005: Early Tertiary sinistral transpression and fault reactivation in the western Vøring Basin, Norwegian Sea: Implications for hydrocarbon exploration and pre-breakup deformation in ocean margin basins. American Association of Petroleum Geologists Bulletin 89, 1043-1069. https://doi.org/10.1306/02240504043.

Jackson, J.S. \& Hastings, D.S. 1984: The role of salt movements in the tectonic history of the Haltenbanken and Trænabanken and its relationship to structural style. In Spencer, A.M. et al. (eds.): Petroleum Geology of the North European Margin, Norwegian Petroleum Society, pp. 241-257.

Jacobsen, V.W. \& van Veen, P. 1984: The Triassic offshore Norway north of $62^{\circ}$ N. In Spencer, A.M et al. (eds.): Petroleum Geology of the North European Margin, Graham \& Trotman London, pp. 317-327. https://doi.org/10.1007/978-94-009-5626-1_23.

Johannessen, E.P. \& Nøttvedt, A. 2006: Landet omkranset av kystsletter og deltaer; 206-160 Ma. In Ramberg et al. (eds.): Landet blir til, Norsk Geologisk Forening, pp. 354-381.

Jongepier, K., Rui, J.C. \& Grue, K. 1996: Triassic to Early Cretaceous stratigraphy and structural development of the northeastern Møre Basin, off Mid-Norway. Norsk Geologisk Tidsskrift 76, 199-214.

Jørgensen, F. \& Navrestad, T. 1981: The geology of the Norwegian shelf between $620 \mathrm{~N}$ and the Lofoten Islands. In Illing, L.V. \& Hobson, G.D. (eds.): Petroleum geology of the continental shelf of NW Europe, Institute of Petroleum Geologists, London, pp. 407-413. 
Kelly, S.R.A., Whitham, A.G., Koraini, A.M. \& Price, S.R. 1998: Lithostratigraphy of the Cretaceous (Baremian-Santonian) Hold with Hope Group, NE Greenland. Journal of the Geological Society of London 155, 993-1008. https://doi.org/10.1144/gsjgs.155.6.0993.

Kittelsen, J.E., Hollingsworth, R.R., Marten, R.F. \& Hansen, E.K. 1999: The first deep water well in Norway and its implications for the Cretaceous plat, Vøring Basin. In Fleet, A.J. \& Boldy, S.A. (eds.): Petroleum Geology of Northwest Europe: Proceedings of the $5^{\text {th }}$ Conference, Geological Society of London, pp. 275-280. https://doi.org/10.1144/0050275.

Kjeldstad, A., Skogseid, J., Langtangen, H.P., Bjørlykke, K. \& Høeg, K. 2003: Differential loading by prograding sedimentary wedges on continental margins: an arch-forming mechanism. Journal of Geophysical Research 108. https://doi.org/10.1029/2001JB001145.

Kjærefjord, J.M. 1999: Bayfill successions in the Lower Jurassic Åre Formation, Offshore Norway: Sedimentology and heterogeneity based on subsurface data from the Heidrun Field and analog data from the Upper Cretaceous Neslen Formation, eastern Book Cliffs, Utah. In Hentz (ed.): Advanced Reservoir Characterization for the TwentyFirst Century, Society of Economic Paleontologists and Mineralogists, pp. 149-157. https://doi.org/10.5724/gcs.99.14.0149.

Klefstad, L., Kvarsvik, S., Ringås, J.E., Stene, J.J. \& Sundby, O. 2005: Characterization of deeply burried heterolithic tidal reservoirs in the Smørbukk Field using inverted post-stack seismic acoustic impedance. Petroleum Geoscience 11, 47-56. https://doi.org/10.1144/1354-079304-630.

Koppelhus, E.B. \& Dam, G. 2003: Palynostratigraphy and palaeoenvironment of the Middle Jurassic Sortehat Formation (Neill Klinter Group), Jameson Land, East Greenland. Geological Survey of Denmark and Greenland Bulletin (GEUS) 1, 777-811. https://doi.org/10.34194/geusb.v1.4689.

Koppelhus, E.B. \& Hansen, C.F. 2003: Palynostratigraphy and palaeoenvironments of the Rævekløft, Gule Horn and Ostreaelv Formations (Lower-Middle Jurassic), Neill Klinter Group, Jameson Land, East Greenland. Geological Survey of Denmark and Greenland Bulletin 1, 723-775. https://doi.org/10.34194/geusb.v1.4688.

Korte, C., Hesselbo, S.P., Ullmann, C.W., Dietl, G., Ruhl, M., Schweigert, G. \& Thibault, N. 2015: Jurassic climate mode governed by ocean gateway. Nature Communications 6, 1-7. https://doi.org/10.1038/ncomms10015.

Kyrkjebø, R., Gabrielsen, R.H. \& Faleide, J.I. 2004: Unconformities related to the JurassicCretaceous synrift-post-rift transition of the northern North Sea. Journal of the Geological Society 161, 1-17. https://doi.org/10.1144/0016-764903-051.

Larsen, V.B. 1987: A synthesis of tectonically-related stratigraphy in the North AtlanticArctic region from Aalenian to Cenomanian time. Norsk Geologisk Tidsskrift 67, $281-293$.

Larsen, M., Nedkvitne, T. \& Olaussen, S. 2001: Lower Cretaceous (Barremian-Albian) deltaic and shallow marine sandstones in North-East Greenland - sedimentology, sequence stratigraphy and regional implications. In Martinsen, O.J. \& Dreyer, T. (eds.): Sedimentary Environments Offshore Norway Palaeozoic to Recent, Norwegian Petroleum Society Special Publication 10, pp. 259-278. https://doi.org/10.1016/S0928-8937(01)80017-5. 
Larsen, M., Piasecki, S. \& Surlyk, F. 2003. Stratigraphy and sedimentology of a basement-onlapping shallow marine sandstone succession, the Charcot Bugt Formation, Middle-Upper Jurassic, East Greenland. Geological Survey of Denmark and Greenland Bulletin 1, 893-930. https://doi.org/10.34194/geusb.v1.4693.

Leirvik, K.S., Spencer, A.M. \& Warrington, G. 1989: Outline of Triassic stratigraphy and structure in the central and northern North Sea. In Collinson, J.D. (ed.): Correlation in Hydrocarbon Exploration, Norwegian Petroleum Society, Graham \& Trotman, London, pp. 173-190.

https://doi.org/10.1007/978-94-009-1149-9_14.

Lien, T. 2005: From rifting to drifting: effects on the development of deep-water hydrocarbon reservoirs in a passive margin setting, Norwegian Sea. Norwegian Journal of Geology 85, 319-332.

Lundin, E.R. \& Doré, A.G. 1997: A tectonic model for the Norwegian passive margin with implications for the NE Atlantic: Early Cretaceous to break-up. Journal of the Geological Society of London 154, 545-550. https://doi.org/10.1144/gsjgs.154.3.0545.

Lundin, E.R. \& Doré, A.G. 2002: Mid-Cenozoic post-breakup deformation in the "passive" margins bordering the Norwegian-Greenland Sea. Marine and Petroleum Geology 19, 79-93.

https://doi.org/10.1016/S0264-8172(01)00046-0.

Lundin, E.R. \& Doré, A.G. 2011: Hyperextension, serpentinization, and weakening: A new paradigm for rifted margin compressional deformation. Geology 39, 347-350. https://doi.org/10.1130/G31499.1.

Løseth, H., \& Tveten, E. 1996: Post-Caledonian structural evolution of the Lofoten and Vesterålen offshore and onshore areas. Norwegian Journal of Geology 76, 215-230.

Manatschal, G. 2004: New models for evolution of magma-poor rifted margins based on a review of data and concepts from West Iberia and the Alps. International Journal of Earth Sciences 93, 432- 466. https://doi.org/10.1007/s00531-004-0394-7.

Marsh, N.. Imber, J., Holdsworth, R.E., Brochbank, P. \& Ringrose, P. 2010: The structural evolution of the Halten Terrace, offshore Mid-Norway: extensional fault growth and strain localization in a multi-layer brittle-ductile system. Basin Research 22, 1995-2014.

https://doi.org/10.1111/j.1365-2117.2009.00404.x.

Martinius, A., Kaas, I., Næss, A., Helgesen, G., Kjærefjord, J. \& Leith, D.A . 2001: Sedimentology of the heterolithic and tide-dominated Tilje Formation (Early Jurassic, Halten Terrace, offshore mid-Norway). In Martinsen, O. \& Dreyer, T. (eds): Sedimentary Environments Offshore Norway, Norwegian Petroleum Society, Special Publication 10, Elsevier. https://doi.org/10.1016/S0928-8937(01)80011-4.

Martinius, A.W., Ringrose, P.S., Brostrøm, C., Elfenbein, C., Næss, A. \& Ringås, J.E. 2005: Reservoir challenges of heterolithic tidal sandstone reservoirs in the Halten Terrace, mid-Norway. Petroleum Geoscience 11, 3-16. https://doi.org/10.1144/1354-079304-629.

Martinsen, O.J., Bøen, F., Charnock, M.A., Mangerud, G. \& Nøttvedt, A. 1999: Cenozoic development of the Norwegian margin 60-64oN: sequences and sedimentary response to variable basin physiography and tectonic setting. In Fleet, A.J. \& Boldy, S.A.R. (eds.): Petroleum Geology of Northwest Europe: Proceedings of the 5th Conference, Geological Society of London, pp. 293-304. https://doi.org/10.1144/0050293. 
Martinsen, O.J., Lien, T. \& Jackson, C. 2005: Cretaceous and Paleogene turbidite systems in the North Sea and Norwegian Sea basins: source, staging area and basin physiography controls on reservoir development. In Doré, A.G. \& Vining, B.A. (eds.): Petroleum Geology: Northwest Europe and Global Perspectives - Proceedings of the 6th Petroleum Geology Conference, Geological Society of London, pp. 1147-1164. https://doi.org/10.1144/0061147.

Messina, C., Nemec, W., Martinius, A.W. \& Elfenbein, C. 2014: The Garn Formation (BajocianBathonian) in the Kristin Field, Halten Terrace: its origin, facies architecture and Primary heterogeneity model. International Association of Sedimentologists Special Publication 46, 513-550.

https://doi.org/10.1002/9781118920435.ch18.

Mjelde, R., Sellevoll, M.A., Shimamura, H., Iwasaki, T. \& Kanazawa, T. 1993: Crustal structure beneath Lofoten, N. Norway from vertical incidence and wide-angle seismic data. Geophysical Journal International 114, 116-126. https://doi.org/10.1111/j.1365-246X.1993.tb01471.x.

Mjelde, R., Kodaira, S., \& Sellevoll, M.A. 1996: Crustal structure of the Lofoten margin, N. Norway, from normal incidence and wide-angle seismic data: A review. Norges Geologiske Tidsskrift 76, 187-198.

Mjelde, R., Kodaira, S., Shimamura, H., Kanazawa, T., Shiobara, H., Berg, E.W. \& Riise, O. 1997: Crustal structure of the central part of the Vøring Basin, mid-Norway margin, from ocean-bottom seismographs. Tectonophysics 277, 235-257. https://doi.org/10.1016/S0040-1951(97)00028-0.

Mjelde, R., Digranes, P., Shimamura, H., Shiobara, H., Kodaira, S., Brekke, H., Egebjerg, T., Sørensen, N. \& Thorbjørnsen, S. 1998: Crustal structure of the northern part of the Vøring Basin, mid-Norway margin, from wide-angle seismic and gravity data. Tectonophysics 293, 175-205. https://doi.org/10.1016/S0040-1951(98)00090-0.

Mjelde, R., Planke, S., Digranes, P., Van Schaak, M., Shimamura, H., Shiobara, H., Kodeira, S., Næss, O., Sørensen, N. \& Vågenes, E. 2001: Crustal structures of the outer Vøring Plateau, offshore Norway, from ocean bottom seismic and gravity data. Journal of Geophysical Research 106. https://doi.org/10.1029/2000JB900415.

Mjelde, R., Raum, T., Breivik, A., Shimamura, H., Murai, Y., Takanami, T. \& Faleide, J.I. 2005: Crustal structure of the Vøring Margin, NE Atlantic: a review of geological implications based on recent OBS data. In Doré, A.G. \& Vining, B.A. (eds.): Petroleum Geology: North-West Europe and Global Perspectives - Proceedings of the 6th Petroleum Geology Conference, Geological Society, London, pp. 803-814. https://doi.org/10.1144/0060803.

Mjelde, R., Raum, T., Murai, Y. \& Takanami, T. 2007: Continent-ocean transition: Review, and tectono-Magmatic model of the Vøring Plateau, NE Atlantic. Journal of Geodynamics 43, 374-392. https://doi.org/10.1016/j.jog.2006.09.013.

Mjelde, R., Faleide, J.I., Breivik, A.J., \& Raum, T. 2009: Lower crustal composition and crustal lineaments on the Vøring Margin, NE Atlantic: A review. Tectonophysics 472, 183-193.

https://doi.org/10.1016/j.tecto.2008.04.018.

Mogensen, T.E., Nyby, R., Karpuz, R. \& Haremo, P. 2000: Late Cretaceous and Tertiary structural evolution of the northeastern part of the Vøring Basin, Norwegian Sea. In Nøttvedt et al. (eds.): Dynamics of the Norwegian Margin, Geological Society of London, Special Publication 167, pp. 379-396. 
https://doi.org/10.1144/GSL.SP.2000.167.01.14.

Mokhtari, M. \& Pegrum, R.M. 1992: Structure and evolution of the Lofoten continental margin, offshore Norway. Norsk Geologisk Tidsskrift 72, 339-355.

Morisbak Jarsve, E., Faleide, J.I. \& Gabrielsen, R.H. 2014: Mesozoic and Cenozoic configuration in the North Sea. International Association of Sedimentologists Special Publication 46, 417-452. https://doi.org/10.1002/9781118920435.ch15.

Morton, A.C. \& Chenery, S. 2009: Detrital rutile geochemistry and thermometry as guides to provenance of Jurassic-Paleocene sandstones of the Norwegian Sea. Journal of Sedimentary Research 79, 540553. https://doi.org/10.2110/jsr.2009.054.

Morton, A.C., Whitham, A.G. \& Fanning, C.M. 2005: Provenance of Late Cretaceous to Paleocene submarine fan sandstones in the Norwegian Sea: Integration of heavy mineral, mineral chemical and zircon age data. Sedimentary Geology 182, 3-28. https://doi.org/10.1016/j.sedgeo.2005.08.007.

Morton, A.C., Hallsworth, C., Strogen, D., Whitham, A. \& Fanning, M. 2009: Evolution of provenance in the NE Atlantic rift: The Early-Middle Jurassic succession in the Heidrun Field, Halten Terrace, offshore Mid-Norway. Marine and Petroleum Geology 26, 1100-1117. https://doi.org/10.1016/j.marpetgeo.2008.07.006.

Mosar, J. 2003: Scandinavia's North Atlantic passive margin. Journal of Geophysical Research 108, 1-18. https://doi.org/10.1029/2002JB002134

Mosar, J., Eide, E.A., Osmundsen, P.T., Sommaruga, A. \& Torsvik, T.H. 2002: Greenland - Norway separation: A geodynamic model for the North Atlantic. Norwegian Journal of Geology 82, 281-298.

Müller, R., Nystuen, J.P., Eide, F. \& Lie, H. 2005: Late Permian to Triassic basin infill history and palaeogeography of the Mid-Norwegian shelf - East Greenland region. In Wandås, R. et al. (eds.): Onshore-Offshore Relationships on the North Atlantic Margin, Norwegian Petroleum Society Special Publication 12, pp. 165-189. https://doi.org/10.1016/S0928-8937(05)80048-7.

Möller, N.K, Gjelberg, J.F., Martinsen, O., Charnock, M.A., Færseth, R.B., Sperrevik, S. \& Cartwright, J.A. 2004: A geological model for the Ormen Lange hydrocarbon reservoir. Norwegian Journal of Geology 84, 169-190.

Mørk, M.B.E., Os Vigran, J., Smelror, M., Fjerdingstad, V. \& Bøe, R. 2003: Mesozoic mudstone composition and the role of kaolinite weathering - a view from shallow cores in the Norwegian Sea. Norwegian Journal of Geology 83, 61-78.

Nelson, P.H.H. \& Lamy, J.-M. 1987: The Møre/West Shetland Area: a review. In Brooks, J. \& Glennie, K.W. (eds.): Petroleum Geology of North-West Europe, Graham and Trotman, London, pp. 775-784.

Nirrengarten, M., Gernigon, L. \& Manatschal, G. 2014: Lower crustal bodies in the Møre volcanic rifted margin: Geophysical determination and geological implications. Tectonophysics 636, 143-157. https://doi.org/10.1016/j.tecto.2014.08.004.

Norton, M.G. 1986: Late Caledonian extension in western Norway: a response to extreme crustal thickening. Tectonics 5, 195-2004. https://doi.org/10.1029/TC005i004p00707.

Nystuen, J.P., Müller, R., Mørk, A. \& Nøttvedt, A. 2006: Fra ørken til elveslette. Trias; 251-200 Ma. In Ramberg et al. (eds.): Landet blir til. Norsk Geologisk Forening, pp. 328-353. 
Nøttvedt, A. \& Worsley, D. 2006: Karbon og perm i nord (359-251 Ma). In Ramberg et al. (eds.): Landet blir til, Norsk Geologisk Forening, pp. 258-283.

Nøttvedt, A., Gabrielsen, R.H., \& Steel, R.J. 1995: Tectono-stratigraphy and sedimentary architecture of rift basins, with reference to the northern North Sea. Marine and Petroleum Geology 8, 881-901. https://doi.org/10.1016/0264-8172(95)98853-W.

Nøttvedt, A., Johannesen, E.P. \& Surlyk, F. 2008: The Mesozoic of Western Scandinavia and East Greenland. Episodes 31, 1-7. https://doi.org/10.18814/epiiugs/2008/v31i1/009.

Oftedal, B.T., Andresen, A. \& Müller, R. 2005: Early Triassic syn-rift sedimentation at Hold with Hope, Northeast Greenland. In Wandås, B.E. et al. (eds): Onshore-Offshore Relationships on the North Atlantic Margin, Norwegian Petroleum Society, Special Publication 12, Elsevier. https://doi.org/10.1016/S0928-8937(05)80049-9.

Olesen, O., Torsvik, T., Tveten, E., Zwaan, K.B., Løseth, H. \& Henningsen, T. 1997: Basement structure of the continental margin in the Lofoten-Lopphavet area, northern Norway: constraints from potential field data, on-land structural mapping and paleomagnetic data. Norwegian Journal of Geology $77,15-30$

Olesen, O., Lundin, E., Nordgulen, Ø., Osmundsen, P.T., Skilbrei, J.R., Smethurst, M.A., Solli, A., Bugge \& Fichler, C. 2002: Bridging the gap between the onshore and offshore geology in Nordland, northern Norway. Norwegian Journal of Geology 82, 243-262.

Olesen, O., Brönner, M., Ebbing, J., Gellein, J., Genrigon, L. \& Koziel, J. 2010: New aeromagnetic and gravity compilations from Norway and adjacent areas: Methods and applications. Geological Society of London, Petroleum Geology Conference Series 7, 559- 586. https://doi.org/10.1144/0070559.

Olsen, E., Gabrielsen, R.H., Braathen, A. \& Redfield, T.F. 2007: Fault systems marginal to the Møre-Trøndelag Fault Complex, Osen-Vikna area, Central Norway. Norwegian Journal of Geology 87, 59-73.

Osmundsen, P.T. \& Andersen, T.B. 2001: The middle Devonian basins of western Norway: sedimentary response to large-scale transtensional tectonics? Tectonophysics 332, 51-68. https://doi.org/10.1016/S0040-1951(00)00249-3.

Osmundsen, P.T., \& Ebbing, J. 2008: Styles of extension offshore mid-Norway and implications for mechanisms of crustal thinning at passive margins. Tectonics 27, 1-25.

https://doi.org/10.1029/2007TC002242.

Osmundsen, P.T. \& Péron-Pividic, G. 2018: Crustal-scale fault interaction at rifted margins and the formation of domain-bounding breakaway complexes: Insights from offshore Norway. Tectonics 37, 935-964. https://doi.org/10.1002/2017TC004792.

Osmundsen, P.T., Sommaruga, A., Skilbrei, J.R. \& Olesen, O. 2002: Deep structure of the Mid Norway rifted margin. Norwegian Journal of Geology 82, 205-224.

Osmundsen, P.T., Braathen, A., Nordgulen, $\varnothing .$, Roberts, D., Meyer, G.B. \& Eide, E. 2003: The Nesna shear zone and adjacent gneisscored culminations, North-central Norwegian Caledonides. Journal of the Geological Society 160, 1-14. https://doi.org/10.1144/0016-764901-173. 
Osmundsen, P.T., Braathen, A., Sommaruga, A., Skilbrei, J.R., Nordgulen, Ø. \& Roberts, D. 2005: Metamorphic core complexes and gneiss-cored culminations along the mid-Norwegian margin: An overview and some current ideas. In Wandås, B., Eide, E.A., \& Gradstein, F. (eds.): Onshore-Offshore Relationships on the Mid-Norwegian Margin, Norwegian Petroleum Society, Special Publications 12, pp. 29-31. https://doi.org/10.1016/S0928-8937(05)80042-6.

Osmundsen, P.T., Péron-Pinvidic, G., Ebbing, J., Erratt, D., Fjellanger, E., Bergslien, D. \& Syvertsen, S.E. 2016: Extension, hyperextension and mantle exhumation offshore Norway: a discussion based on 6 crustal transects. Norwegian Journal of Geology 96, 343-372. https://doi.org/10.17850/njg96-4-05.

Pacal, C. \& Gabrielsen, R.H. 2001: Numerical modelling of Cenozoic stress patterns in the mid-Norwegian margin and the northern North Sea. Tectonics 20, 585-599. https://doi.org/10.1029/2001TC900007.

Parsons, A.J., Whitham, A.G., Kelly, S.R.A., Vautravers, B.P.H., Dalton, T.J.S., Andrews, S.D., Pickles, C.S., Strogen, D.P. \& Braham, W. 2017: Structural evolution and basin architecture of the Trail $\varnothing$ region, NE Greenland: A record of polyphaser rifting of East Greenland. Geological Society of America, 733-770. https://doi.org/10.1130/GES01382.1.

Pascoe, R, Hooper, R., Storhaug, K. \& Harper, H. 1999: Evolution of extensional styles to the southern termination of the Nordland Ridge, Mid-Norway: a response to variations in coupling above salt. In Fleet, A.J. \& Boldy, S.A. (eds.): Petroleum Geology of Northwest Europe: Proceedings of the 5th Conference, pp. 83-90. https://doi.org/10.1144/0050083.

Péron-Pinvidic, G. \& Osmundsen, P.T. 2016: Architecture of the distal and outer domains of the mid-Norwegian rifted margin: Insights from the Rån-Gjallar Ridges system. Marine and Petroleum Geology 77, 280- 299. https://doi.org/10.1016/j.marpetgeo.2016.06.014.

Péron-Pinvidic, G. \& Osmundsen, P.T. 2018: The Mid Norwegian-NE Greenland conjugate margins: Rifting evaluation, margin segmentation, and breakup. Marine and Petroleum Geology 98, 162-184. https://doi.org/10.1016/j.marpetgeo.2018.08.011.

Péron-Pinvidic, G., Gernigon, L., Gaina, C. \& Ball, P. 2012: Insights from the Jan Mayen system in the Norwegian-Greenland Sea - II. Architecture of a microcontinent. Geophysical Journal International 191, 413-435. https://doi.org/10.1111/j.1365-246X.2012.05623.x.

Péron-Pinvidic, G., Manatschal, G., \& Osmundsen, P.T. 2013: Structural comparison of archetypal Atlantic rifted margins: A review of observations and concepts. Marine and Petroleum Geology 43, 21-47. https://doi.org/10.1016/j.marpetgeo.2013.02.002.

Price, I. \& Rattey, R.P. 1984: Cretaceous tectonics off mid-Norway: implications for the Rockall Trough and Faeroe-Shetland troughs. Journal of the Geological Society of London 141, 985-992. https://doi.org/10.1144/gsjgs.141.6.0985.

Prosser, S. 1993: Rift-related linked depositional systems and their seismic expression. In Williams, G.D. \& Dobb, A. (eds.): Tectonics and Seismic Stratigraphy, Geological Society, Special Publications 71, pp. 35-66. https://doi.org/10.1144/GSL.SP.1993.071.01.03.

Quin, J.G., Zweigel, P., Eldholm, E., Hansen, O.R., Christoffersen, K.R. \& Zaostrovski, A. 2010: Sedimentology and unexpected pressure decline: the HP/HT Kristin Field. In Vinning, B.A. \& Pickering, S.C. (eds.): Petroleum Geology: From Mature Basins to New Frontiers, Petroleum Geology Conference Series 7, Geological Society, London, pp. 419-429. https://doi.org/10.1144/0070419. 
Rattey, R.P. \& Hayward, A.B. 1993: Sequence stratigraphy of a failed rift system: the Middle Jurassic to Early Cretaceous basin evolution of the Central and Northern North Sea. In Parker, J.R. (ed.): Petroleum Geology of Northwest Europe: Proceedings of the 4th Conference, Geological Society, London, pp. 215-249. https://doi.org/10.1144/0040215.

Raum, T., Mjelde, R., Digranes, P., Shimamura, H., Shiobara, H., Kodaira, S., Haatvedt, G., Sørensen, N. \& Thorbjørnsen, T. 2002: Crustal structure of the southern part of the Vøring Basin, mid-Norway margin, from wide-angle seismic and gravity data. Tectonophysics 355, 99-126.

https://doi.org/10.1016/S0040-1951(02)00136-1.

Ravnås, R. \& Steel, R.J. 1998: Architecture of marine rift-basin successions. American Association of Petroleum Geologists Bulletin 82, 110-146.

Ravnås, R., Nøttvedt, A., Steel, R.J. \& Windelstad, J. 2000: Syn-rift sedimentary architectures in the Northern North Sea. In Nøttvedt. A. (ed.): Dynamics of the Norwegian Margin, Geological Society, London, Special Publications 167, pp. 133-177. https://doi.org/10.1144/GSL.SP.2000.167.01.07.

Ravnås, R., Berge, K., Campbell, H., Harvey, C. \& Norton, M.J. 2014: Halten Terrace Lower and Middle Jurassic inter-rift magasequence analysis: megasequence structure, sedimentary architecture and controlling parameters. International Association of Sedimentologists Special Publication 46, $215-252$. https://doi.org/10.1002/9781118920435.ch10.

Redfield, T.F. \& Osmundsen, P.T. 2013: The long-term topographic response of a continent to a hyperextended margin: A case study from Scandinavia. Geological Society of America Bulletin 125, 184- 200. https://doi.org/10.1130/B30691.1.

Redfield, T.F., Osmundsen, P.T. \& Hendriks, B.W.H. 2005: The role of fault reactivation and growth in the uplift of western Norway. Journal of the Geological Society of London 162, 1013-1030. https://doi.org/10.1144/0016-764904-149.

Reemst, P. \& Cloetingh, S. 2000: Polyphase rift evaluation of the Vøring margin (mid Norway): Constraints from forward tectonostratigraphic modelling. Tectonics 19, 225-240.

https://doi.org/10.1029/1999TC900025.

Ren, S., Skogseid, J. \& Eldholm, O. 1998: Late Cretaceous-Paleocene extension on the Vøring Volcanic margin. Marine Geophysical Researches 20, 343-369. https://doi.org/10.1023/A:1004554217069.

Ren, S., Faleide, J.I., Eldholm, O., Skogseid, J. \& Gradstein, F. 2003: Late Cretaceous - Paleocene tectonic development of the NW Vøring Basin. Marine and Petroleum Geology 20, 177-206. https://doi.org/10.1016/S0264-8172(03)00005-9.

Richardson, N.J., Underhill, J. R. \& Lewis, G. 2005: The role of evaporite mobility in modifying subsidence patterns during normal fault growth and linkage, Halten Terrace, Mid-Norway. Basin Research 17, 203-223. https://doi.org/10.1111/j.1365-2117.2005.00250.x.

Roberts, D. \& Gee, D.G. 1985: An introduction to the structure of the Scandinavian Caledonides. In Gee, D.G. \& Sturt, B.A. (eds.): The Caledonide Orogen - Scandinavia and Related Areas, Chichester, John Wiley and Sons, pp. 55-68. https://doi.org/10.1144/0050007. 
Roberts, A.M. \& Yielding, G. 1991: Deformation around basin-margin faults in the North Sea/midNorway rift. In Roberts, A.M., Yielding, G. \& Freeman, B. (eds.): The Geometry of Normal Faults, Geological Society Special Publication 56, pp. 61-78. https://doi.org/10.1144/GSL.SP.1991.056.01.05.

Roberts, D.G., Thompson, M., Mitchener, B., Hossack, J., Carmichael, S. \& Bjørnseth, H.-M. 1999: Palaeozoic to Tertiary rift and basin dynamics: mid-Norway to the Bay of Biscay - a new context for hydrocarbon prospectivity in deep water frontier. In Fleet, A.J. \& Boldy, S.A. (eds.): Petroleum Geology of Northwest Europe: Proceedings of the $5^{\text {th }}$ Conference, pp. 7-40. https://doi.org/10.1144/0050007.

Rosendahl, B.R. 1987: Architecture of continental rifts with special reference to East Africa. Annual Reviews Earth Planetary Sciences 15, 445-503. https://doi.org/10.1146/annurev.ea.15.050187.002305.

Rotevatn, A., Kristensen, T.B., Ksienzyk, A.K., Wemmer, K., Henstra, G.A., Midtkandal, I., Grundvåg, S.-A. \& Andresen, A. 2018: Structural inheritance and rapid rift-length establishment in multiphase rift: The East Greenland rift system and its Caledonian orogenic ancestry. Tectonics 37, 1858-1875. https://doi.org/10.1029/2018TC005018.

Rønnevik, H.C. \& Navrestad, H. 1976. Geology of the Norwegian Shelf between $62^{\circ} \mathrm{N}$ and $69^{\circ} \mathrm{N}$. Exploration Geology and Geophysics Offshore North Sea Conference, Norwegian Petroleum Society, Stavanger, 1976, G-IV/4, pp. 1-24.

Rønnevik, H.C. \& Navrestad, H. 1977. Geology of the shelf between $62^{\circ} \mathrm{N}$ and $69^{\circ}$ N. GeoJournal 1, 33-46. https://doi.org/10.1007/BF00189602.

Schmidt, W.J. 1992: Structure of the Mid-Norway Heidrun Field and its regional implications. In Larsen, R.M., Brekke, H., Larsen, B.T. \& Tallerås, E. (eds.): Norwegian Petroleum Society Special Publication 1. https://doi.org/10.1016/B978-0-444-88607-1.50031-0.

Seidler, L., Steel, R.J., Stemmerik, L. \& Surlyk, F. 2004: North Atlantic marine rifting in the Early Triassic: new evidence from East Greenland. Journal of the Geological Society of London 161, 583-592. https://doi.org/10.1144/0016-764903-063.

Sigmond, E. 1992: Bedrock map of Norway and adjacent ocean areas, scale 1:3 million, Geological Survey of Norway.

Skilbrei, J.R., \& Olesen, O. 2005: Deep structure of the mid-Norwegian shelf and onshore-offshore correlations: Insight from potential field data. Norwegian Petroleum Society, Special Publications 12, 43-68. https://doi.org/10.1016/S0928-8937(05)80043-8.

Skilbrei, J.R., Olesen, O., Osmundsen, P.T., Kihle, O., Aaro, S. \& Fjellanger, E. 2002: A study of basement structures and onshore-offshore correlations in Central Norway. Norwegian Journal of Geology 82, 263-279.

Skogseid, J. \& Eldholm, O. 1989: Vøring Continental Margin: Seismic interpretation, stratigraphy and vertical movements. In Eldholm, O., Thiede, J. \& Taylor, E. (eds.): Proceedings of the Ocean Drilling Program, Scientific Results 104, College Station, Texas, pp. 993-1030.

https://doi.org/10.2973/odp.proc.sr.104.151.1989. 
Skogseid, J., Pedersen, T., Eldholm, O. \& Larsen, B.T. 1992: Tectonism and magmatism during NE Atlantic continental break-up: the Vøring margin. In Storey, B.C., Alabaster, T. \& Pankhurst, R.J. (eds.): Magmatism and the causes of continental break-up, Geological Society of London Special Publications 68, pp. 305-320. https://doi.org/10.1144/GSL.SP.1992.068.01.19.

Skogseid, J., Planke, S., Faleide, J.I., Pedersen, T., Eldholm, O. \& Neverdal, F. 2000: NE Atlantic continental rifting and volcanic margin formation. In $\mathrm{N} \varnothing \mathrm{ttvedt}, \mathrm{A}$. et al. (eds.): Dynamics of the Norwegian Margin, Geological Society of London Special Publication 167, pp. 295-326.

https://doi.org/10.1144/GSL.SP.2000.167.01.12.

Slagstad, T., Davidsen, B. \& Daly, J.S. 2011: Age and composition of crystalline basement rocks on the Norwegian continental margin: offshore extension and continuity of Caledonian - Appalachian orogenic belt. Journal of the Geological Society of London 168, 1167-1185. https://doi.org/10.1144/0016-76492010-136

Smelror, M., Jacobsen, T., Rise, L., Skarbø, O., Verdenius, J. \& Vigran, J. 1994: Jurassic to Cretaceous stratigraphy of shallow cores on the Møre Basin Margin, Mid-Norway. Norsk Geologisk Tidsskrift 74, 89-107.

Smelror, M., Mørk, A., Mørk, M.B.E., Weiss, H.M. \& Løseth, H. 2001: Middle Jurassic-Lower Cretaceous transgressive-regressive sequences and facies distribution off Northern Nordland and Troms, Norway. In Martinsen, O.J. \& Dreyer, T. (eds): Sedimentary environments offshore Norway Palaeozoic to recent, Norwegian Petroleum Society Special Publication 10, pp. 211-232. https://doi.org/10.1016/S0928-8937(01)80015-1.

Steel, R.J. 1993: Triassic-Jurassic megasequence stratigraphy in the Northern North Sea. In Parker, J.R. (ed.): Petroleum Geology of Northwest Europe: Proceedings of the 4th Conference. Geological Society, London, pp. 299-315. https://doi.org/10.1144/0040299.

Steel, R.J. \& Gloppen, T.G. 1980: Late Caledonian (Devonian) basin formation, western Norway: Signs of strike-slip tectonics during infilling. Special Publication of the International Association of Sedimentologists 4, 79-103. https://doi.org/10.1002/9781444303735.ch6.

Steel, R.J. \& Ryseth, A. 1990: The Triassic-early Jurassic succession in the northern North Sea: megasequence stratigraphy and intra-Triassic tectonics. In Hardman, R.P.F. \& Brooks, J. (eds): Tectonic events responsible for Britain's Oil and Gas reserves, Geological Society of London, Special Publications 55, pp. 139-168. https://doi.org/10.1144/GSL.SP.1990.055.01.07.

Steel, R.J. \& Worsley, D. 1984: Svalbard's post-Caledonian strata - an atlas of sedimentological patterns and palaeogeographic evolution. In Spencer, A.M. (ed.): Petroleum Geology of the North European Margin, Norwegian Petroleum Society, Graham \& Trotman pp. 109-135. https://doi.org/10.1007/978-94-009-5626-1_9.

Steel, R.J., Sidlecka, A. \& Roberts, D. 1985: The Old Red Sandstone basins of Norway and their deformation: an overview. In Gee, D.G. \& Sturt, B.A. (eds.): The Caledonian Orogen - Scandinavia and related areas, Chichester, Wiley \& Sons Ltd., pp. 293-315.

Steltenpohl, M.G., Hames, W.E. \& Andresen, A. 2004: The Silurian to Permian history of a metamorphic core complex in Lofoten, northern Scandinavian Caledonides. Tectonics 23, 1-23.

https://doi.org/10.1029/2003TC001522. 
Stemmerik, L. 1995: Permian history of the Norwegian-Greenland Sea area. In Scholle, P.A., Peryt, T.M. \& Ulmer-Scholle, D.J. (eds.): The Permian of Northern Pangea 2. Sedimentary Basins and Economic Resources, Springer, Berlin, pp. 98-118. https://doi.org/10.1007/978-3-642-78590-0_6.

Stemmerik, L. 2000: Late Palaeozoic evolution of the North Atlantic margin of Pangea. Palaeogeography, Palaeoclimatology, Palaeooecology 161, 95-126. https://doi.org/10.1016/S0031-0182(00)00119-X.

Stemmerik, L., Scholle, P.A., Henk, F.H., Di Liegro, G. \& Ulmer, D.S. 1993: Sedimentology and diagenesis of the Upper Permian Wegener Halv $\varnothing$ Formation carbonates along the margins of the Jameson Land Basin, East Greenland. In Vorren, T.O., Bergsager, E., Dahl-Stammes, Ø.A., Holter, E., Johansen, B., Lie, E. \& Lund, T.B. (eds): Arctic Geology and Petroleum Potential, Norwegian Petroleum Society Special Publication 2, Amsterdam, Elsevier, pp. 107-119. https://doi.org/10.1016/B978-0-444-88943-0.50012-5.

Stemmerik, L., Clausen, O.R., Korstgård, J., Larsen, M., Piasecki, S., Seidler, L., Surlyk, F. \& Therkelsen, J. 1997: Petroleum geological investigations in East Greenland: project 'Resources of the sedimentary basis of North and East Greenland'. Geology of Greenland Survey Bulletin 176, 29-38. https://doi.org/10.34194/ggub.v176.5058.

Stemmerik, L., Larsen, B.D. \& Dalhoff, E. 2000: Tectono-stratigraphic history of northern Amdrup Land, eastern North Greenland. Geology of Greenland Survey Bulletin 187, 7-19.

https://doi.org/10.34194/ggub.v187.5192.

Stemmerik, L., Bendix-Almgreen, S.E. \& Piasecki, S. 2001: The Permian-Triassic boundary in central East Greenland: past and present views. Bulletin Geological Society of Denmark 48, 159-167.

Storvoll, V., Bjørlykke, K., Karlsen, D. \& Saigal, G. 2002: Porosity preservation in reservoir sandstones due to grain-coating illite: a study of the Jurassic Garn Formation from the Kristin and Lavrans fields, offshore Mid-Norway. Marine Petroleum Geology 19, 767-781.

https://doi.org/10.1016/S0264-8172(02)00035-1.

Stuevold, L.M., Skogseid, J. \& Eldholm, O. 1992: Post-Cretaceous uplift events on the Vøring continental Margin. Geology 20, 919-922. https://doi.org/10.1130/0091-7613(1992)020<0919:PCUEOT>2.3.CO;2.

Sturt, B.A., Dalland, A. \& Mitchell, J.L. 1979: The age of the sub Mid-Jurassic tropical weathering profile on Andøya, and its implications for the Late Palaeozoic palaeotopography in the North Atlantic region. Geologische Rundschau 68, 523-542. https://doi.org/10.1007/BF01820805.

Surlyk, F. 1990: Timing, style and sedimentary evolution of Late Palaeozoic-Mesozoic extensional basins of East Greenland. In Hardman, R.F.P. \& Brooks, J. (eds.): Tectonic events responsible for Britain's oil and gas reserves, Geological Society of London Special Publication 55, pp. 107-155. https://doi.org/10.1144/GSL.SP.1990.055.01.05.

Surlyk, F. 1991: Sequence stratigraphy of the Jurassic-lowermost Cretaceous of East Greenland. American Association of Petroleum Geologists Bulletin 75, 1468-1488. https://doi.org/10.1306/0C9B296B-1710-11D7-8645000102C1865D.

Surlyk, F. 2003: The Jurassic of East Greenland: a sedimentary record of thermal subsidence, onset and culmination of rifting. In Ineson, J.R. \& Surlyk, F. (eds): The Jurassic of Denmark and Greenland, Geological Survey of Denmark and Greenland Bulletin 1, pp. 659-722. https://doi.org/10.34194/geusb.v1.4674. 
Surlyk, F. \& Clemmensen, L.B. 1983: Rift propagation and eustacy as controlling factors during Jurassic inshore and shelf sedimentation in northern East Greenland. Sedimentary Geology 34, 119-143. https://doi.org/10.1016/0037-0738(83)90083-0.

Surlyk, F. \& Noe-Nygaard, N. 2001: Cretaceous faulting and associated coarse-grained marine gravity flow sedimentation, Traill $\varnothing$, East Greenland. In Martinsen, O.J. \& Dreyer, T. (eds.): Sedimentary Environments Offshore Norway - Palaeozoic to Recent, Norwegian Petroleum Society Special Publication 10, pp. 293-319. https://doi.org/10.1016/S0928-8937(01)80019-9.

Surlyk, F., Clemmensen, L.B. \& Larsen, H.C. 1981: Post-Paleozoic evolution of the East Greenland continental margin. In Kerr, J.W \& Ferguson, A.J. (eds.): Geology of the North Greenland Atlantic Borderlands, Canadian Society Petroleum Geologists Memoir 7, pp. 611-645.

Surlyk, F., Hurst, J.M., Piasecki, S., Rolle, F., Scholle, P.A., Stemmerik, L. \& Thomsen, E. 1986: The Permian of the western margin of the Greenland Sea - a future exploration target. In Halbouty, M.E. (ed.): Future petroleum provinces of the world, American Association of Petroleum Geologists Memoir 40, pp. 629-659.

Svela, K.E., 2001: Sedimentary facies in the fluvial-dominated Are Formation as seen in the Åre 1 member in the Heidrun Field. In Martinsen, O. \& Dreyer, T. (eds): Sedimentary Environments Offshore Norway, Norwegian Petroleum Society, Special Publication 10, Elsevier, pp. 87-102.

https://doi.org/10.1016/S0928-8937(01)80010-2.

Swiecicki, T., Gibbs, P.B., Farrow, G.E. \& Coward, M.P. 1998: A tectonostratigraphic framework for the Mid-Norway region. Marine and Petroleum Geology 15, 245-276.

https://doi.org/10.1016/S0264-8172(97)00029-9.

Talwani, M. \& Eldholm, O. 1972: The continental margin off Norway: A Geophysical study. Geological Society of America Bulletin 83, 3375-3408. https://doi.org/10.1130/0016-7606(1972)83[3575:CMONAG]2.0.CO;2.

Talwani, M. \& Eldholm, O. 1977: Evolution of the Norwegian-Greenland Sea. Geological Society of America Bulletin 88, 969-999. https://doi.org/10.1130/0016-7606(1977)88<969:EOTNS>2.0.CO;2.

Theissen-Krah, S., Zastrozhnov, D., Abdelmalak, M.M., Schmid, D.W., Faleide, J.I., \& Gernigon, L. 2017: Tectonic evolution and extension at the Møre Margin - Offshore mid-Norway. Tectonophysics 721, 227-238. https://doi.org/10.1016/j.tecto.2017.09.009.

Torsvik, T.H. \& Cocks, L.M.R. 2005: Norway in space and time: A Centennial cavalcade. Norwegian Journal of Geology 85, 73-86.

Torsvik, T.H., Mosar, J. \& Eide, E.A. 2001: Cretaceous-Tertiary Geodynamics: A North Atlantic Exercise. Geophysical Journal International 146, 850-866. https://doi.org/10.1046/j.0956-540x.2001.01511.x.

Torsvik, T.H., Carlos, D., Mosar, J., Cocks, L.R.M. \& Malme, T.N. 2003: Global reconstructions and North Atlantic paleogeography 440 Ma to recent. In BATLAS, Mid Norway plate reconstruction atlas with global and Atlantic perspectives, Geological Survey of Norway.

Tsikalas, F., Faleide, J.I. \& Eldholm, O. 2001: Lateral variations in tectono-magmatic style along the Lofoten-Vesterålen volcanic margin off Norway. Marine and Petroleum Geology 18, 807-832. https://doi.org/10.1016/S0264-8172(01)00030-7. 
Tsikalas, F., Eldholm, O. \& Faleide, J.I. 2005: Crustal structure of the Lofoten-Vesterålen continental margin off Norway. Tectonophysics 404, 151-174. https://doi.org/10.1016/j.tecto.2005.04.002.

Tsikalas, F., Faleide, J.I. \& Kalac, A. 2019: New insights into Cretaceous-Cenozoic tectonostratigraphic evolution of the southern Lofoten margin, offshore Norway. Marine and Petroleum Geology 110, 832-855. https://doi.org/10.1016/j.marpetgeo.2019.07.025.

Valle, P., Færseth, R.B. \& Fossen, H. 2002: Devonian-Triassic brittle deformation based on dyke geometry and fault kinematics in the Sunnhordland region, SW Norway. Norwegian Journal of Geology 82, 3-17.

Vergara, L., Wreglesworth, I., Trayfoot, M. \& Richardsen, G. 2001: The distribution of Cretaceous and Paleocene deep-water reservoirs in the Norwegian basins. Petroleum Geoscience 7, 395-408. https://doi.org/10.1144/petgeo.7.4.395.

Vigran, J.O., Stemmerik, L., \& Piasecki, S. 1999: Stratigraphy and depositional evolution of the uppermost Devonian-Carboniferous (Tournaisian-Westphalian) non-marine deposits in north-east Greenland: Palynology 23, 115-152. https://doi.org/10.1080/01916122.1999.9989525.

Voss, M. \& Jokat, W. 2009: From Devonian extensional collapse to Early Eocene continental break-up: An extended transect of the Keiser Franz Joseph Fjord of the East Greenland. Geophysical Journal International 177, 743-754. https://doi.org/10.1111/j.1365-246X.2008.04076.x.

Vågnes, E., Gabrielsen, R.H. \& Haremo, P. 1998: Late Cretaceous-Cenozoic intraplate deformation at the Norwegian continental shelf: timing, magnitude and regional implications. Tectonophysics 300, 29-46. https://doi.org/10.1016/S0040-1951(98)00232-7.

Whitham, A.G., Price, S.P., Koraini, A.M. \& Kelly, S.R.A. 1999: Cretaceous (post-Valanginian) sedimentation and rift events in NE Greenland. In Fleet, A.J. \& Boldy, S.A. (eds.): Petroleum Geology of Northwest Europe: Proceedings of the 5th Conference, pp. 325-336. https://doi.org/10.1144/0050325.

Wignal, P.B. \& Twitchett, R.J. 2002: Permian-Triassic sedimentology of Jameson Land, East Greenland: Incised submarine channels in an anoxic basin. Journal of the Geological Society of London 159, 691-703. https://doi.org/10.1144/0016-764900-120.

Wilson, R.W., McCaffrey, K.J.W., Holdsworth, R.E., Imber, J., Jones, R.R., Welbon, A.I-F. \& Roberts, D. 2006: Complex fault patterns, transtension and structural segmentation of the Lofoten Ridge, Norwegian margin; using digital mapping to link onshore and offshore geology. Tectonics 25, 1-28.

Wilson, P., Elliott, G.M., Gawthorpe, R.L., Jackson, C.A.-L., Michelsen, L. \& Sharp, I.R. 2013: Geometry and segmentation of an evaporite-detached normal fault array: 3D seismic analysis of the southern Bremstein Fault Complex, offshore mid-Norway. Journal of Structural Geology 51, 74-91. https://doi.org/10.1016/j.jsg.2013.03.005.

Wilson, P., Elliott, G.M., Gawthorpe, R.L., Jackson, C.A-L., Michelsen, L. \& Sharp, I.R. 2015: Lateral variation in structural style along an evaporite-influenced rift fault system in the Halten Terrace, Norway: Influence of basement structure and evaporite facies. Journal of Structural Geology 79, 110-123. https://doi.org/10.1016/j.jsg.2015.08.002. 
Withjack, M.O., Meisling, K.E. \& Russel, L.R. 1989: Forced folding and basement-detached normal faulting in the Haltenbanken area, offshore Norway. In Tankard, A.J, \& Balkwill, H.R. (eds.): Extensional tectonics and stratigraphy of the North Atlantic Margins, American Association of Petroleum Geologists, Memoir 46, pp. 567-575.

Withjack, M.O., Schlische, R.W. \& Olsen, P.E. 2002: Rift basin structure and its influence on sedimentary systems. In Renaut R.W. \& Ashley G.M. (eds.): Sedimentation in Continental Rifts, Special Publications 73, Society for Sedimentary Geology. https://doi.org/10.2110/pec.02.73.0057.

Wood, R.J., Edrich, S.P. \& Hutchison, I. 1989: Influence of North Atlantic tectonics in the large-scale uplift of the Stappen High and Loppa High, Western Barents Sea. In Tankard, A.J. \& Balkwill, H.R. (eds.): Extensional tectonics and Stratigraphy of the North Atlantic Margins, American Association of Petroleum Geologists, Memoir 46, pp. 559-566.

Young, R. 1992: Restauration of a regional profile across the Magnus Field in the northern North Sea. In Larsen, R.M., Brekke, H., Larsen, B.T. \& Tallerås, E. (eds.): Structural and Tectonic Modelling and its Application to Petroleum Geology, Norwegian Petroleum Society Special Publication 1, pp. 221-229. https://doi.org/10.1016/B978-0-444-88607-1.50019-X.

Zastrozhnov, D., Gernigon, L., Gogin, I., Planke, S., Faleide, J.I., Eide, S. \& Myklebust, R. 2018: Cretaceous-Paleocene evolution of the northern Vøring Basin (Offshore Mid-Norway): Results from integrated geological and geophysical study. Tectonics 37, 497-528.

https://doi.org/10.1002/2017TC004655.

Zastrozhnov, D., Gernigon, L., Gogin, I., Planke, S., Abdelmalak, M.M., Polteau, S., Faleide, J.I., Manton, B. \& Myklebust, R. 2020: Regional structure and polyphased Cretaceous-Paleocene rift and basin development of the mid-Norwegian volcanic passive margin. Marine and Petroleum Geology 115. https://doi.org/10.1016/j.marpetgeo.2020.104269.

Ziegler, P.A. 1988: Evolution of the Artic-North Atlantic and Western Tethys. American Association of Petroleum Geologists, Memoir 43.

Ziegler, P.A. 1989: Evolution of the North Atlantic - an overview. American Association of Petroleum Geologists 46, 111-129.

Ziegler, P.A. 1990: Geological Atlas of Western and Central Europe, $2^{\text {nd }}$ ed., Shell International Petroleum Maatschappij B.V., Geological Society of London, Bath.

$\varnothing$ stvedt. O.J., Blystad, P. \& Magnus, C. 2005: Exploration history on the Norwegian Continental Shelf, 1990-2002: expectations and results. In Doré, A.G. \& Vining, B.A. (eds.): Petroleum Geology: North West Europe and Global Perspectives - Proceedings of the 6th Petroleum Geology Conference, Geological Society, London, pp. 55-62. https://doi.org/10.1144/0060055. 